\title{
Ground-Water Quality in Northeastern St. Joseph County, Indiana
}

By JOSEPH M. FENELON, E. RANDALL BAYLESS, and LEE R. WATSON

Prepared in cooperation with the INDIANA DEPARTMENT OF NATURAL RESOURCES, Division of Water

U.S. GEOLOGICAL SURVEY Water-Resources Investigations Report 95-4092

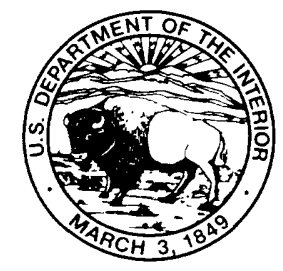

Indianapolis, Indiana 1995 


\title{
U.S. DEPARTMENT OF THE INTERIOR BRUCE BABBITT, Secretary
}

\author{
U.S. GEOLOGICAL SURVEY \\ Gordon P. Eaton, Director
}

For additional information, write to:

District Chief

U.S. Geological Survey

Water Resources Division

5957 Lakeside Boulevard

Indianapolis, IN 46278-1996
Copies of this report can be purchased from:

U.S. Geological Survey

Earth Science Information Center

Open-File Reports Section

Box 25286, MS 517

Denver Federal Center

Denver, CO 80225 


\section{CONTENTS}

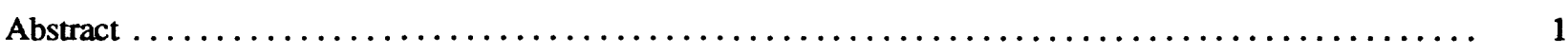

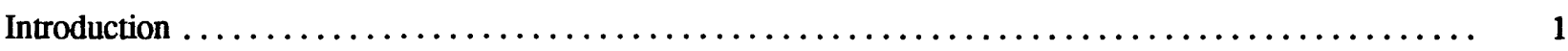

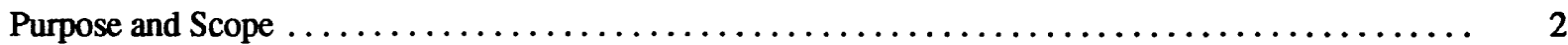

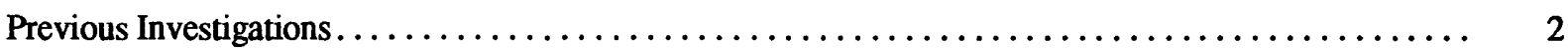

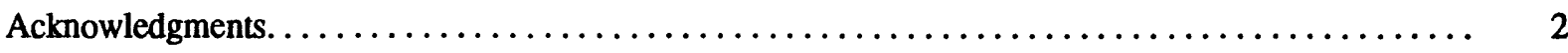

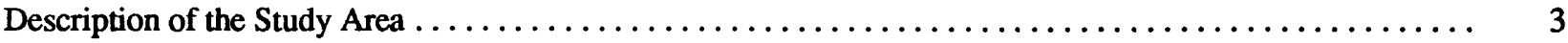

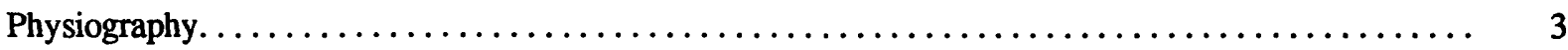

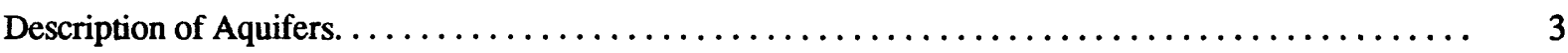

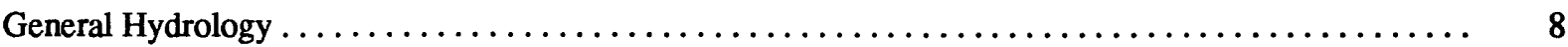

Methods ...................................................... 10

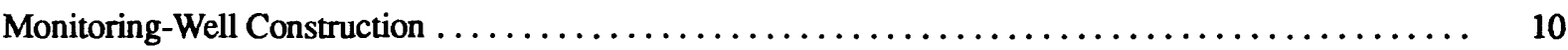

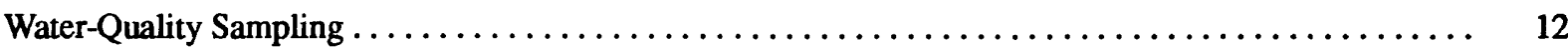

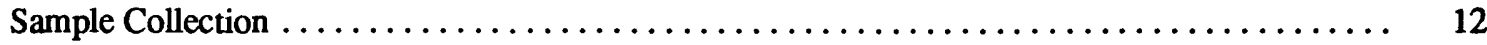

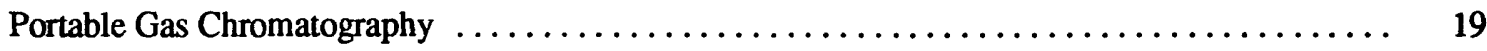

Enzyme-Linked Immunosorbent Assay. . . . . . . .

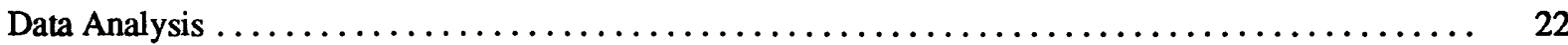

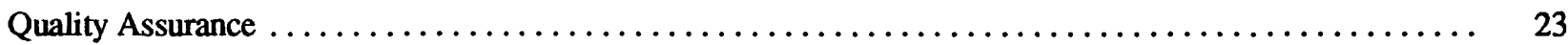

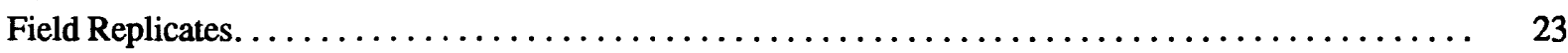

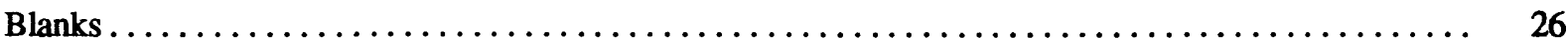

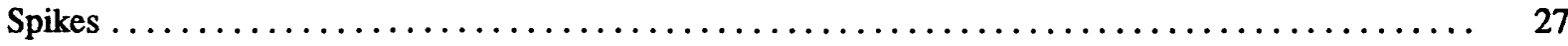

Additional Quality-Assurance Steps. ................................ 27

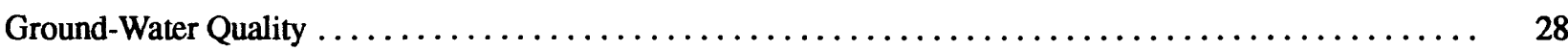

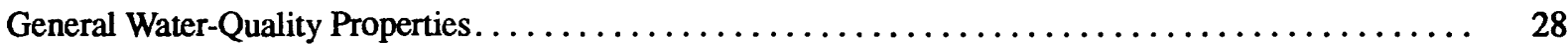

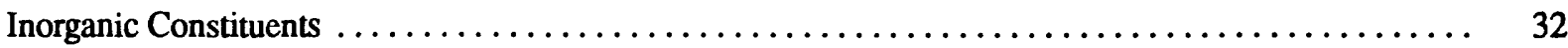

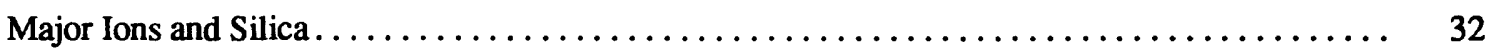

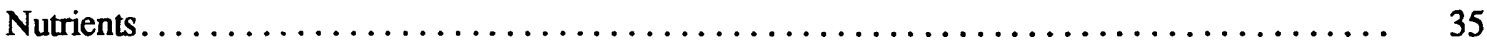

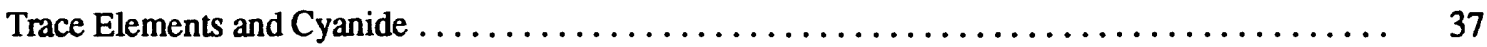

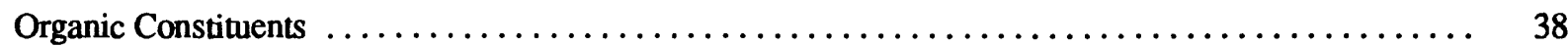

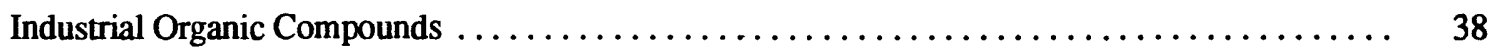

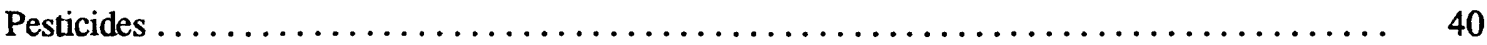

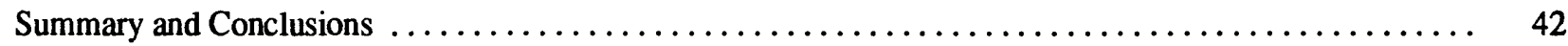

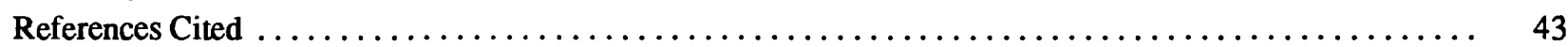

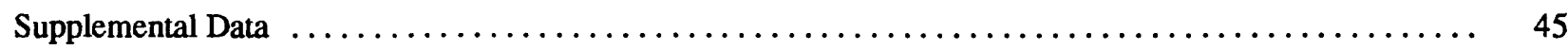

\section{FIGURES}

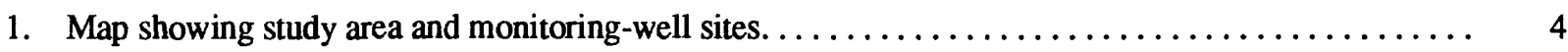

2. Map showing distribution of aquifer systems in northeastern St. Joseph County, Indiana ......... 5

3. Generalized hydrogeologic sections through northeastem St. Joseph County, Indiana ......... 6

4. Map showing thickness of confining unit separating the shallow aquifer from the deep aquifer in the St. Joseph aquifer system, northeastern St. Joseph County, Indiana 


\section{CONTENTS}

\section{FIGURES—CONTINUED}

5. Map showing general configuration and altitude of the potentiometric surface in the unconsolidated deposits, northeastern St. Joseph County, Indiana $\ldots \ldots \ldots \ldots \ldots \ldots \ldots \ldots .9$

6. Trilinear diagram showing distribution of major ions in the shallow aquifer and the deep aquifer,

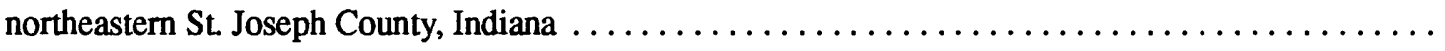

7. Graph showing relation of sodium and chloride concentrations to land use and depth, northeastern St. Joseph County, Indiana . . . . . . . . . . . . . . . . . . . . . . . . . . . . . .

8. Box plots showing relations of concentrations of nitrate plus nitrite and ammonia to well depth,

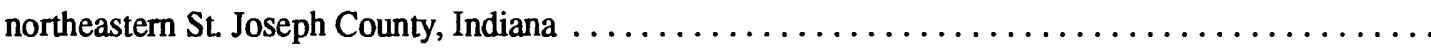

9. Box plots showing relations of concentrations of selected trace elements to well depth, northeastem

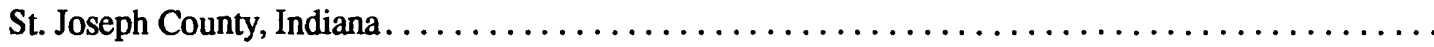

\section{TABLES}

1. Characteristics of monitoring wells in northeastern St. Joseph County, Indiana. . . . . . . . . .

2. Collection, preparation, and preservation requirements for ground-water samples submitted for

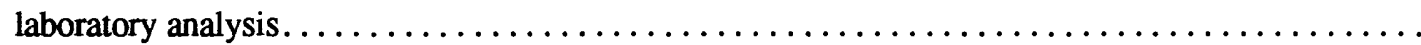

3. List of inorganic constituents and properties determined in ground water in northeastern St. Joseph County, Indiana, and corresponding parameter codes, reporting limits, and U.S. Environmental Protection Agency Drinking Water Regulations and Health Advisories ........

4. Base/neutral- and acid-extractable semivolatile organic compounds, polychlorinated biphenyls, and polychlorinated naphthalenes determined in ground water in northeastern St. Joseph County, Indiana, and corresponding parameter codes, reporting limits, and U.S. Environmental Protection Agency Drinking Water Regulations and Health Advisories . . . . . . . . . . . . .

5. Pesticides determined in ground water in northeastern St. Joseph County, Indiana, and corresponding parameter codes, reporting limits, and U.S. Environmental Protection Agency Drinking Water Regulations and Health Advisories . . . . . . . . . . . . . . . . . . . . .

6. Volatile organic compounds determined in ground water in northeastern St. Joseph County, Indiana, and corresponding parameter codes, reporting limits, and U.S. Environmental Protection Agency Drinking Water Regulations and Health Advisories .

7. Quality-assurance data for general water-quality properties and inorganic constituents determined in ground water, northeastern St. Joseph County, Indiana $\ldots \ldots \ldots \ldots \ldots \ldots \ldots \ldots$

8. Statistical summary of general water-quality properties and concentrations of inorganic constituents in water from 30 wells in northeastern St. Joseph County, Indiana, sampled in May 1992 . . . . . . .

9. Summary of results from Wilcoxon-Mann-Whitney rank sum test to determine differences in selected constituents between the shallow aquifer and the deep aquifer, northeastern St. Joseph

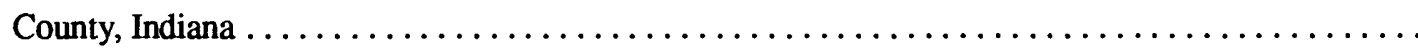

10. Pesticide concentrations in water from 30 wells in northeastern St. Joseph County, Indiana,

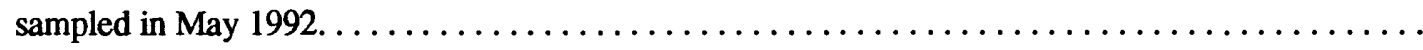

11. Data for general water-quality properties and inorganic constituents in water from 30 wells in northeastern St. Joseph County, Indiana, May 1992 


\begin{tabular}{rll}
\hline Multiply & By & To obtain \\
\hline inch (in.) & 25.4 & millimeter \\
foot (ft) & 0.3048 & meter \\
foot per day (ft/d) & 0.3048 & meter per day \\
mile (mi) & 1.609 & kilometer \\
square mile (mi $\left.{ }^{2}\right)$ & 2.590 & square kilometer \\
gallon (gal) & 3.785 & liter \\
gallon per minute (gal/min) & 3.785 & liter per minute \\
million gallons per day (Mgal/d) & 0.04381 & cubic meter per second \\
Sodium concentration, in milligrams & 0.04350 & Sodium concentration in \\
per liter $(\mathrm{mg} / \mathrm{L})$ & & milliequivalents per liter $(\mathrm{meq} / \mathrm{L})$ \\
per liter $(\mathrm{mg} / \mathrm{L})$ & 0.02821 & Chloride concentration, in \\
Chloride concentration, in milligrams & & milliequivalents per liter \\
\hline
\end{tabular}

Temperature in degrees Celsius $\left({ }^{\circ} \mathrm{C}\right)$ can be converted to degrees Fahrenheit $\left({ }^{\circ} \mathrm{F}\right)$ as follows:

$$
{ }^{\circ} \mathrm{F}=1.8 \times{ }^{\circ} \mathrm{C}+32
$$

Sea level: In this report, "sea level" refers to the National Geodetic Vertical Datum of 1929 (NGVD of 1929)-a geodetic datum derived from a general adjustment of the first-order level nets of the United States and Canada, formerly called Sea Level Datum of 1929.

\begin{abstract}
Abbreviated water-quality units used in this report: Chemical concentrations and water temperature are given in metric units. Chemical concentration is given in milligrams per liter $(\mathrm{mg} / \mathrm{L})$, micrograms per liter $(\mu \mathrm{g} / \mathrm{L})$, or milliequivalents per liter (meq/L). Milligrams per liter is a unit expressing the concentration of chemical constituents in solution as weight (milligrams) of solute per unit volume (liter) of water. One thousand micrograms per liter is equivalent to one milligram per liter. For concentrations less than $7,000 \mathrm{mg} / \mathrm{L}$, the numerical value is the same as for concentrations in parts per million. Concentration in milliequivalents per liter is computed by multiplying the concentration in milligrams per liter by the reciprocal of the atomic weight of the element of interest. Factors to convert chloride and sodium concentrations from concentrations in milligrams per liter to concentrations in milliequivalents per liter are included in the table of conversion factors included with this part of the report.
\end{abstract}

Specific conductance of water is expressed in microsiemens per centimeter at 25 degrees Celsius $(\mu \mathrm{S} / \mathrm{cm})$. This unit is equivalent to micromhos per centimeter at 25 degrees Celsius $(\mu \mathrm{mho} / \mathrm{cm})$, formerly used by the U.S. Geological Survey.

Volumes of sample are given in liters (L). 


\section{CONVERSION FACTORS, VERTICAL DATUM, AND ABBREVIATIONS-Continued}

Other abbreviations used in this report:

\begin{tabular}{|c|c|}
\hline Abbreviation & Description \\
\hline $\mathrm{CaCO}_{3}$ & Calcium carbonate \\
\hline $\mathrm{eV}$ & Electron volt \\
\hline pH & Negative log base-10 of the hydrogen-ion activity \\
\hline DNRA & Dissimilatory nitrate reduction to ammonium \\
\hline ELISA & Enzyme-linked immunosorbent assay \\
\hline GC/MS & Gas chromatography/mass spectroscopy \\
\hline MBAS & Methylene-blue-active substances \\
\hline PGC & Portable gas chromatograph \\
\hline TDS-calc & $\begin{array}{l}\text { Total dissolved solids, calculated by summing the mass } \\
\text { all dissolved constituents except bicarbonate, whicl } \\
\text { multiplied by } 0.4917 \text { and then added }\end{array}$ \\
\hline TDS-res & $\begin{array}{l}\text { Total dissolved solids, the measured mass of residue up } \\
\text { evaporation of a water sample }\end{array}$ \\
\hline HA-c & $\begin{array}{l}\text { Health Advisory for a carcinogen corresponding to a } \\
\text { cancer-risk probability of } 1 \text { in } 10,000\end{array}$ \\
\hline HA-1 & $\begin{array}{l}\text { Health Advisory for a compound corresponding to an } \\
\text { adult lifetime exposure concentration }\end{array}$ \\
\hline MCL & Maximum Contaminant Level \\
\hline PMCL & Proposed Maximum Contaminant Level \\
\hline SMCL & Secondary Maximum Contaminant Level \\
\hline QA & Quality assurance \\
\hline QA/QC & Quality assurance/quality control \\
\hline IDNR & Indiana Department of Natural Resources \\
\hline NWQL & $\begin{array}{l}\text { U.S. Geological Survey, National Water Quality } \\
\text { Laboratory, Arvada, Colo. }\end{array}$ \\
\hline USEPA & U.S. Environmental Protection Agency \\
\hline USGS & U.S. Geological Survey \\
\hline
\end{tabular}




\title{
Ground-Water Quality in Northeastern St. Joseph County, Indiana
}

\author{
By Joseph M. Feneion, E. Randall Bayless, and Lee R. Watson
}

\section{Abstract}

This report describes the ground-water quality of a 220 -square-mile area in northeastern St. Joseph County, Indiana. Ground-water samples were collected from 30 monitoring wells at 20 sites during May 1992; the wells were screened in either a shallow or a deep sand and gravel aquifer. Samples were analyzed for general water-quality properties, nutrients, major ions, trace elements, industrial organic compounds, and pesticides.

In general, the ground water is a slightly basic, very hard calcium bicarbonate water with a median dissolved-solids concentration of 310 milligrams per liter. The only constituent to exceed a U.S. Environmental Protection Agency Maximum Contaminant Level in the water samples was nitrate (which was exceeded in water samples from two wells).

Concentrations of methylene-blueactive substances (detergent additives), chloride, and nitrate plus nitrite in the shallow aquifer were significantly higher (at the 0.05 probability level) than in the deep aquifer. The higher concentrations of these constituents in the shallow aquifer may be attributable to human activities. Concentrations of silica, ammonia, arsenic, antimony, barium, iron, and manganese in the deep aquifer were significantly higher than in the shallow aquifer, with the exception of ammonia, most or all of these constituents are probably from natural sources.
No industrial organic compounds were detected in the water samples. Four pesticides-alachlor, carbofuran, metolachlor, and triazines-were detected in water samples; the highest pesticide concentration in a water sample was 1.0 microgram per liter of alachlor.

\section{INTRODUCTION}

Ground water is the primary source of drinking water in northeastern St. Joseph County, Ind. Use of this resource was forecast to double between 1980 and 2000 (Clendenon and Beaty, 1987). Most of the water in this area is obtained from unconsolidated sand and gravel deposits of the St. Joseph aquifer system, the only sole-source aquifer designated by the U.S. Environmental Protection Agency (USEPA) in Indiana ${ }^{1}$. The amount of ground water in the aquifer is vast. In general, the water quality is adequate for domestic use, but volatile organic compounds and nitrate have been detected at some sites (Clendenon and Beaty, 1987). As the ground-water use increases, the possibility of ground-water contamination and

\footnotetext{
${ }^{1}$ A sole-source aquifer is designated by the USEPA under Section 1424 (e) of the Safe Drinking Water Act of 1974 . The aquifer must be the primary source of water to most (more than 50 percent) of the nearby residents. Federally funded projects overlying a Federally designated sole-source aquifer are evaluated for their potential to contaminate the aquifer; any potential adverse effects on the aquifer must be corrected before the project can be Federally funded (Indiana Department of Environmental Management, 1989, p. 290-94).
} 
resource depletion increases. Changing rates and locations of significant ground-water withdrawals could alter the flow paths of ground and surface water and may draw water of undesirable quality from contaminated areas or the underlying shale bedrock into contact with residential and municipal wells or may cause shallow wells to go dry. Concern for the effect of increased ground-water production and the susceptibility of the aquifer to contamination prompted a comprehensive groundwater assessment by the U.S. Geological Survey (USGS), in cooperation with the Indiana Department of Natural Resources (IDNR).

\section{Purpose and Scope}

This report describes the general groundwater quality of a $220-\mathrm{mi}^{2}$ area in northeastern St. Joseph County, Ind. Ground-water samples were collected from 30 monitoring wells at 20 sites during May 1992; the wells are screened in either a shallow or a deep sand and gravel aquifer. All but one of the wells are in the St. Joseph aquifer system in the northem and most populated part of the study area and in the most productive parts of the aquifers. The monitoring wells were sited to characterize the general ground-water quality, particularly in areas that may be future sites for public-supply well fields or areas where rapid residential expansions will result in increased construction of private wells. Documented industrially contaminated sites (Michiana Area Council of Governments, 1989) were not sampled. Water samples were analyzed for general waterquality properties, nutrients, major ions, trace elements, industrial organic compounds, and pesticides. Industrial organic compounds consist of base/neutral- and acid-extractable semivolatile organic compounds, volatile organic compounds, polychlorinated biphenyls (PCB's), and polychlorinated naphthalenes (PCN's). Analyte concentrations in water are compared by screen depth of the sampled well and land-use type to evaluate the potential effects of these factors on water quality. Analyte concentrations also are compared to USEPA Drinking Water Regulations and Health Advisories as a basis for describing the quality of the water.

\section{Previous Investigations}

The hydrogeology of the unconsolidated aquifers of northeastern St. Joseph County has been described in several reports by State and Federal agencies (Fowler, 1994; Clendenon and Beaty, 1987; Reussow and Rohne, 1975; Hunn and Rosenshein, 1969; Pettijohn, 1968; and Klaer and Stallman, 1948). These reports describe and name aquifers; included are estimates of recharge and discharge rates, transmissivities, and storage coefficients and the development potential of the aquifers. In investigations by Peters and Renn (1988), Peters (1987), and Marie (1975), hydraulic properties of the unconsolidated aquifers were examined by use of various analytical and numerical models.

Results from approximately 500 chemical water-quality analyses of the ground water in St. Joseph County are included in Rosenshein and Hunn (1962) and Klaer and Stallman (1948); almost half of the analyses are from ground water in the study area. The analyses are primarily for temperature, alkalinity, sulfate, chloride, hardness, and iron. More than 400 ground-water analyses for major ions (calcium, magnesium, sodium, potassium, chloride, and sulfate) and alkalinity, nitrate, fluoride, $\mathrm{pH}$, iron, and manganese for the St. Joseph River Basin are provided in Clendenon and Beaty (1987); 62 of the analyses are from ground water in the study area.

Brief discussions of the ground-water quality in the study area are included in Reussow and Rohne (1975), Hunn and Rosenshein (1969), Pettijohn (1968), and Klaer and Stallman (1948). A more comprehensive discussion of water quality in the study area is given in Clendenon and Beaty (1987).

\section{Acknowledgments}

The authors received assistance from many people during this study. The Indiana Department of Natural Resources, Division of Water, provided data and vital input. The citizens and officials of South Bend, Mishawaka, and northeastern St. Joseph County allowed access to their properties for well installation and data collection. 
DESCRIPTION OF THE STUDY AREA

The study area is in northeastern St. Joseph County and is bounded by the St. Joseph CountyElkhart County boundary on the east, the IndianaMichigan State line on the north, and the St. Joseph River drainage divide on the south and the west (fig. 1). The study area is entirely within the St. Joseph River drainage basin; however, none of the boundaries necessarily corresponds to ground-water basin boundaries. Two metropolitan areas (South Bend and Mishawaka) and several smaller communities (including Granger, Osceola, and Roseland) are in the study area. Approximately 210,000 people lived within the study area in 1990 (Clendenon and Beaty, 1987, Appendix 1).

\section{Physiography}

The study area lies entirely within two physiographic units: the Kankakee Outwash and Lacustrine Plain and the Steuben Morainal Lake Area (Malott, 1922). The northern two-thirds of the study area lies within the Kankakee Outwash and Lacustrine Plain-a large outwash plain formed by glacial rivers during various glacial advances and retreats through northern Indiana (Malott, 1922). The plain is characterized by a gently undulating land surface with a descent of approximately 15 to $30 \mathrm{ft}$ into the St. Joseph River Valley. Elevations on the outwash plain range from about 680 to $800 \mathrm{ft}$ above sea level.

The Steuben Morainal Lake Area, which covers the southern one-third of the study area, is a gently undulating till plain within the study area. Local relief is approximately $170 \mathrm{ft}$ along the boundary between the Kankakee Outwash and Lacustrine Plain and the Steuben Morainal Lake Area. Elevations are as high as $920 \mathrm{ft}$ above sea level in the Steuben Morainal Lake Area.

\section{Description of Aquifers}

The thickness of unconsolidated deposits in the study area ranges from less than $30 \mathrm{ft}$ in the Mishawaka area (Clendenon and Beaty, 1987) to more than $200 \mathrm{ft}$ in areas away from the St. Joseph
River Valley. Most of the deposits consist of Wisconsin-age outwash, till, and lake sediments. These deposits in northeastern St. Joseph County (fig. 2) form three aquifer systems - the St. Joseph, the Hilltop, and the Nappanee - that were identified and named by Clendenon and Beaty (1987).

The St. Joseph aquifer system, in the northern half of the study area, is primarily outwash deposits that are composed of sand and gravel. The outwash deposits are locally separated by a clayrich unit (fig. 3 ) that is composed of till or lake deposits (Clendenon and Beaty, 1987). In this report, sand and gravel deposits above the clay-rich unit are referred to as the "shallow aquifer"; sand and gravel deposits below the unit are referred to as the "deep aquifer." The clay-rich unit in the St. Joseph aquifer system ranges in thickness from 0 to about $100 \mathrm{ft}$ but is commonly 10 to $75 \mathrm{ft}$ (fig. 4). The bottom of the clay-rich unit is typically 30 to $120 \mathrm{ft}$ below land surface. Where the clay-rich unit is absent, the sand and gravel is as much as $200 \mathrm{ft}$ thick. Where the clay-rich unit is present, typical sand and gravel thicknesses range from 20 to $80 \mathrm{ft}$ in the shallow aquifer and 40 to $100 \mathrm{ft}$ in the deep aquifer. Rates of groundwater withdrawal from the St. Joseph aquifer system reportedly range from 100 to $1,500 \mathrm{gal} / \mathrm{min}$ (Clendenon and Beaty, 1987). Horizontal hydraulic conductivity in the sand and gravel ranges from 280 to $600 \mathrm{ft} / \mathrm{d}$ (Peters, 1987), whereas vertical hydraulic conductivity in the clay-rich unit ranges from 0.04 to $0.21 \mathrm{ft} / \mathrm{d}$ (Lindgren and others, 1985).

The Hilltop aquifer system is in the south western part of the study area, whereas the Nappanee aquifer system is primarily in the southeastern part of the study area (fig. 2). An escarpment of 80 to $200 \mathrm{ft}$ separates the topographically higher Hilltop and Nappanee aquifer systems from the St. Joseph aquifer system. The Hilltop and Nappanee aquifer systems underlie the physiographic unit called the Steuben Morainal Lake Area. The Hilltop aquifer system consists of sand and gravel deposits overlain by 5 to $50 \mathrm{ft}$ of clayrich till (Clendenon and Beaty, 1987). Pumping rates in the Hilltop aquifer system range from 


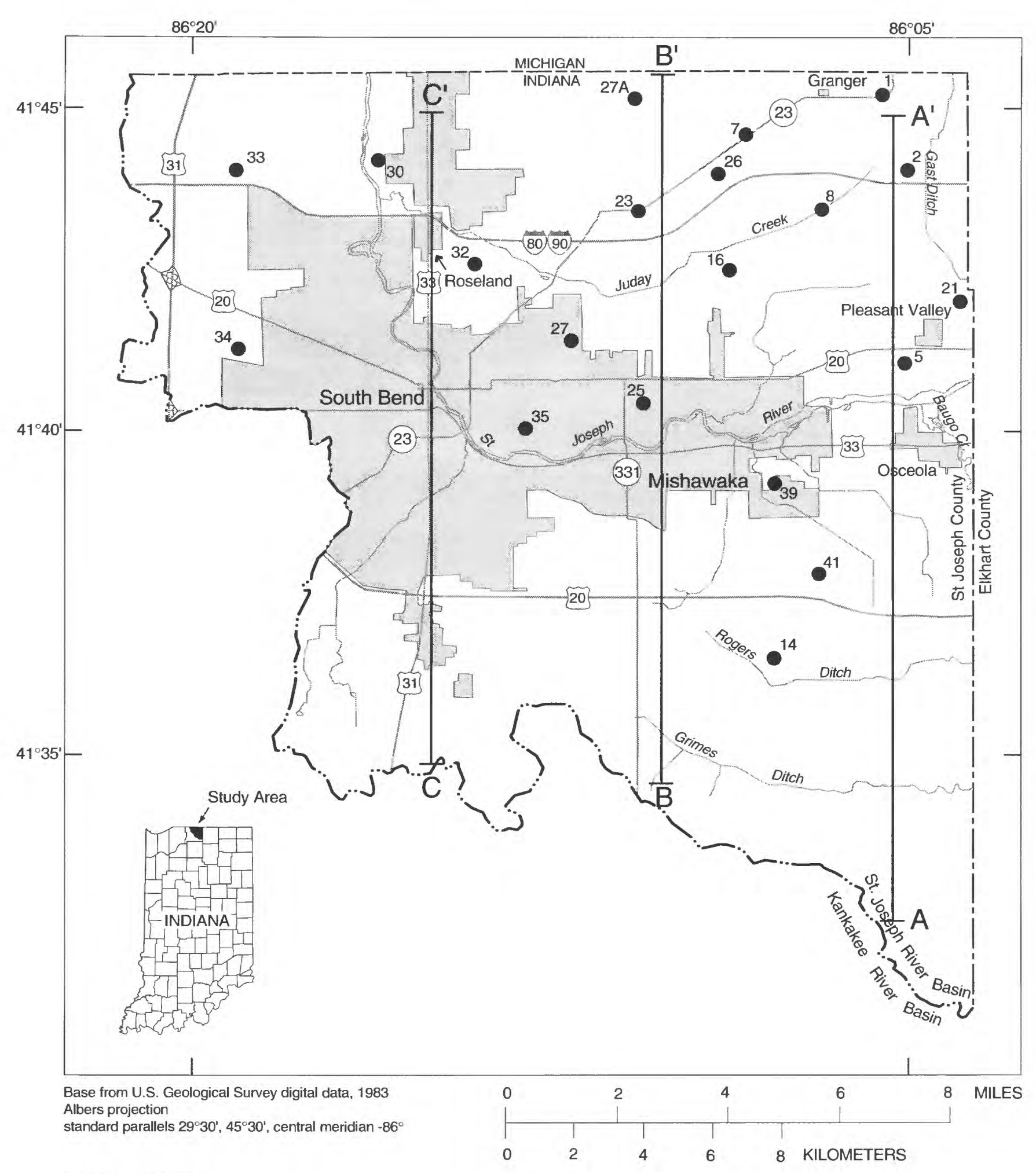

\section{EXPLANATION}

$A \longmapsto A^{\prime} \quad$ Trace of hydrogeologic section (sections shown in figure 3)

-... St. Joseph River drainage divide

22 Well site and identifier

Figure 1. Study area and monitoring-well sites. 


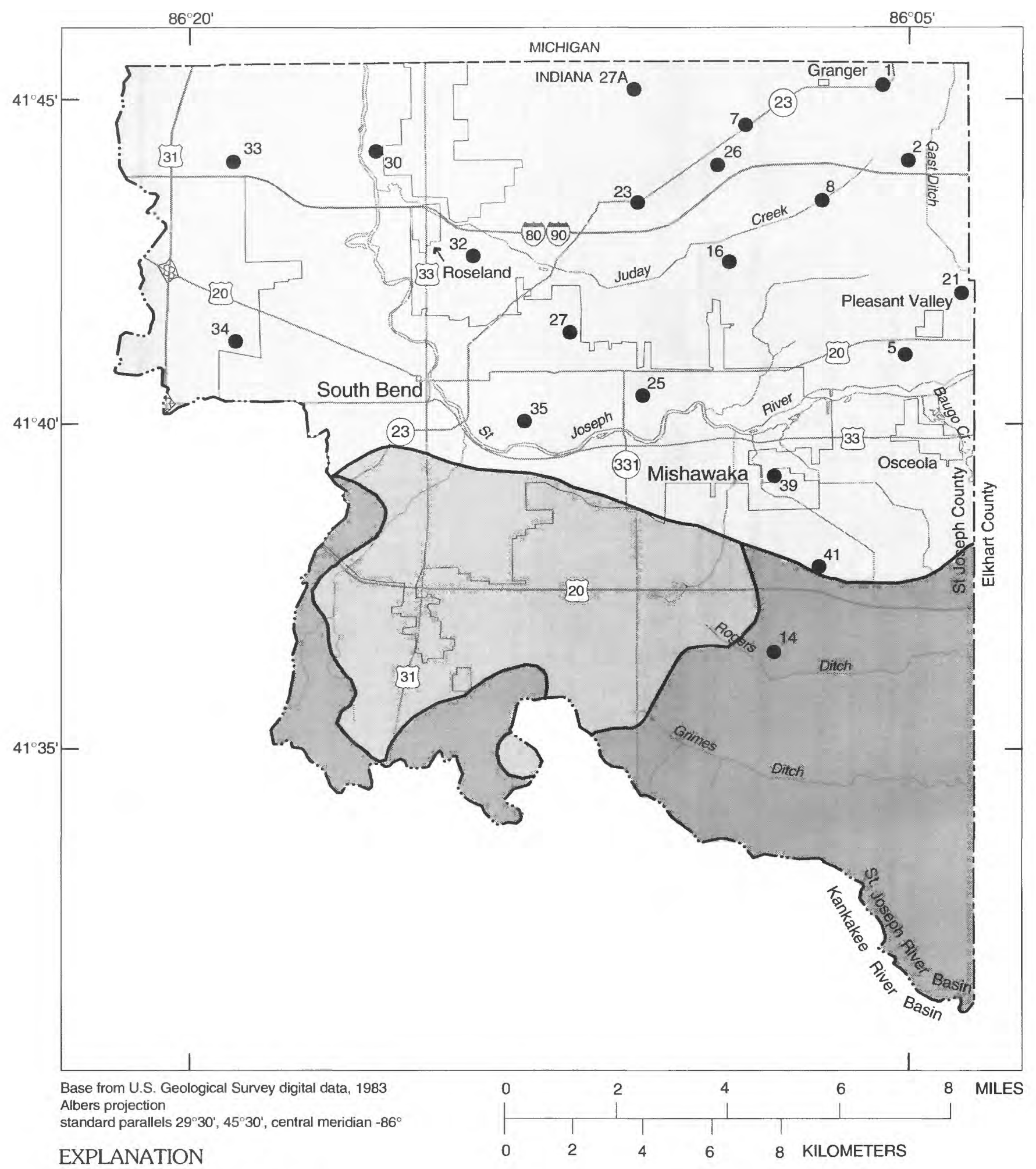

\section{EXPLANATION}

St. Joseph aquifer system

Hilltop aquifer system

Nappanee aquifer system

—..- St. Joseph River drainage divide

22 Well site and identifier

Figure 2. Distribution of aquifer systems in northeastern St. Joseph County, Indiana (modified from Clendenon and Beaty, 1987, pl. 2). 

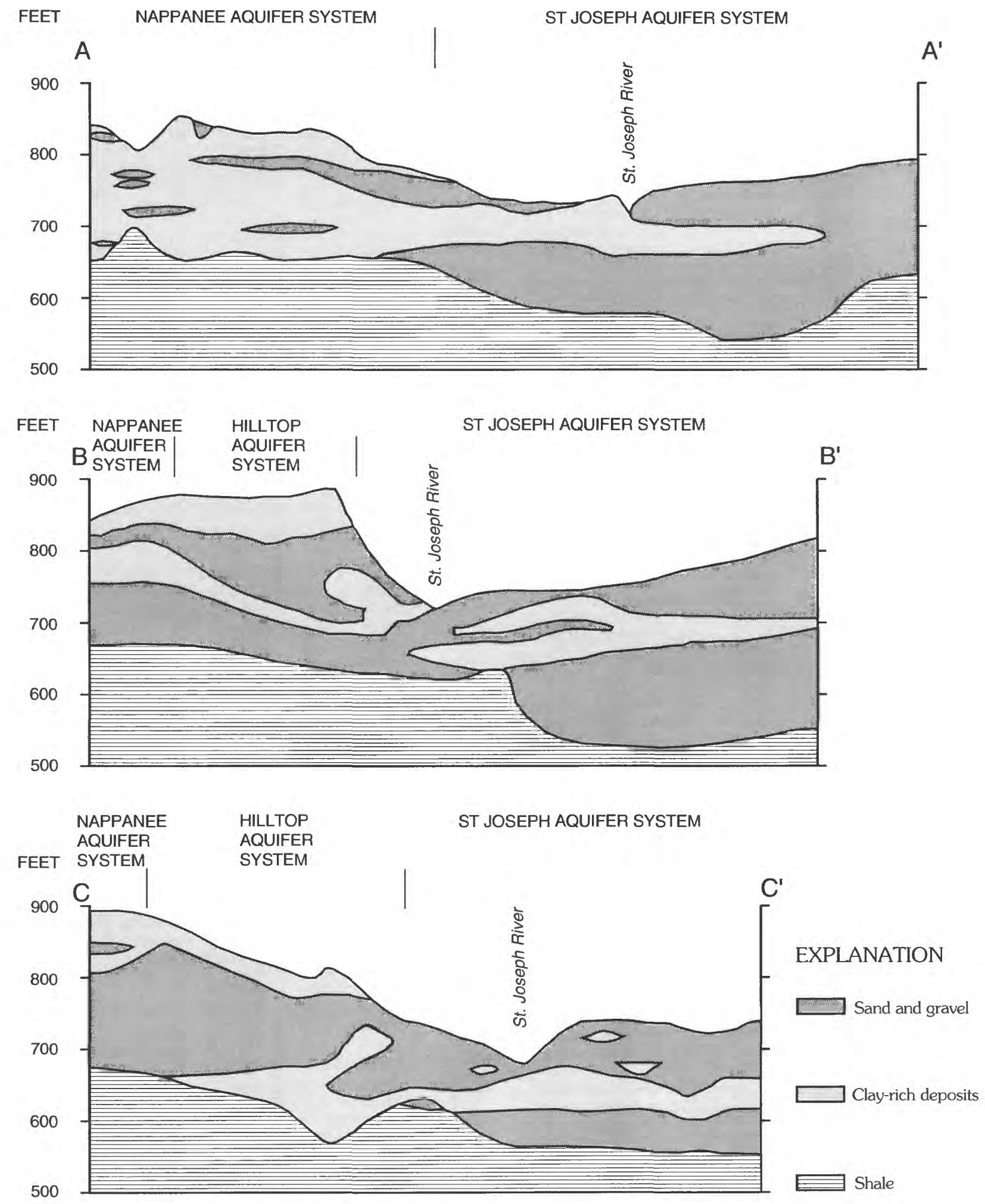

VERTICAL SCALE IS GREATLY EXAGGERATED

Figure 3. Generalized hydrogeologic sections through northeastern St. Joseph County, Indiana (traces of sections are shown in fig. 1).

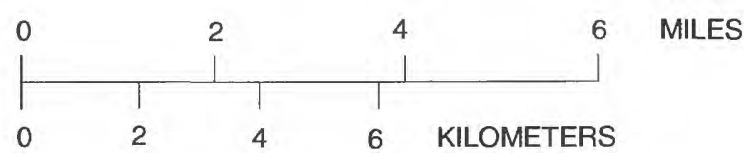

6 Ground-Water Quality in Northeastern St. Joseph County, Indiana 


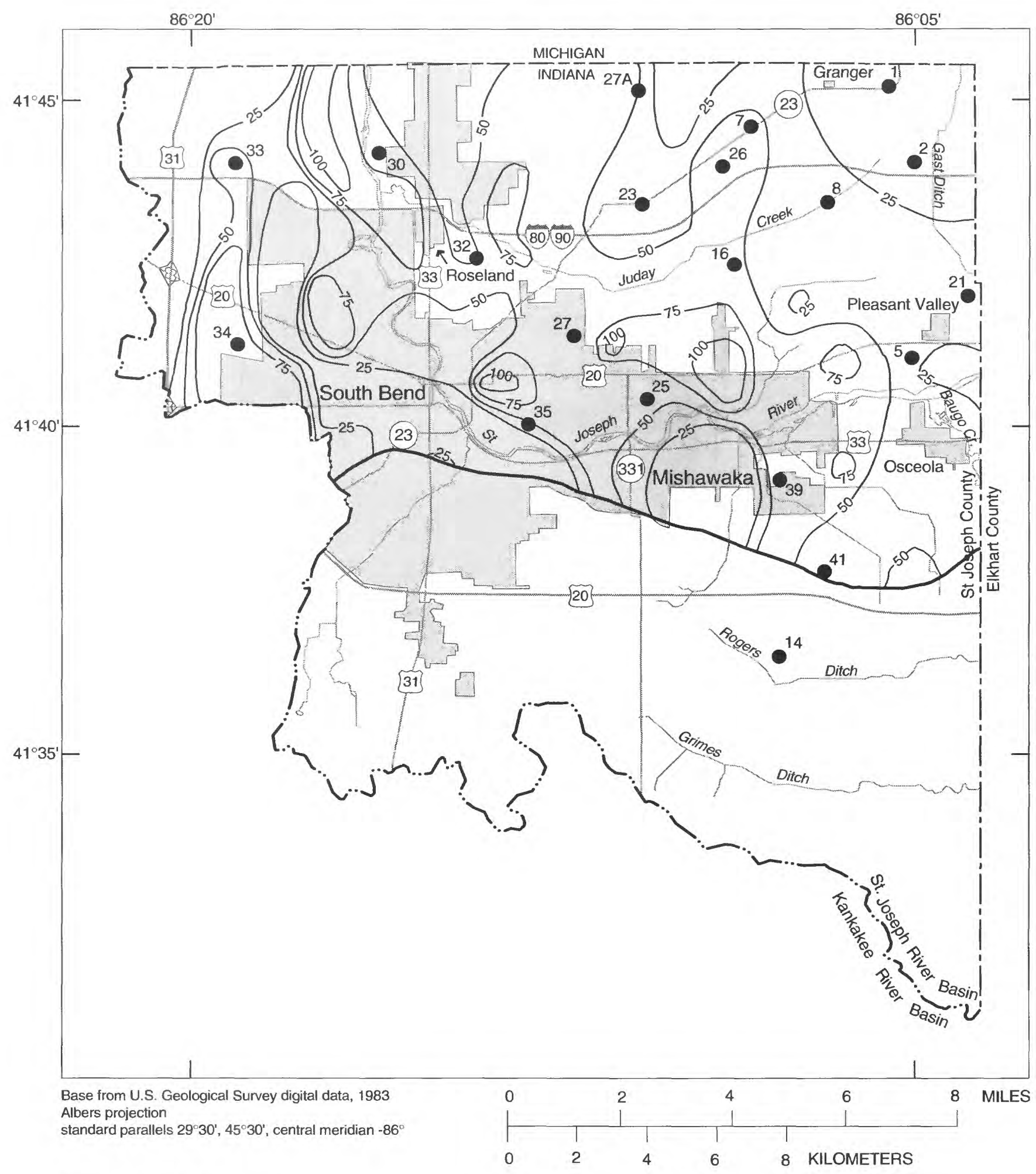

\section{EXPLANATION}

-25 LINE OF EQUAL THICKNESS OF CONFINING UNIT - Interval 25 feet

-..- St. Joseph River drainage divide

22 Well site and identifier

Figure 4. Thickness of confining unit separating the shallow aquifer from the deep aquifer in the St. Joseph aquifer system, northeastern St. Joseph County, Indiana. 
25 to $150 \mathrm{gal} / \mathrm{min}$ (Clendenon and Beaty, 1987). The Nappanee aquifer system is characterized by thin sand and gravel units (3-20 ft thick) contained within relatively thick sequences of till. Areal extent of the aquifers is limited to less than $2 \mathrm{mi}^{2}$ (Clendenon and Beaty, 1987). Pumping rates in the Nappanee aquifer system range from 50 to $600 \mathrm{gal} / \mathrm{min}$ (Clendenon and Beaty, 1987).

The Ellsworth Shale of DevonianMississippian age underlying the unconsolidated deposits in the study area (Schneider and Keller, 1970 ) is not used as a source of water. The lower part of the Ellsworth Shale generally consists of alternating grayish-green and brownish-black shale beds; the upper part consists of grayishgreen shale with lenses of dolomite or laminated dolomite (Shaver and others, 1986). The bedrock dips toward the Michigan Basin (north-northeast) at an angle of less than 1 degree.

\section{General Hydrology}

The St. Joseph River is the primary drainage in the study area. The river enters the study area at the county line east of South Bend, meanders westward and slightly southward to the middle of South Bend, and then turns northward and flows into Michigan. The stage and discharge of the St. Joseph River are controlled by dams built for power generation. The major tributaries of the St. Joseph River in the study area are Juday Creek (also known as Judy Creek) and Baugo Creek. Baugo Creek flows into the St. Joseph River near the far eastern edge of the study area; its tributaries drain the southeastern part of the study area. Smaller streams and ditches also contribute to the surface drainage. Small lakes are numerous just outside of the drainage basin on the western and northern sides of the study area.

About 38 in. of precipitation fall on the study area each year. Approximately 10.6 in/yr of the precipitation recharge the St. Joseph aquifer system (Clendenon and Beaty, 1987). The Hilltop and Nappanee aquifer systems receive less recharge per year (6.4 and 3.7 in., respectively) (Clendenon and Beaty, 1987) because of the low-permeability till that overlies the aquifers and the deep water table. Precipitation that does not recharge the ground-water system either becomes storm runoff or is evaporated or transpired into the atmosphere. Water from the aquifer systems is withdrawn by wells for public and domestic water supplies, industrial operations, irrigation, and livestock watering, and it discharges as base flow to the St. Joseph River and its tributaries.

Regional ground-water flow is towards the St. Joseph River (fig. 5), but local groundwater flow near the water table may be affected by creeks, ditches, local variations in geology, and pumpage. Depth to ground water ranges from less than $5 \mathrm{ft}$ in low-lying outwash deposits of the St. Joseph aquifer system to more than $80 \mathrm{ft}$ in topographically higher areas of the St. Joseph aquifer system and in the clay-rich deposits of the Nappanee and Hilltop aquifer systems.

The clay-rich unit in the St. Joseph aquifer system can be a barrier to vertical ground-water flow. In general, where the clay-rich unit has a relatively large clay content (a gamma-log reading of greater than 2,000 counts per second) and is more than $30 \mathrm{ft}$ thick, the difference in heads between the shallow and deep aquifers is large $(5-25 \mathrm{ft})$. Where the clay content and the thickness of the clay-rich unit are small, head differences between the shallow and deep aquifers are relatively small (less than $5 \mathrm{ft}$ ). Small head differences may indicate relatively unrestricted flow between the shallow aquifer and the deep aquifer.

Although the St. Joseph River flows through the northeastern part of St. Joseph County, ground water is the source of drinking water for most people in the study area. In 1989, a total of 14 municipal well fields were being used in the study area (Michiana Area Council of Governments, 1989), and pumping from at least 1 more well field has begun since then. Ground-waterwithdrawal capabilities reported in 1986 for 53 registered significant withdrawal sites (14 percent not reporting) were $122.31 \mathrm{Mgal} / \mathrm{d}$. Actual use at those 53 sites was $34.67 \mathrm{Mgal} / \mathrm{d}$ (Clendenon and 


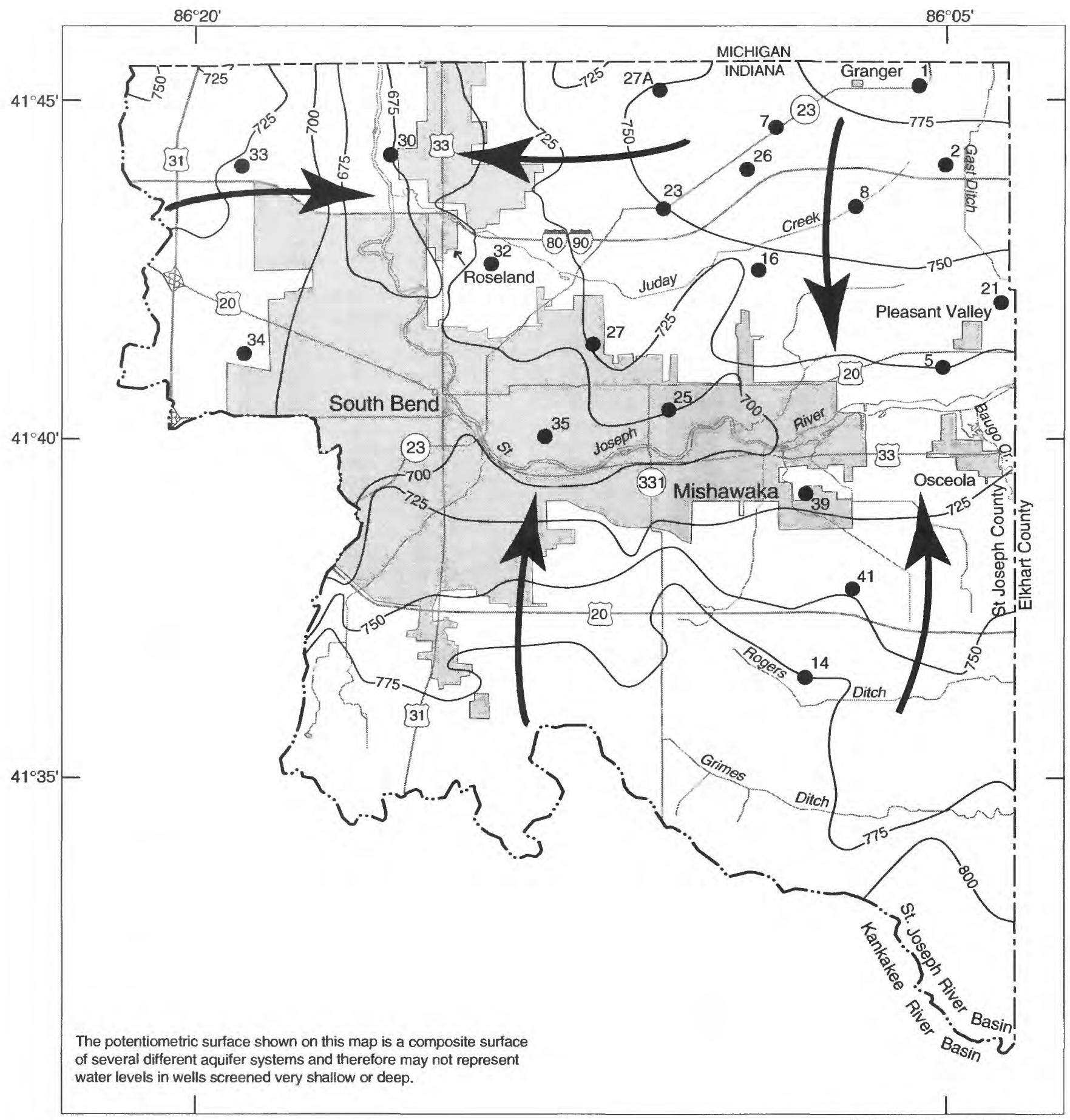

Base from U.S. Geological Survey digital data, 1983 Albers projection

standard parallels $29^{\circ} 30^{\prime}, 45^{\circ} 30^{\circ}$, central meridian $-86^{\circ}$

\section{EXPLANATION}

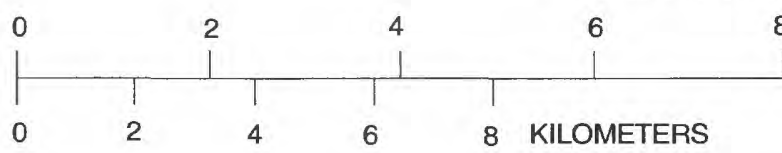

MILES

-725- POTENTIOMETRIC SURFACE CONTOUR- Shows altitude of potentiometric surface. Contour interval is 25 feet. Datum is sea level

$\longrightarrow$ St. Joseph River drainage divide
$\longrightarrow$ General direction of ground-water flow
22 Well site and identifier

Figure 5. General configuration and altitude of the potentiometric surface in the unconsolidated deposits, northeastern St. Joseph County, Indiana. 
Beaty, 1987). Estimated withdrawals by nonregistered users in 1987, primarily by domestic wells of rural St. Joseph County, accounted for less than 9 percent of the total ground-water withdrawals.

In the St. Joseph aquifer system, residential wells are usually less than $50 \mathrm{ft}$ deep. Most of the public-supply well fields generally tap the St. Joseph aquifer system at depths greater than $100 \mathrm{ft}$. Residential wells may be greater than $150 \mathrm{ft}$ deep in areas of the Nappanee aquifer system. The Hilltop and Nappanee aquifer systems are little used for public-supply well fields because of the limited ground-water availability in these aquifer systems.

\section{METHODS}

Boreholes were drilled to obtain lithologic information of the unconsolidated deposits. Monitoring wells were constructed in 52 of the boreholes to measure water levels and to collect water-quality samples. Thirty of the 52 wells were sampled for this study (table 1). The monitoring wells were selected so that the water quality of the aquifers could be characterized generally (fig. 1). Wells were selected on the basis of (1) land use, (2) presence or absence of the clay-rich unit that separates the shallow aquifer and the deep aquifer, and (3) suspected flow paths in the aquifers. Wells were selected from among the three major landuse categories in the study area-agricultural, urban, and mixed - which are discussed in the section, "Data Analysis." Wells were intentionally screened in either the shallow or the deep aquifer to compare water quality with depth. Nested wells, which consist of two or three wells screened at different depths, were constructed at eight of the sites. Monitoring wells were assigned a two-part identifier: the first part refers to the site number (fig. 1); the second part refers to the depth of the well. For example, well $23-55$ is located at site 23 and is $55 \mathrm{ft}$ deep.

\section{Monitoring-Well Construction}

Monitoring wells were installed in two phases during 1990-91 by use of different drilling methods. A hollow-stem auger was used to install 18 wells, ranging in depth from 22 to $130 \mathrm{ft}$. A mud-rotary drill was used to install 12 wells, ranging in depth from 85 to $173 \mathrm{ft}$; only bentonite was used in the drilling mud. A mud-rotary drill was used during the second phase to drill in sand and gravel to greater depths than was possible with the hollow-stem auger. To the degree possible, well specifications were the same for all wells. All wells were constructed by use of flush-joint, 2-in. inside-diameter polyvinyl chloride (PVC) casing and slotted screens. Each screen is $5 \mathrm{ft}$ in length. Widths of the slot openings of screens for the wells drilled with the hollow-stem auger and mud-rotary drill are 0.010 and $0.020 \mathrm{in}$., respectively. All well components, including casing plugs, casings, screens and casing caps, were steam cleaned to remove any contaminants before the wells were installed in the borehole.

Artificial gravel pack was used in the wells that were installed in borings drilled by mud-rotary methods. Artificial gravel pack was not used in the wells that were drilled with the hollow-stem auger because aquifer sand and gravel filled in around the wells after the auger was removed from the borehole. Bentonite grout was used to seal the annular spaces between the well casings and the borehole walls. A polymer emulsion was added to the grout to retard the swelling of the bentonite granules and to allow more time to place the grout. The grout was emplaced in the annular spaces under pressure by use of a tremie pipe for both methods of drilling. All wells were grouted from approximately $5 \mathrm{ft}$ above the screen openings to $4 \mathrm{ft}$ below land surface; concrete filled the remaining $4 \mathrm{ft}$ of annular space. At the surface, a locking steel well protector was set into a 6-in.-thick concrete pad. 


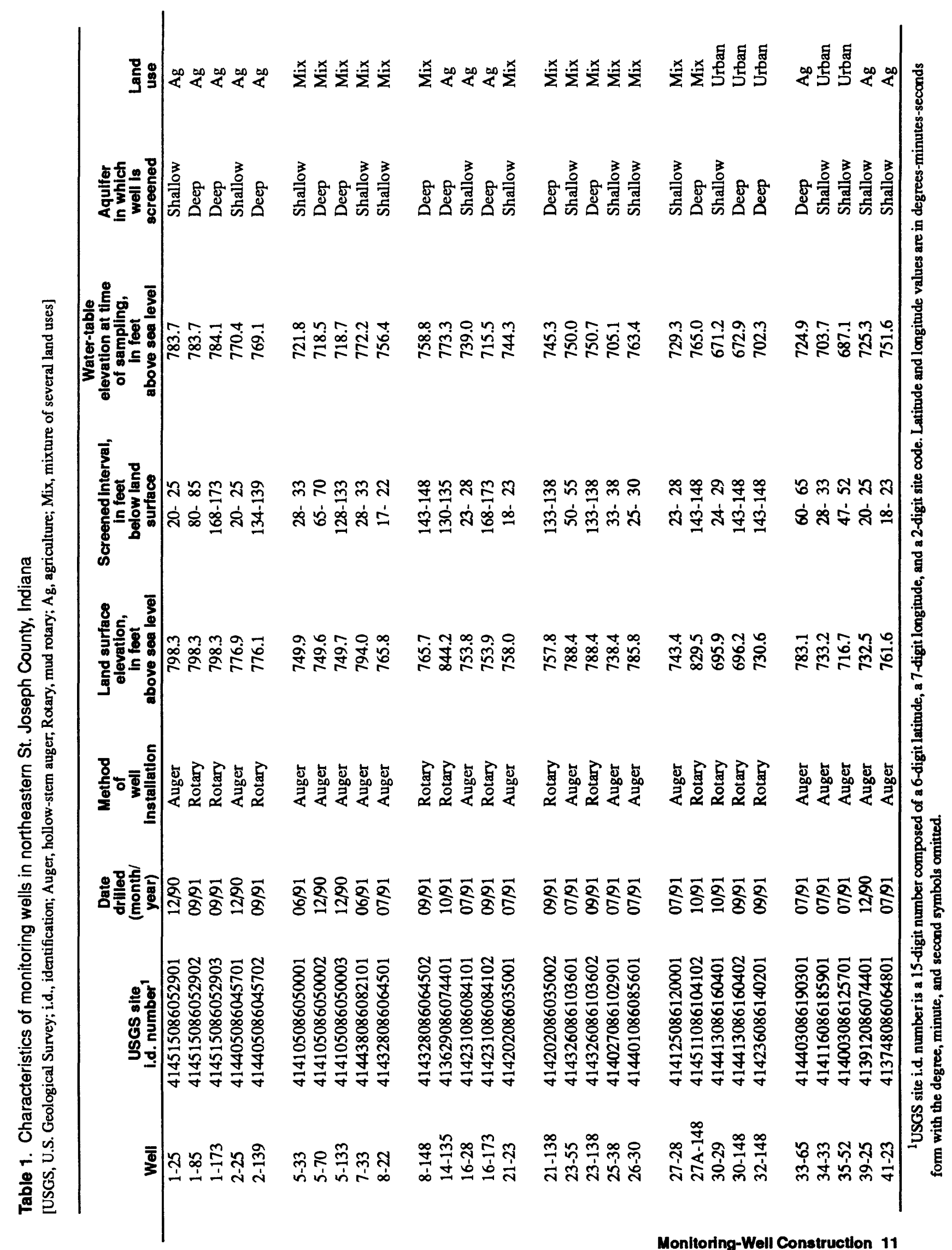


All wells were developed by use of either a gasoline-driven downhole pump or a suction pump. Wells were pumped at a rate that would not dewater the screened interval. Water from the wells was generally free of visible sediment and cloudiness after pumping 20 to 60 minutes. Yields of all wells were adequate for sampling.

\section{Water-Quality Sampling}

The water-quality samples were collected in order to characterize the general quality of ground water in the study area. Detection of industrial compounds or anomalously large concentrations of constituents that might result from human activities were not expected in this study because monitoring-well sites were selected to avoid known or suspected sites of groundwater contamination (see Michiana Area Council of Governments, 1989). Differences in concentrations related to depth and land use were expected in the study area because differences in groundwater quality related to aquifer depth and land use were found in a similar hydrogeologic and land-use setting in adjacent Elkhart County, Ind. (Imbrigiotta and Martin, 1981).

\section{Sample Collection}

Water samples were collected from 30 wells during May 18-May 27, 1992. Seven qualityassurance (QA) samples also were collected. The QA sample-collection methods are discussed in the section, "Quality Assurance."

Before samples were collected from each well, the depth to water was measured with a steel tape. At least three casing volumes were removed by use of a rotor-stator submersible pump attached to polytetrafluoroethylene hoses. The bottom of the pump was set at the top of the well screen. The pumping rate was approximately $1 \mathrm{gal} / \mathrm{min}$.

After a minimum of three casing volumes was removed, the discharge tube was connected to a stainless-steel flow-through cell. Water characteristics measured in the field- $\mathrm{pH}$, specific conductance, temperature, and dissolved-oxygen concentration-were monitored with a multiprobe water-quality meter; values were recorded when they stabilized. The multiprobe meter was calibrated for $\mathrm{pH}$, specific conductance, and dissolved-oxygen concentration at each site before measurements were made. Additional standards of specific conductance and $\mathrm{pH}$ were used to check the calibration.

After the field measurements of water-quality characteristics were completed, the flow-through cell was disconnected and samples were collected according to the order and the filtration, preservation, and container information listed in table 2. Field alkalinity was measured by incremental titration with sulfuric acid of an unfiltered 0.1-L sample. Samples for all inorganic analytes except nutrients (table 3 ) were passed under pressure through a 142-millimeter diameter, 0.45 -micrometer pore size, cellulose-acetate filter. Samples were acidified or preserved when appropriate, chilled, and sent to the USGS National Water Quality Laboratory (NWQL) in Denver, Colo., where the samples were analyzed for most of the water-quality properties and constituents listed in tables 3-5. The only constituents in tables 3-5 that were not analyzed by the NWQL are fieldmeasured properties and those pesticides in table 5 that are discussed in the following section, "Enzyme-Linked Immunosorbent Assay." Most of the organic compounds are U.S. Environmental Protection Agency (USEPA) priority pollutants. Analytical methods used by the NWQL are described in Wershaw and others (1987) and Fishman and Friedman (1989).

After water was collected and processed at each well, the submersible pump and hoses were flushed with approximately 5 gal of deionized water from a stainless-steel, free-standing reservoir. Filters were discarded after each use, and filter assemblies were rinsed with deionized water. 
Table 2. Collection, preparation, and preservation requirements for ground-water samples submitted for laboratory analysis

[mL, milliliter, C, Celsius; PTFE, Polytetrafluoroethylene]

\begin{tabular}{|c|}
\hline Analytes (in order of sample collection) \\
\hline $\begin{array}{l}\text { Nitrite plus nitrate, as nitrogen; nitrite, as nitrogen; ammonia, } \\
\text { as nitrogen; ammonia plus organic nitrogen, as nitrogen; } \\
\text { phosphorus; and orthophosphate, as phosphorus }\end{array}$ \\
\hline Methylene-blue-active substances \\
\hline Solids, residue at $105-110^{\circ} \mathrm{C}$ \\
\hline $\begin{array}{l}\text { Base/neutral plus acid extractable semivolatile organic } \\
\text { compounds }\end{array}$ \\
\hline $\begin{array}{l}\text { Organochlorine compounds and organophosphorus insecticides } \\
\text { with gross polychlorinated biphenyls (PCB's) and gross } \\
\text { polychlorinated naphthalenes (PCN's) }\end{array}$ \\
\hline
\end{tabular}

Volatile organic compounds

Enzyme-linked immunosorbent assay analyses of triazine compounds, metolachlor, alachlor, carbofuran, and 2,4-D

Antimony, selenium, chloride, sulfate, and fluoride

Potassium, aluminum, arsenic, barium, beryllium, cadmium, calcium, cobalt, chromium, copper, iron, lead, lithium, magnesium, nickel, manganese, molybdenum, silica, sodium, silver, strontium, vanadium, and zinc

Dissolved organic carbon

One 125-mL clear glass bottle, pressure filtered through a 0.45 -micrometer silver filter with nitrogen gas, maintained at $4^{\circ} \mathrm{C}$

Mercury

One 500-mL clear, acid-rinsed glass bottle, filtered and preserved with one $10-\mathrm{mL}$ ampule of nitric acid/potassium dichromate $\left(\mathrm{HNO}_{3} / \mathrm{K}_{2} \mathrm{Cr}_{2} \mathrm{O}_{7}\right)$

Cyanide

One 250-mL white, polyethylene acid-rinsed bottle, filtered and preserved with sodium hydroxide $(\mathrm{NaOH})$ to $\mathrm{pH}>12.0$ 
Table 3. Inorganic constituents and properties determined in ground water in northeastern St. Joseph County, Indiana, and corresponding parameter codes, reporting limits, and U.S. Environmental Protection Agency Drinking Water Regulations and Health Advisories

[USGS, U.S. Geological Survey; USEPA, U.S. Environmental Protection Agency; --, no regulation; n.a., not applicable; ${ }^{\circ} \mathrm{C}$, temperature in degree Celsius; AL, Action Level; HA-1, Health Advisory for a noncarcinogenic chemical; MCL, Maximum Contaminant Level; SMCL, Secondary Maximum Contaminant Level; PMCL, Proposed Maximum Contaminant Level; mg/L, milligram per liter, $\mu \mathrm{g} / \mathrm{L}$, microgram per liter]

\begin{tabular}{|c|c|c|c|c|c|c|c|}
\hline \multirow{2}{*}{$\begin{array}{l}\text { Constituent or property } \\
\text { General water-quality properties } \\
\text { and constituents: }\end{array}$} & \multirow[t]{2}{*}{$\begin{array}{l}\text { WATSTORE } \\
\text { (USGS) } \\
\text { and } \\
\text { STORET } \\
\text { (USEPA) } \\
\text { parameter } \\
\text { code }\end{array}$} & \multicolumn{2}{|c|}{$\begin{array}{c}\text { Reporting } \\
\text { limit }\end{array}$} & \multicolumn{2}{|c|}{$\begin{array}{c}\text { USEPA } \\
\text { Drinking Water } \\
\text { Regulation or } \\
\text { Health Advisory }\end{array}$} & \multirow[t]{2}{*}{$\begin{array}{c}\text { Type of } \\
\text { USEPA } \\
\text { Drinking } \\
\text { Water } \\
\text { Regulation } \\
\text { or Health } \\
\text { Advisory }\end{array}$} & \multirow[t]{2}{*}{$\begin{array}{c}\text { Number } \\
\text { of samples } \\
\text { exceeding } \\
\text { Regulation } \\
\text { or } \\
\text { Advisory' }\end{array}$} \\
\hline & & & & & & & \\
\hline Specific conductance & 00095 & \multicolumn{2}{|c|}{ n.a. } & \multicolumn{2}{|c|}{-- } & - & -- \\
\hline $\mathrm{pH}$ & 00400 & \multicolumn{2}{|c|}{ n.a. } & \multicolumn{2}{|c|}{$6.5-8.5$ units } & SMCL & 0 \\
\hline Temperature & 00010 & \multicolumn{2}{|c|}{ n.a. } & \multicolumn{2}{|c|}{--} & -- & -- \\
\hline Oxygen, dissolved & 00300 & .1 & $\mathrm{mg} / \mathrm{L}$ & \multicolumn{2}{|c|}{--} & -- & -- \\
\hline Alkalinity, total & 00419 & 1 & $\mathrm{mg} / \mathrm{L}$ & \multicolumn{2}{|c|}{--} & -- & -- \\
\hline $\begin{array}{l}\text { Solids, dissolved, } \\
\text { residue at } 105^{\circ} \mathrm{C}\end{array}$ & 00500 & 1 & $\mathrm{mg} / \mathrm{L}$ & 500 & $\mathrm{mg} / \mathrm{L}$ & SMCL & 3 \\
\hline Hardness & 00900 & \multicolumn{2}{|c|}{ n.a. } & \multicolumn{2}{|l|}{--} & -- & -- \\
\hline Carbon, organic, dissolved & 00681 & .1 & $\mathrm{mg} / \mathrm{L}$ & \multicolumn{2}{|c|}{--} & -- & -- \\
\hline $\begin{array}{l}\text { Methylene-blue-active } \\
\text { substances, total }\end{array}$ & 38260 & .01 & $\mathrm{mg} / \mathrm{L}$ & .5 & $\mathrm{mg} / \mathrm{L}$ & SMCL & 0 \\
\hline \multicolumn{8}{|l|}{ Major ions and silica, dissolved: } \\
\hline Calcium & 00915 & .02 & $\mathrm{mg} / \mathrm{L}$ & \multicolumn{2}{|l|}{--} & -- & -- \\
\hline Magnesium & 00925 & .01 & $\mathrm{mg} / \mathrm{L}$ & \multicolumn{2}{|c|}{--} & -- & -- \\
\hline Sodium & 00930 & .2 & $\mathrm{mg} \cdot \mathrm{L}$ & \multicolumn{2}{|c|}{--} & -- & -- \\
\hline Potassium & 00935 & .01 & $\mathrm{mg} / \mathrm{L}$ & \multicolumn{2}{|c|}{--} & - & - \\
\hline Chloride & 00940 & .1 & $\mathrm{mg} / \mathrm{L}$ & 250 & $\mathrm{mg} / \mathrm{L}$ & SMCL & 0 \\
\hline Sulfate & 00945 & 1 & $\mathrm{mg} / \mathrm{L}$ & 250 & $\mathrm{mg} / \mathrm{L}$ & SMCL & 0 \\
\hline Fluoride & 00950 & .1 & $\mathrm{mg} / \mathrm{L}$ & $\begin{array}{l}4 \\
2\end{array}$ & \multirow[t]{2}{*}{$\begin{array}{l}\mathrm{mg} / \mathrm{L} \\
\mathrm{mg} / \mathrm{L}\end{array}$} & $\begin{array}{l}\text { MCL } \\
\text { SMCL }\end{array}$ & $\begin{array}{l}0 \\
0\end{array}$ \\
\hline Silica & 00955 & .01 & $\mathrm{mg} / \mathrm{L}$ & -- & & -- & -- \\
\hline \multicolumn{8}{|l|}{ Nutrients, total: } \\
\hline Ammonia, as $\mathrm{N}$ & 00610 & \multicolumn{2}{|c|}{$.002 \mathrm{mg} / \mathrm{L}$} & 30 & $\mathrm{mg} / \mathrm{L}$ & ${ }^{2} \mathrm{HA}-1$ & 0 \\
\hline $\begin{array}{l}\text { Ammonia plus organic nitrogen, } \\
\text { as } N\end{array}$ & 00625 & .2 & $\mathrm{mg} / \mathrm{L}$ & -- & & -- & -- \\
\hline Nitrite, as $\mathrm{N}$ & 00615 & .001 & $\mathrm{mg} / \mathrm{L}$ & 1 & $\mathrm{mg} / \mathrm{L}$ & MCL & 0 \\
\hline Nitrate plus nitrite, as $\mathbf{N}$ & 00630 & .005 & $\mathrm{mg} / \mathrm{L}$ & 10 & $\mathrm{mg} / \mathrm{L}$ & MCL & 2 \\
\hline Phosphorus & 00665 & .001 & $\mathrm{mg} / \mathrm{L}$ & -- & & -- & - \\
\hline Orthophosphate, as P & 70507 & .01 & $\mathrm{mg} / \mathrm{L}$ & -- & & - & - \\
\hline
\end{tabular}


Table 3. Inorganic constituents and properties determined in ground water in northeastern St. Joseph County, Indiana, and corresponding parameter codes, reporting limits, and U.S. Environmental Protection Agency Drinking Water Regulations and Health Advisories-Continued

\begin{tabular}{|c|c|c|c|c|c|c|}
\hline Constituent or property & $\begin{array}{c}\text { WATSTORE } \\
\text { (USGS) } \\
\text { and } \\
\text { STORET } \\
\text { (USEPA) } \\
\text { parameter } \\
\text { code }\end{array}$ & & $\begin{array}{l}\text { leporting } \\
\text { limit }\end{array}$ & $\begin{array}{c}\text { USEPA } \\
\text { Drinking Water } \\
\text { Regulation or } \\
\text { Health Advisory }\end{array}$ & $\begin{array}{c}\text { Type of } \\
\text { USEPA } \\
\text { Drinking } \\
\text { Water } \\
\text { Regulation } \\
\text { or Health } \\
\text { Advisory }\end{array}$ & $\begin{array}{c}\text { Number } \\
\text { of samples } \\
\text { exceeding } \\
\text { Regulation } \\
\text { or } \\
\text { Advisory }\end{array}$ \\
\hline \multicolumn{7}{|c|}{ Trace elements and cyanide, dissolved: } \\
\hline Aluminum & 01106 & 10 & $\mu \mathrm{g} / \mathrm{L}$ & $50-200 \mu \mathrm{g} / \mathrm{L}$ & SMCL & 0 \\
\hline Antimony & 01095 & 1 & $\mu \mathrm{g} / \mathrm{L}$ & $3 \mu \mathrm{g} / \mathrm{L}$ & HA-l & 1 \\
\hline Arsenic & 01000 & 1 & $\mu \mathrm{g} / \mathrm{L}$ & $50 \mu \mathrm{g} / \mathrm{L}$ & MCL & 0 \\
\hline Barium & 01005 & 2 & $\mu \mathrm{g} / \mathrm{L}$ & $2,000 \mu \mathrm{g} / \mathrm{L}$ & MCL & 0 \\
\hline Beryllium & 01010 & 5 & $\mu \mathrm{g} / \mathrm{L}$ & $1 \mu \mathrm{g} / \mathrm{L}$ & PMCL & 0 \\
\hline Cadmium & 01025 & 1 & $\mu \mathrm{g} / \mathrm{L}$ & $5 \mu \mathrm{g} / \mathrm{L}$ & MCL & 0 \\
\hline Chromium & 01030 & 5 & $\mu \mathrm{g} / \mathrm{L}$ & $100 \mu \mathrm{g} / \mathrm{L}$ & MCL & 0 \\
\hline Cobalt & 01035 & 3 & $\mu \mathrm{g} / \mathrm{L}$ & -- & -- & -- \\
\hline Copper & 01040 & 10 & $\mu \mathrm{g} / \mathrm{L}$ & $\begin{array}{l}1,300 \mu \mathrm{g} / \mathrm{L} \\
1,000 \mu \mathrm{g} / \mathrm{L}\end{array}$ & 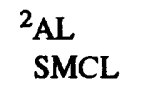 & $\begin{array}{l}0 \\
0\end{array}$ \\
\hline Cyanide & 00723 & 10 & $\mu \mathrm{g} / \mathrm{L}$ & $200 \mu \mathrm{g} / \mathrm{L}$ & HA-l & 0 \\
\hline Iron & 01046 & 3 & $\mu \mathrm{g} / \mathrm{L}$ & $300 \mu \mathrm{g} / \mathrm{L}$ & SMCL & 11 \\
\hline Lead & 01049 & 10 & $\mu \mathrm{g} / \mathrm{L}$ & $15 \mu \mathrm{g} / \mathrm{L}$ & $\mathrm{AL}$ & 0 \\
\hline Lithium & 01130 & 4 & $\mu \mathrm{g} / \mathrm{L}$ & -- & -- & -- \\
\hline Manganese & 01056 & 1 & $\mu \mathrm{g} / \mathrm{L}$ & $50 \mu \mathrm{g} / \mathrm{L}$ & SMCL & 15 \\
\hline Mercury & 71890 & & $1 \mu \mathrm{g} / \mathrm{L}$ & $2 \mu \mathrm{g} / \mathrm{L}$ & MCL & 0 \\
\hline Molybdenum & 01060 & 10 & $\mu \mathrm{g} / \mathrm{L}$ & $35 \mu \mathrm{g} / \mathrm{L}$ & ${ }^{2} \mathrm{HA}-\mathrm{l}$ & 0 \\
\hline Nickel & 01065 & 10 & $\mu \mathrm{g} / \mathrm{L}$ & $100 \mu \mathrm{g} / \mathrm{L}$ & HA-1 & 0 \\
\hline Selenium & 01145 & 1 & $\mu \mathrm{g} / \mathrm{L}$ & $50 \mu \mathrm{g} / \mathrm{L}$ & MCL & 0 \\
\hline Silver & 01075 & 1 & $\mu \mathrm{g} / \mathrm{L}$ & $\begin{array}{l}100 \mu \mathrm{g} / \mathrm{L} \\
100 \mu \mathrm{g} / \mathrm{L}\end{array}$ & $\begin{array}{l}{ }^{2} \mathrm{HA}-\mathrm{l} \\
\text { SMCL }\end{array}$ & $\begin{array}{l}0 \\
0\end{array}$ \\
\hline Strontium & 01080 & & $5 \mu \mathrm{g} / \mathrm{L}$ & $17,000 \mu \mathrm{g} / \mathrm{L}$ & ${ }^{2} \mathrm{HA}-\mathrm{l}$ & 0 \\
\hline Vanadium & 01085 & 6 & $\mu \mathrm{g} / \mathrm{L}$ & $20 \mu \mathrm{g} / \mathrm{L}$ & HA-1 & 0 \\
\hline Zinc & 01090 & 3 & $\mu \mathrm{g} / \mathrm{L}$ & $\begin{array}{l}2,100 \mu \mathrm{g} / \mathrm{L} \\
5,000 \mu \mathrm{g} / \mathrm{L}\end{array}$ & SMCL & $\begin{array}{l}0 \\
0\end{array}$ \\
\hline
\end{tabular}

${ }^{1}$ Drinking Water Regulations and Health Advisories from U.S. Environmental Protection Agency (1992).

${ }^{2}$ Draft status. 
Table 4. Base/neutral- and acid-extractable semivolatile organic compounds, polychlorinated biphenyls, and polychlorinated naphthalenes determined in ground water in northeastern St. Joseph County, Indiana, and corresponding parameter codes, reporting limits, and U.S. Environmental Protection Agency Drinking Water Regulations and Health Advisories

[USGS, U.S. Geological Survey; USEPA, U.S. Environmental Protection Agency; --, no regulation; $\mu \mathrm{g} / \mathrm{L}$, microgram per liter, HA-c, Health Advisory for a carcinogenic chemical; HA-1, Health Advisory for a noncarcinogenic chemical; MCL, Maximum Contaminant Level; PMCL, Proposed Maximum Contaminant Level; names in brackets indicate altemative nomenclature]

\begin{tabular}{|c|c|c|c|c|}
\hline Compound & $\begin{array}{l}\text { WATSTORE (USGS) } \\
\text { and } \\
\text { STORET (USEPA) } \\
\text { parameter code }\end{array}$ & $\begin{array}{c}\text { Reporting } \\
\text { limlt } \\
(\mu g / L)\end{array}$ & $\begin{array}{c}\text { USEPA } \\
\text { Drinking Water } \\
\text { Regulatlon or } \\
\text { Health Advisory } \\
(\mu \mathrm{g} / \mathrm{L})\end{array}$ & $\begin{array}{c}\text { Type of USEPA } \\
\text { Drinking Water } \\
\text { Regulation or } \\
\text { Health Advisory }\end{array}$ \\
\hline Acenaphthene & 34205 & 5 & $\overline{--}$ & -- \\
\hline Acenapthylene & 34200 & 5 & -- & -- \\
\hline Anthracene & 34220 & 5 & -- & -- \\
\hline Benzidine & 39120 & 20 & -- & - \\
\hline Benzo(a)pyrene & 34247 & 10 & .2 & PMCL \\
\hline Benzo(b)fluoranthene & 34230 & 10 & .2 & PMCL \\
\hline Benzo(k)fluoranthene & 34242 & 10 & .2 & PMCL \\
\hline $\begin{array}{l}\text { 1,2-Benzanthracene } \\
\text { [Benz(a)anthracene] }\end{array}$ & 34526 & 10 & .1 & PMCL \\
\hline $\begin{array}{l}\text { 1,12-Benzoperylene } \\
\text { [Benzo(g,h,i)perylene] }\end{array}$ & 34521 & 10 & -- & -- \\
\hline Bis (2-chloroethoxy) methane & 34278 & 5 & -- & -- \\
\hline Bis (2-chloroethyl) ether & 34273 & 5 & - & -- \\
\hline Bis (2-chloroisopropyl) ether & 34283 & 5 & 300 & HA-1 \\
\hline $\begin{array}{l}\text { Bis(2-ethylhexyl) phthalate } \\
\text { [Diethylhexyl phthalate] }\end{array}$ & 39100 & 5 & 4 & PMCL \\
\hline 4-Bromophenylphenyl ether & 34636 & 5 & -- & -- \\
\hline di-n-Butyl benzyl phthalate & 34292 & 5 & 100 & PMCL \\
\hline n-Butyl phthalate & 39110 & 5 & -- & -- \\
\hline 4-Chloro-3-methylphenol & 34452 & 30 & - & - \\
\hline 2-Chloronaphthalene & 34581 & 5 & -- & -- \\
\hline 2-Chlorophenol & 34586 & 5 & 40 & ${ }^{2} \mathrm{HA}-1$ \\
\hline 4-Chlorophenylphenyl ether & 34641 & 5 & -- & -- \\
\hline Chrysene & 34320 & 10 & -- & -- \\
\hline $\begin{array}{l}\text { 1,2-5,6-Dibenzanthracene } \\
\text { [Dibenz(a,h)anthracene] }\end{array}$ & 34556 & 10 & .3 & PMCL \\
\hline 1,2-Dichlorobenzene & 34536 & 5 & 600 & MCL \\
\hline 1,3-Dichlorobenzene & 34566 & 5 & 600 & MCL \\
\hline 1,4-Dichlorobenzene & 34571 & 5 & 75 & MCL \\
\hline 3,3'-Dichlorobenzidine & 34631 & 20 & -- & -- \\
\hline 2,4-Dichlorophenol & 34601 & 5 & 20 & ${ }^{2} \mathrm{HA}-1$ \\
\hline Diethyl phthalate & 34336 & 5 & 5,000 & ${ }^{2} \mathrm{HA}-1$ \\
\hline Dimethyl phthalate & 34341 & 5 & -- & -- \\
\hline
\end{tabular}


Table 4. Base/neutral- and acid-extractable semivolatile organic compounds, polychlorinated biphenyls, and polychlorinated naphthalenes determined in ground water in northeastern St. Joseph County, Indiana, and corresponding parameter codes, reporting limits, and U.S. Environmental Protection Agency Drinking Water Regulations and Health Advisories-Continued

\begin{tabular}{|c|c|c|c|c|}
\hline Compound & $\begin{array}{l}\text { WATSTORE (USGS) } \\
\text { and } \\
\text { STORET (USEPA) } \\
\text { parameter code }\end{array}$ & $\begin{array}{c}\text { Reporting } \\
\text { limit } \\
(\mu g / L)\end{array}$ & $\begin{array}{c}\text { USEPA } \\
\text { Drinking Water } \\
\text { Regulation or } \\
\text { Health Advisory' } \\
(\mu g / L)\end{array}$ & $\begin{array}{l}\text { Type of USEPA } \\
\text { Drinking Water } \\
\text { Regulation or } \\
\text { Health Advisory }\end{array}$ \\
\hline 2,4-Dimethylphenol & 34606 & 5 & -- & - \\
\hline Di-n-octyl phthalate & 34596 & 10 & -- & -- \\
\hline $\begin{array}{l}\text { Dinitrocresol } \\
\text { [4,6-Dinitro-ortho-cresol] }\end{array}$ & 34657 & 30 & -- & - \\
\hline 2,4-Dinitrophenol & 34616 & 20 & -- & -- \\
\hline 2,4-Dinitrotoluene & 34611 & 5 & 5,000 & HA-c \\
\hline 2,6-Dinitrotoluene & 34626 & 5 & 5,000 & HA-c \\
\hline 1,2-Diphenylhydrazine & 82626 & 5 & - & -- \\
\hline Fluoranthene & 34376 & 5 & -- & -- \\
\hline Fluorene & 34381 & 5 & -- & -- \\
\hline Hexachlorobenzene & 39700 & 5 & 2 & HA-c \\
\hline Hexachlorobutadiene & 39702 & 5 & 1 & HA-l \\
\hline Hexachlorocyclopentadiene & 34386 & 5 & 50 & PMCL \\
\hline Hexachloroethane & 34396 & 5 & 1 & HA-l \\
\hline Indeno(1,2,3-cd) pyrene & 34403 & 10 & .4 & PMCL \\
\hline Isophorone & 34408 & 5 & 100 & ${ }^{2} \mathrm{HA}-\mathrm{l}$ \\
\hline Napthalene & 34696 & 5 & 20 & HA-1 \\
\hline Nitrobenzene & 34447 & 5 & - & -- \\
\hline o-Nitrophenol [2-Nitrophenol] & 34591 & 5 & -- & -- \\
\hline p-Nitrophenol [4-Nitrophenol] & 34646 & 30 & 60 & ${ }^{2} \mathrm{HA}-\mathrm{l}$ \\
\hline n-Nitrosodimethylamine & 34438 & 5 & - & -- \\
\hline n-Nitrosodiphenylamine & 34433 & 5 & -- & -- \\
\hline n-Nitrosodi-n-propylamine & 34428 & 5 & -- & -- \\
\hline Pentachlorophenol & 39032 & 30 & 1 & MCL \\
\hline Phenanthrene & 34461 & 5 & -- & -- \\
\hline Phenol & 34694 & 5 & -- & -- \\
\hline PCB’s [Polychlorinated biphenyls] & 39517 & .1 & .5 & MCL \\
\hline PCN's [Polychlorinated naphthalenes] & 82360 & .1 & -- & -- \\
\hline Pyrene & 34469 & 5 & -- & -- \\
\hline 1,2,4-Trichlorobenzene & 34551 & 5 & 70 & HA-1 \\
\hline 2,4,6-Trichlorophenol & 34621 & 20 & 300 & ${ }^{2} \mathrm{HA}-\mathrm{c}$ \\
\hline
\end{tabular}

${ }^{1}$ Drinking Water Regulations and Health Advisories from U.S. Environmental Protection Agency (1992).

${ }^{2}$ Draft status. 
Table 5. Pesticides determined in ground water in northeastern St. Joseph County, Indiana, and corresponding parameter codes, reporting limits, and U.S. Environmental Protection Agency Drinking Water Regulations and Health Advisories

[USGS, U.S. Geological Survey; USEPA, U.S. Environmental Protection Agency; $\mu \mathrm{g} / \mathrm{L}$, microgram per liter, --, no regulation; HA-c, Health Advisory for a carcinogenic chemical; HA-1, Health Advisory for a noncarcinogenic chemical; MCL, Maximum Contaminant Level; names in brackets indicate altemative nomenclature]

\begin{tabular}{|c|c|c|c|c|}
\hline Compound & $\begin{array}{l}\text { WATSTORE (USGS) } \\
\text { and } \\
\text { STORET (USEPA) } \\
\text { parameter code }\end{array}$ & $\begin{array}{l}\text { Reporting limit } \\
(\mu g / L)\end{array}$ & $\begin{array}{c}\text { USEPA } \\
\text { Drinking Water } \\
\text { Regulation or Health } \\
\text { Advisory } 1 \\
\left(\mu g^{\prime} L\right)\end{array}$ & $\begin{array}{l}\text { Type of USEPA } \\
\text { Drinking Water } \\
\text { Regulation or } \\
\text { Health Advlsory' }\end{array}$ \\
\hline Alachlor & 82695 & 0.1 & 2 & MCL \\
\hline Aldrin & 39331 & .01 & .2 & ${ }^{2} \mathrm{HA}-\mathrm{c}$ \\
\hline Carbofuran & 82692 & .1 & 40 & MCL \\
\hline Carbophenothion [Trithion] & 82342 & .01 & -- & -- \\
\hline Chlordan(e) & 39352 & .1 & 2 & MCL \\
\hline 2,4-D & 82697 & 1 & 70 & MCL \\
\hline DDD & 39361 & .01 & -- & -- \\
\hline DDE & 39366 & .01 & -- & -- \\
\hline DDT & 39371 & .01 & -- & -. \\
\hline Diazinon & 39572 & .01 & .6 & HA-l \\
\hline Dieldrin & 39381 & .01 & .2 & ${ }^{2} \mathrm{HA}-\mathrm{c}$ \\
\hline Endosulfan & 82354 & .01 & -- & -- \\
\hline Endrin & 39391 & .01 & 2 & HA-1 \\
\hline Ethion & 82346 & .01 & -- & -- \\
\hline Heptachlor & 39411 & .01 & .4 & MCL \\
\hline Heptachlor epoxide & 39421 & .01 & .2 & MCL \\
\hline Lindane & 39341 & .01 & .2 & MCL \\
\hline Malathion & 39532 & .01 & 200 & ${ }^{2} \mathrm{HA}-1$ \\
\hline Methoxychlor & 82350 & .01 & 40 & $\mathrm{MCL}$ \\
\hline Methyl parathion & 39602 & .01 & 2 & HA-1 \\
\hline Methyl trithion & 82344 & .01 & -- & -- \\
\hline Metolachlor & 82694 & .1 & 100 & HA-1 \\
\hline Mirex & 39756 & .01 & -. & -- \\
\hline Parathion & 39542 & .01 & -- & -- \\
\hline Perthane & 82348 & .1 & -- & -- \\
\hline Toxaphene & 39401 & 1.0 & 3 & MCL \\
\hline Triazine compounds: & 34756 & & & \\
\hline Atrazine & & .1 & 3 & MCL \\
\hline Ametryn & & .1 & 60 & HA-1 \\
\hline Propazine & & .1 & 10 & HA-1 \\
\hline Prometryn & & .1 & -- & -. \\
\hline Simazine & & .34 & 4 & HA-1 \\
\hline Terbutryn & & .1 & -- & -- \\
\hline Terbutylazine & & .31 & -. & -- \\
\hline De-ethylated atrazine & & .1 & -- & -- \\
\hline Cyanazine & & 1.0 & 1 & HA-1 \\
\hline 6-Hydroxy atrazine & & 1.1 & -- & -- \\
\hline
\end{tabular}

${ }^{1}$ Drinking Water Regulations and Health Advisories from U.S. Environmental Protection Agency (1992).

${ }^{2}$ Draft status.

18 Ground-Water Quality in Northeastern St. Joseph County, indiana 
A portable gas chromatograph (PGC) was used in the field to screen for the presence of volatile organic compounds in water samples from the $\mathbf{3 0}$ monitoring wells. Five ground-water samples were collected for analysis by gas chromatography/mass spectroscopy (GC/MS) at the NWQL to quantify possible detections measured with the PGC. This aspect of the sampling activities is described further in the section, "Portable Gas Chromatography."

Concentrations of the triazine compounds (one family of agricultural chemicals) and four specific compounds-alachlor, metolachlor, 2,4-D, and carbofuran-were analyzed in the USGS office in Indianapolis, Ind., by use of enzyme-linked immunosorbent assay methods. This method is described further in the section, "Enzyme-Linked Immunosorbent Assay."

\section{Portable Gas Chromatography}

A portable gas chromatograph (PGC) equipped with a photoionization detector having a lamp energy of 10.6 electron volts $(\mathrm{eV})$ was used in the field to screen water samples from the 30 wells and several QA samples for the presence of volatile organic compounds. The PGC was used for field screening of volatile organic compounds because it is less expensive than GC/MS, especially when nondetectable concentrations of volatile organic compounds are expected.

PGC analyses for volatile organic compounds were done by trained staff from the NWQL. The PGC was calibrated before each field setup; no more than four samples were analyzed between calibrations. The calibration standard contained the compounds trans1,2-dichloroethylene, cis-1,2-dichloroethylene, benzene, trichloroethylene, toluene, tetrachloroethylene, and $\mathrm{m}$-xylene. Equipment and syringe blanks were analyzed after calibration to ensure proper baseline readings. Samples for volatile organic compounds analysis were collected and preserved according to the methods listed in table 2 for volatile organic compounds. Immediately before analysis, $20 \mathrm{~mL}$ of water were removed from the chilled $40-\mathrm{mL}$ vial, and the remaining liquid was shaken vigorously to induce volatile organic compounds to partition into the headspace gas. A sample of the headspace gas was removed with a syringe and injected into the PGC.

Five ground-water samples (from wells 5-33, 5-70, 5-133, 23-55, and 27A-148) had suspect peaks of unknown volatile organic compounds, as indicated by the PGC field chromatographs, and were forwarded to the NWQL for GC/MS analysis of the volatile organic compounds listed in table 6. A GC/MS analysis was done to identify and quantify these suspected detections of volatile organic compounds.

The PGC is a semiquantitative instrument and is best used as a screening tool. The PGC is able to detect volatile organic compounds with ionization potentials less than $10.6 \mathrm{eV}$; a few compounds such as carbon tetrachloride, chloroform, methylene chloride, and the chloroethanes can be detected even though their ionization potentials are greater than $10.6 \mathrm{eV}$ (Brock, 1990, p. 2). Volatile organic compounds with ionization potentials greater than $10.6 \mathrm{eV}$ may be detected if they occur in high concentrations (greater than $1 \mathrm{mg} / \mathrm{L}$ ) (Duane Wydoski, U.S. Geological Survey, oral commun., 1993). Many volatile organic compounds that are commonly used in industrial applications can be detected with the PGC. These include benzene, toluene, xylene, dichloroethylenes, trichloroethylene, tetrachloroethylene, vinyl chloride, chlorobenzene, and ethylbenzene (Brock, 1990, table 1). In general, the PGC will detect only aromatic hydrocarbons and alkenes (Brock, 1990, p. 3). 
Table 6. Volatile organic compounds determined in ground water in northeastern St. Joseph County, Indiana, and corresponding parameter codes, reporting limits, and U.S. Environmental Protection Agency Drinking Water Regulations and Health Advisories

[Table applies only to those water samples analyzed with gas chromatography/mass spectroscopy. USGS, U.S. Geological Survey; USEPA, U.S. Environmental Protection Agency; $\mu \mathrm{g} / \mathrm{L}$, microgram per liter; --, no regulation; HA-c, Health Advisory for a carcinogenic chemical; HA-1, Health Advisory for a noncarcinogenic chemical; MCL, Maximum Contaminant Level; names in brackets indicate alternative nomenclature]

\begin{tabular}{|c|c|c|c|c|}
\hline Compound & $\begin{array}{l}\text { WATSTORE } \\
\text { (USGS) and } \\
\text { STORET } \\
\text { (USEPA) } \\
\text { parameter code }\end{array}$ & $\underset{(\mu g / L)}{R}$ & $\begin{array}{l}\text { USEPA } \\
\text { Drinking Water } \\
\text { Regulatlon or } \\
\text { Health Advisory' } \\
(\mu g / L)\end{array}$ & $\begin{array}{c}\text { Type of USEPA } \\
\text { Drinking Water } \\
\text { Regulation or } \\
\text { Health } \\
\text { Advisory }\end{array}$ \\
\hline Acrolein & 34210 & 20 & -- & -- \\
\hline Acrylonitrile & 34215 & 20 & 7 & ${ }^{2} \mathrm{HA}-\mathrm{c}$ \\
\hline Benzene & 34030 & .2 & 5 & MCL \\
\hline Bromobenzene & 81555 & .2 & -- & -- \\
\hline Bromochloromethane & 77297 & .2 & 90 & HA-1 \\
\hline Bromoform & 32104 & .2 & 400 & ${ }^{2} \mathrm{HA-c}$ \\
\hline Bromodichloromethane & 32101 & .2 & 60 & ${ }^{2} \mathrm{HA}-\mathrm{c}$ \\
\hline n-Butylbenzene & 77342 & .2 & -- & -- \\
\hline sec-Butylbenzene & 77350 & .2 & -- & -- \\
\hline tert-Butylbenzene & 77353 & .2 & -- & -- \\
\hline Carbon tetrachloride & 32102 & .2 & 5 & MCL \\
\hline Chlorobenzene & 34301 & .2 & -- & -- \\
\hline Chlorodibromomethane & 32105 & .2 & 60 & HA-1 \\
\hline Chloroethane & 34311 & .2 & -- & -- \\
\hline 2-Chloroethlyvinylether & 34576 & 1 & -- & -- \\
\hline Chloroform & 32106 & .2 & 600 & ${ }^{2} \mathrm{HA}-\mathrm{c}$ \\
\hline 2-Chlorotoluene & 77275 & .2 & 100 & HA-l \\
\hline 4-Chlorotoluene & 77277 & .2 & 100 & HA-1 \\
\hline Dibromochloropropane [DBCP] & 82625 & 1 & .2 & MCL \\
\hline 1,2-Dibromoethane [EDB] & 77651 & .2 & .05 & MCL \\
\hline Dibromomethane & 30217 & .2 & -- & $-\cdot$ \\
\hline 1,2-Dichlorobenzene ${ }^{3}$ & 34536 & .2 & 600 & MCL \\
\hline 1,3-Dichlorobenzene ${ }^{3}$ & 34566 & .2 & 600 & MCL \\
\hline 1,4-Dichlorobenzene ${ }^{3}$ & 34571 & .2 & 75 & MCL \\
\hline Dichlorodifluoromethane & 34668 & .2 & 1,000 & HA-1 \\
\hline 1,1-Dichloroethane & 34496 & .2 & -- & -- \\
\hline 1,2-Dichloroethane & 32103 & .2 & 5 & MCL \\
\hline cis-1,2-Dichloroethylene & 77093 & .2 & 70 & MCL \\
\hline trans-1,2-Dichloroethylene & 34546 & .2 & 100 & MCL \\
\hline 1,1-Dichloroethylene & 34501 & .2 & 7 & MCL \\
\hline
\end{tabular}


Table 6. Volatile organic compounds determined in ground water in northeastern St. Joseph County, Indiana, and corresponding parameter codes, reporting limits, and U.S. Environmental Protection Agency Drinking Water Regulations and Health Advisories-Continued

\begin{tabular}{|c|c|c|c|c|}
\hline Compound & $\begin{array}{l}\text { WATSTORE } \\
\text { (USGS) and } \\
\text { STORET } \\
\text { (USEPA) } \\
\text { parameter code }\end{array}$ & $\underset{(\mu g / L)}{\text { Reporting limit }}$ & $\begin{array}{c}\text { USEPA } \\
\text { Drinking Water } \\
\text { Regulation or } \\
\text { Heaith Advisory' } \\
(\mu g / L)\end{array}$ & $\begin{array}{c}\text { Type of USEPA } \\
\text { Drinking Water } \\
\text { Regulation or } \\
\text { Health } \\
\text { Advlsory' }\end{array}$ \\
\hline 1,2-Dichloropropane & 34541 & .2 & 5 & $\overline{M C L}$ \\
\hline 1,3-Dichloropropane & 77173 & .2 & - & -- \\
\hline 2,2-Dichloropropane & 77170 & .2 & -- & -- \\
\hline 1,1-Dichloropropene & 77168 & .2 & -- & -- \\
\hline cis-1,3-Dichloropropene & 34704 & .2 & - & -- \\
\hline trans-1,3-Dichloropropene & 34699 & .2 & - & -- \\
\hline Ethylbenzene & 34371 & .2 & 700 & MCL \\
\hline Hexachlorobutadiene ${ }^{3}$ & 39702 & .2 & 1 & HA-1 \\
\hline Isopropyl benzene & 77223 & .2 & - & -- \\
\hline p-Isopropyl toluene [p-Cymene] & 77356 & .2 & - & -- \\
\hline Methyl bromide [Bromomethane] & 34413 & .2 & 10 & HA-l \\
\hline Methyl chloride [Chloromethane] & 34418 & .2 & 3 & HA-1 \\
\hline Methyl tert-butyl ether [MTBE] & 78032 & 1 & 40 & ${ }^{2} \mathrm{HA}-\mathrm{l}$ \\
\hline Methylene chloride [Dichloromethane] & 34423 & .2 & 500 & HA-c \\
\hline Napthalene $^{3}$ & 34696 & .2 & 20 & HA-1 \\
\hline n-Propylbenzene & 77224 & .2 & -- & -- \\
\hline Styrene & 77128 & .2 & 100 & MCL \\
\hline 1,1,1,2-Tetrachloroethane & 77562 & .2 & 100 & HA-c \\
\hline 1,1,2,2-Tetrachloroethane & 34516 & .2 & -- & -- \\
\hline Tetrachloroethylene & 34476 & .2 & 5 & MCL \\
\hline Toluene & 34010 & .2 & 1,000 & MCL \\
\hline 1,2,3-Trichlorobenzene & 77613 & .2 & -- & -- \\
\hline 1,2,4-Trichlorobenzene ${ }^{3}$ & 34551 & .2 & 70 & HA-1 \\
\hline 1,1,1-Trichloroethane & 34506 & .2 & 200 & MCL \\
\hline 1,1,2-Trichloroethane & 34511 & .2 & 3 & HA-1 \\
\hline Trichloroethylene & 39180 & .2 & 5 & MCL \\
\hline Trichlorofluoromethane & 34488 & .2 & 2,000 & HA-1 \\
\hline 1,2,3-Trichloropropane & 77443 & .2 & 40 & HA-1 \\
\hline Trichlorotrifluoroethane [Freon 113] & 77652 & .5 & - & -- \\
\hline 1,2,4-Trimethylbenzene [Pseudocumene] & 77222 & .2 & - & -- \\
\hline 1,3,5-Trimethylbenzene [Mesitylene] & 77226 & .2 & -- & -- \\
\hline Vinyl chloride & 39175 & .2 & 2 & MCL \\
\hline Xylenes [Dimethylbenzenes] & 81551 & .2 & 10,000 & MCL \\
\hline
\end{tabular}

${ }^{1}$ Drinking Water Regulations and Health Advisories from U.S. Environmental Protection Agency (1992).

${ }^{2}$ Draft status.

${ }^{3}$ These compounds were also analyzed as methylene-chloride extractable compounds. 


\section{Enzyme-Linked Immunosorbent Assay}

Concentrations of one family of agricultural chemicals (the triazines) and four specific compounds (alachlor, metolachlor, 2,4-D, and carbofuran) were measured in the USGS office in Indianapolis, Ind., by use of enzyme-linked immunosorbent assay (ELISA) methods. ELISA methods are inexpensive and quick but are only semiquantitative. Goolsby and others (1991) have shown that results from ELISA compare well to results from GC/MS for measuring pesticide concentrations in water.

Descriptions of the methods used in sample collection and preservation are listed in table 2 . Samples were chilled at $4^{\circ} \mathrm{C}$ until 3 hours before analysis, at which time they were allowed to warm to room temperature. The analytical method entails the reaction of an enzyme-linked antibody that is coated on a magnetic particle with a specific pesticide that might be present in a $200-\mu \mathrm{L}$ sample of water. Coated particles were reacted with a color reagent, and the absorbance of each sample was measured with a digital spectrophotometer.

To calculate a pesticide concentration, one compares the measured light absorbance of a water sample to a regression equation relating measured light absorbances of water samples to standards of known pesticide concentrations. A regression equation was developed for each pesticide before analysis of the water samples. Standards used for triazines, alachlor, carbofuran, and metolachlor were $0.00 \mu \mathrm{g} / \mathrm{L}, 0.01 \mu \mathrm{g} / \mathrm{L}, 1 \mu \mathrm{g} / \mathrm{L}$, and $5 \mu \mathrm{g} / \mathrm{L}$. Standards for 2,4-D were $0.00 \mu \mathrm{g} / \mathrm{L}, 1 \mu \mathrm{g} / \mathrm{L}$, $10 \mu \mathrm{g} / \mathrm{L}$, and $50 \mu \mathrm{g} / \mathrm{L}$. Triplicate samples were prepared for each standard. A coefficient of variation was calculated from the absorbance values of each set of triplicate standards. An absorbance value that caused the coefficient of variation to exceed 10 percent was removed from the data set before a regression equation was fit to the data; no more than 1 of the 12 values was ever removed from the data set. Following calibration, a control solution was analyzed as an internal check of spectrophotometer calibration.

\section{Data Analysis}

Results of the water-quality measurements are discussed by comparing them (1) by depth (shallow aquifer compared to deep aquifer), (2) by agricultural, urban, and mixed land-use types, and (3) to USEPA Drinking Water Regulations and Health Advisories. Depth (shallow or deep) and landuse types for each well are listed in table 1. USEPA Drinking Water Regulations and Health Advisories are listed for many of the sampled constituents in tables 3-6. Results of the waterquality measurements from this study also are compared to selected inorganic analyses from an IDNR study of the St. Joseph River Basin (Clendenon and Beaty, 1987, Appendix 14). The analyses are from as many as 44 wells in the study area that are screened in the St. Joseph aquifer system (fig. 2) at depths of 70 to $329 \mathrm{ft}$ below land surface. The 44 deep-screened wells consist of municipal and industrial wells and several domestic wells.

Concentrations of constituents in the 16 shallow and 14 deep wells were statistically compared by use of the Wilcoxon-Mann-Whitney rank-sum test (Helsel and Hirsch, 1992, p. 118124). Sampled wells used for the test that are less than $60 \mathrm{ft}$ below land surface are screened in the shallow aquifer, those deeper than $60 \mathrm{ft}$ are screened in the deep aquifer. The rank-sum test was used to determine whether water-quality differences between samples from the shallow aquifer and samples from the deep aquifer were statistically significant. Differences in concentrations between water samples from the shallow and deep wells are discussed only if they are significant $(0.01<p<0.05)$ or highly significant $(p<0.01)$; $p$ is the probability that an observed difference is due to chance rather than depth. The lower the p-value, the more likely an observed difference is due to depth rather than chance. For example, a p-value of 0.01 has a 1 -percent probability ( 0.01 times 100 equals 1 percent) of being due to chance rather than depth, whereas a p-value of 0.20 has a 20 -percent probability ( 0.20 times 100 equals 20 percent) of being due to chance rather than depth. 
The sampled wells were grouped by primary land use-agricultural, urban, or a mixed area of agricultural and urban. Land-use identification accounted for the area immediately surrounding and about $1 \mathrm{mi}$ upgradient from a well site. South Bend, Mishawaka, and adjacent suburbs are the primary urban areas (fig. 1). Large parts of the study area consist of agricultural areas with pockets of low-density housing that are classified as mixed land-use areas in this report. Differences in concentrations between water samples from the three land-use types are qualitatively compared and discussed in this text only if a relation between water type and land use was noticed or expected.

The USEPA (1992) has established primary drinking-water regulations, termed Maximum Contaminant Levels (MCL's), which limit the concentration of certain constituents in public water systems. A MCL is finalized after consideration of acceptable risks of adverse human health effects, technological capabilities, and economic costs of achieving the health-protection goals.

The USEPA (1992) also issues Health Advisories for certain constituents in drinking water. A Health Advisory is a non-enforceable concentration associated with risks of toxicity or cancer due to different lengths of exposure to a chemical. Although USEPA typically starts with a Health Advisory to determine a Proposed MCL (PMCL), the Health Advisory is not adjusted by economic or technological factors, as is the final MCL. Many chemicals for which there is no MCL do have a Health Advisory in draft or final form. A Health Advisory for noncarcinogenic chemicals (HA-1) is set to protect human health for a lifetime of exposure. A Health Advisory for carcinogens (HA-c) is calculated for a 1 in 10,000 probability of lifetime cancer risk.

In this discussion, if a MCL does not exist, a HA-1 or HA-c is used for comparison to a constituent concentration. For noncarcinogens, the HA-1 used is the adult lifetime exposure concentration. For carcinogens, the HA-c corresponding to a cancer-risk probability of 1 in 10,000 was used instead of the HA-1. A PMCL is compared to an analyte concentration only if no final HA-1, HA-c, or MCL has been established for that analyte.
The USEPA (1992) also has established secondary drinking-water regulations, termed Secondary Maximum Contaminant Levels (SMCL's), which are recommended guidelines for drinking water. SMCL's apply to aesthetic qualities of water such as taste, potential for pipe corrosion, or staining of laundry. SMCL's are used, in addition to the regulations and advisories discussed above, for comparison to an analyte concentration.

\section{QUALITY ASSURANCE}

Quality-assurance samples-field replicates, field blanks, equipment blanks, and field spikeswere intended to identify potential systematic problems with the reported results. Systematic problems are attributed to inappropriate or poorly applied techniques including (1) decontamination of sampling equipment, (2) collection, preservation and transportation of samples and sampling equipment, and (3) analytical determinations of the chemical concentrations or magnitudes of physical properties.

\section{Field Replicates}

Field replicates are multiple samples collected in close succession at the same well site. The chemistry of the water from replicate samples is assumed to be nearly identical; therefore, comparison of replicate analyses is used to show variations in concentrations of analytes that may be attributed to sampling and laboratory methods. Three replicate samples were collected sequentially from well 34-33 and analyzed for all inorganic and organic constituents measured in this study. A standard deviation was calculated from the analyses of each inorganic constituent and general water-quality property (table 7). Except for dissolved solids, the constituents listed in table 7 had relatively low standard deviations; the greatest variability was found in constituents with concentrations that approach the reporting 


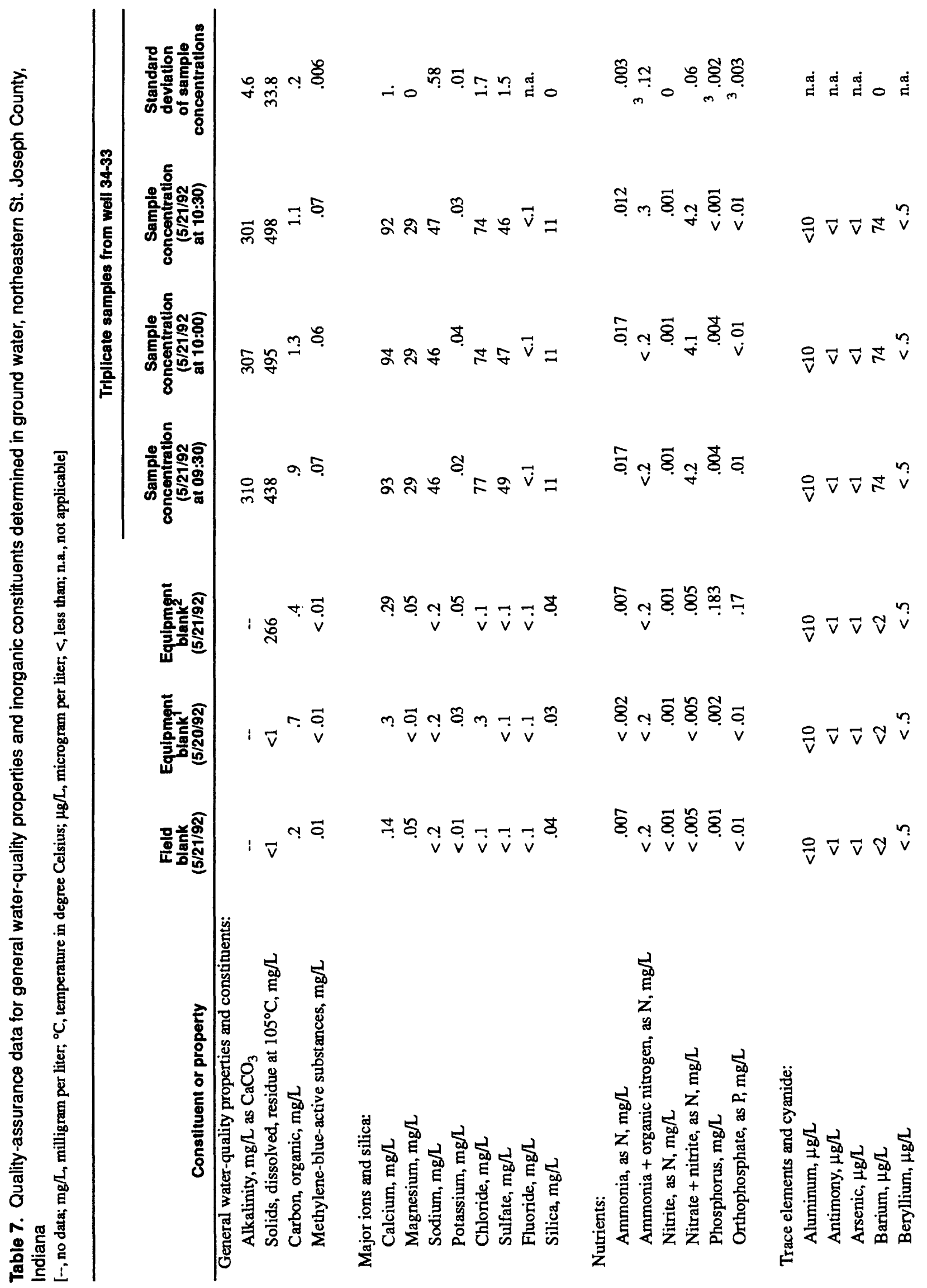




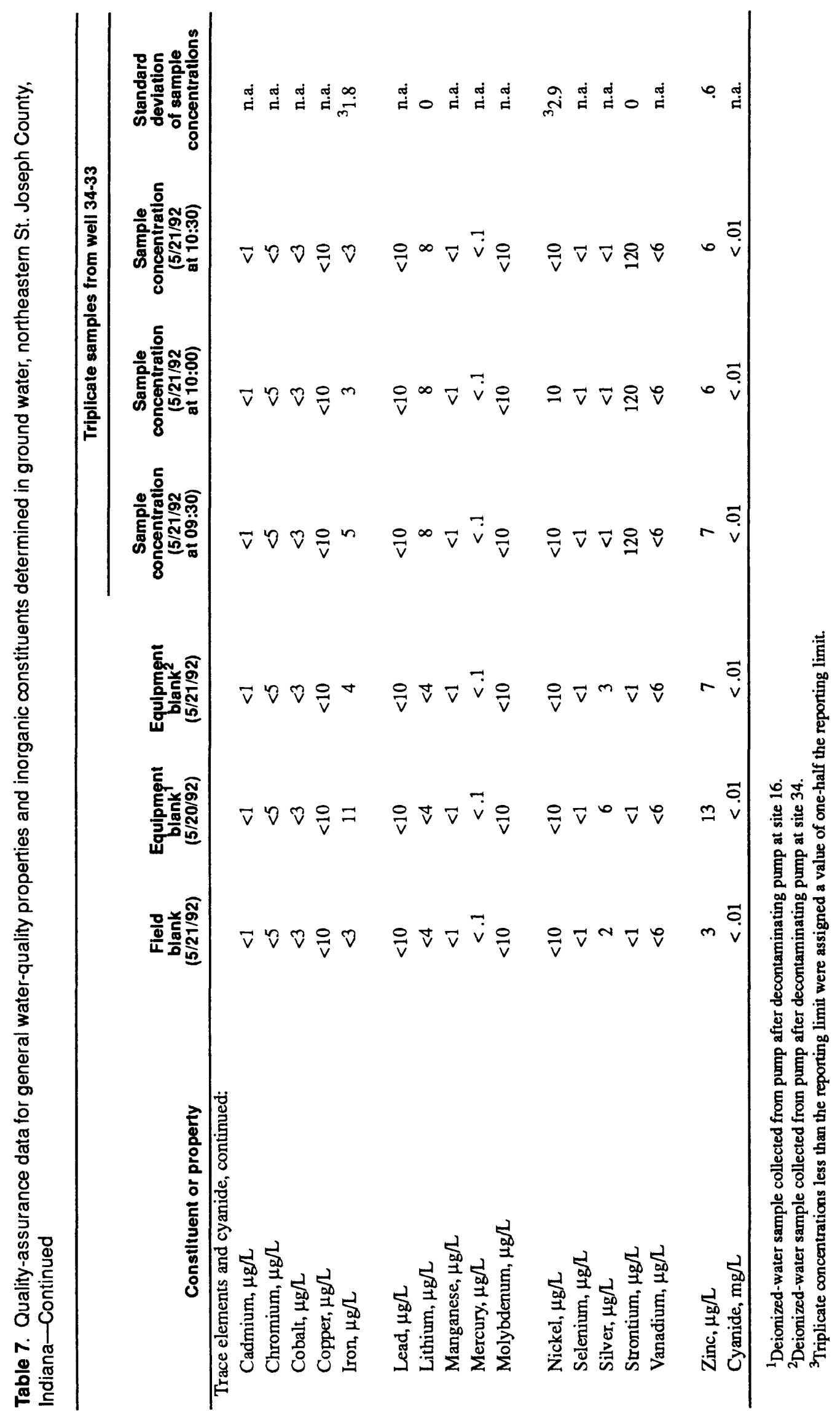


limit ${ }^{2}$. No organic chemicals were detected in any of the replicate samples; therefore, standard deviations for the concentrations of organic chemicals were not calculated.

\section{Blanks}

A field blank and two equipment blanks were collected during the sampling period and analyzed for the same analytes as all other water samples. The purpose of the field blank was to identify contamination of the sample from (1) impure deionized water, (2) contaminated sample containers, or (3) poor handling of samples in the field and(or) the laboratory. Equipment blanks were collected to ensure that post-collection cleaning procedures removed all detectable concentrations of compounds from the submersible pump, pumpto-surface tubing, and filter mechanism. The equipment blanks were deionized water collected from the end of the sampling tube connected to the submersible pump after the pump and tubing were rinsed with deionized water and a new filter was installed. The equipment blanks were collected at sites 16 and 34 . The field blank consisted of a sample of the deionized water collected from a plastic carboy that was in a field vehicle.

Fifteen inorganic constituents (dissolved solids and specific conductance are discussed later) were detected in field and equipment blanks (table 7); 12 were detected at concentrations exceeding the minimum value reported in the ground-water samples. Ammonia, phosphorus, silver, zinc, organic carbon, and methylene-blueactive substances were detected in the field blank and may be the result of contaminated deionized water. Potassium, chloride, ammonia, nitrite, nitrate plus nitrite, phosphorus, orthophosphate, iron, silver, and zinc were detected in the equipment blanks at concentrations greater than the field blanks; the presence of these constituents

\footnotetext{
${ }^{2}$ The reporting limit is the minimum concentration reported by the NWQL.
}

is probably the result of insufficient cleaning of the sampling equipment. Contaminants introduced from improper cleaning procedures or from the deionized water may have increased the concentrations of these 12 constituents in the ground-water samples (table 11, at back of report). The only organic chemicals detected in the water from the sampled wells were the pesticides carbofuran, triazines, alachlor, and metolachlor; carbofuran was not analyzed for in the blanks, whereas the latter three pesticides were not detected in the blanks.

The effect of contamination in the sampling equipment on the concentrations of inorganic constituents in the ground-water samples is unknown. Before ground-water samples were collected at a well and after decontamination of the equipment, a minimum of $5 \mathrm{gal}$ of sample water passed through the pump and tubing. This practice may have enabled some of the contaminants residing in the sampling equipment, such as those detected in the equipment blanks, to be flushed out before samples were collected. All bottles also were field rinsed with sample water before sample collection to remove any contaminant residue from the bottle.

Mercury was detected in two ground-water samples. However, mercury was not detected in field and equipment blanks; this provides evidence that the sampling procedure did not contribute mercury to the ground-water samples. Mercury also was not detected by the NWQL in blind mercury-free quality-assurance samples analyzed within 2 weeks of the ground-water samples.

Analysis of the field blank and one equipment blank by GC/MS for the volatile organic compounds listed in table 6 detected the presence of four compounds: 1,2-dichlorobenzene, 1,3-dichlorobenzene, 1,4-dichlorobenzene, and toluene. Subsequent testing of the waterpurification system in the USGS office in Indianapolis found it to be the source of three of the four compounds listed above as well as dichlorobenzene, methylene chloride, and styrene. 
Volatile organic compounds were not detected in ground-water samples, an indication that cleaning the equipment with deionized water before rinsing with sample water did not contaminate the groundwater samples.

Two ground-water samples and one equipment blank had dissolved-solids concentrations measured from the mass of residue upon evaporation of the water sample (TDS-res) that were more than double the dissolved-solids concentrations calculated as the sum of the mass of the constituents (TDS-calc). The two TDS-res concentrations from the ground-water samples were removed from the data set and attributed (together with the equipment blank TDS-res concentration) to possible bottle mixups in the laboratory. Because of the problems with the TDS-res concentrations in the triplicates, equipment blank, and water sample data set, the TDS-calc concentrations are considered a better data set than the TDS-res concentrations and were used in all calculations and comparisons for this report.

\section{Spikes}

A field spike is a ground-water or QA sample that has a known concentration of one or more compounds added to it. Field spikes are designed to monitor the amount of solute that can be lost to biological degradation, inadequate sample preservation and transportation, errors in analytical procedure, or matrix effects. Matrix effects are interferences in the recovery of analytes from the sample that are caused by the matrix (samplewater chemistry). In this study, one water sample collected at well 32-148 and one organic-free water sample were spiked with a mixture of 29 volatile organic compounds. The spiked samples were analyzed by the NWQL. Spike recoveries for all 29 compounds in both samples were within acceptable ranges. Both field spikes had equal or better percent recoveries for all but six of the compounds than the mean percent recovery of volatile organic compounds from all samples submitted for analysis to the NWQL in 1992 (Bruce Darnel, U.S. Geological Survey, written commun., 1993).
The NWQL has a well-defined program of quality assurance and quality control (QA/QC) that is described in Pritt and Raese (1992). As part of that program, the NWQL identified low recovery of organophosphate pesticide surrogates from water samples from wells 1-25, 1-173, 2-25, $21-23,21-138,25-38,30-148,32-148,34-33$ at 10:00 a.m., 34-33 at 10:30 a.m., 35-52, and 41-23. A surrogate is a compound that is chemically similar to the analyte of interest and is introduced into the ground-water sample upon arrival at the laboratory. The purpose of a surrogate spike is to determine the effect of the ground-water chemistry or matrix on the measured concentration or to identify other errors occurring during sample preparation or analysis. Organophosphate pesticides analyzed for this study included the compounds diazinon, ethion, malathion, methyl parathion, methyl trithion, parathion, and carbophenothion (trithion).

\section{Additional Quality-Assurance Steps}

Specific QA steps were taken to assure the quality of analyses by PGC and ELISA. Instrument blanks, syringe blanks, and samples of the deionized water used for rinsing sampling equipment were periodically analyzed on the PGC to ensure that an outside source of contamination or mechanical failure was not interfering with analyses of ground-water samples. As mentioned previously, samples with possible detections of volatile organic compounds also were analyzed at the NWQL. ELISA QA activities included postcalibration measurement of a standardized control solution to corroborate an acceptable calibration of the spectrophotometer. Concentrations of alachlor, carbofuran, 2,4-D, and metolachlor in the standardized control solutions were within 10 percent of the measured concentrations, whereas the atrazine control solution concentration of $3.00 \mu \mathrm{g} / \mathrm{L}$ had a measured concentration of $3.68 \mu \mathrm{g} / \mathrm{L}$. Replicate analyses of water samples from well 34-33 also were analyzed with ELISA. 
Water-quality data were entered into the USGS national data base, WATSTORE. Analytical data were checked for accuracy; anomalous data were reanalyzed or checked for accuracy against the NWQL data-entry and data-transfer record. Cation-anion balances were calculated for 28 water samples with complete ion analyses. In 19 of the water samples, the difference (in milliequivalents per liter) between cations and anions was less than 3 percent of the sum of the total cations and anions in the sample; in the remaining nine water samples, the difference was 4 to 8 percent.

\section{GROUND-WATER QUALITY}

Three Superfund National Priority List sites are located in the study area, and 101 abandoned waste-disposal sites in St. Joseph County have been listed (Indiana Department of Environmental Management, 1989, p. 252-53); the majority of the abandoned waste-disposal sites are within the study area. As a result of these sites and other industrial problems, 20 contaminated groundwater sites have been documented in the study area (Michiana Area Council of Governments, 1989). Wells that were sampled for this study were intentionally not located near these documented problem areas. The sampled wells were selected to characterize the general water quality, particularly in areas that may be future sites for public-supply well fields or areas that are undergoing rapid residential expansion.

\section{General Water-Quality Properties}

Data for five onsite measurements (specific conductance, $\mathrm{pH}$, temperature, oxygen, and alkalinity), dissolved solids, hardness, organic carbon, and methylene-blue-active substances are listed in table 11 in the "Supplemental Data" section at the back of this report. A statistical summary of these water-quality properties is given in table 8 .

The $\mathrm{pH}$ of the water ranged from 7.2 to 8.1. The water was near neutral to basic with respect . to $\mathrm{pH}$. No water samples were outside the SMCL range for $\mathrm{pH}$ of 6.5 to 8.5 .
Dissolved-solids concentration in the water samples had a median of $310 \mathrm{mg} / \mathrm{L}$ and a range of 202 to $763 \mathrm{mg} / \mathrm{L}$. Three water samples exceeded the SMCL for dissolved solids of $500 \mathrm{mg} / \mathrm{L}$ - two in the shallow aquifer and one in the deep aquifer. Concentrations of dissolved solids in water from 41 wells sampled by IDNR (Clendenon and Beaty, 1987) had a median of $463 \mathrm{mg} / \mathrm{L}$ and ranged from 240 to $713 \mathrm{mg} / \mathrm{L}$.

Water from all but one of the 30 wells sampled generally is considered "very hard"; that is, hardness is greater than $180 \mathrm{mg} / \mathrm{L}$ as equivalents of $\mathrm{CaCO}_{3}$ (Durfor and Becker, 1964, p. 27). The median hardness of water in this study $(275 \mathrm{mg} / \mathrm{L}$ as equivalents of $\mathrm{CaCO}_{3}$ ) is similar to the median hardness $\left(310 \mathrm{mg} / \mathrm{L}\right.$ as equivalents of $\left.\mathrm{CaCO}_{3}\right)$ of water from 43 wells compiled by Clendenon and Beaty (1987). Excessive hardness in water affects the ability of a soap to lather and can create scale in water heaters, boilers, and pipes.

Concentrations of dissolved oxygen were significantly greater in the water from the shallow aquifer than in the water from the deep aquifer (table 9). Median dissolved-oxygen concentration in the shallow aquifer was $4.6 \mathrm{mg} / \mathrm{L}$, whereas the median concentration in the deep aquifer was $0.4 \mathrm{mg} / \mathrm{L}$. Dissolved oxygen was detected at concentrations of $0.4 \mathrm{mg} / \mathrm{L}$ or greater in all but four of the water samples. Higher concentrations of dissolved oxygen in the shallow aquifer are not unexpected because the aquifer is primarily a surficial sand in which oxygenated recharge waters can infiltrate to the water table.

Concentrations of methylene-blue-active substances (MBAS) also were significantly higher in the shallow aquifer than in the deep aquifer. The median concentrations of MBAS in water samples from the shallow aquifer and the deep aquifer were 0.05 and $0.01 \mathrm{mg} / \mathrm{L}$, respectively. MBAS are surfactants, such as those used in detergents, and commonly are associated with wastewater and septic systems. Despite being associated with human activities, no relation was evident between land use and concentrations of MBAS in the water samples. The SMCL for foaming agents of $0.5 \mathrm{mg} / \mathrm{L}$ was not exceeded in the water samples. 


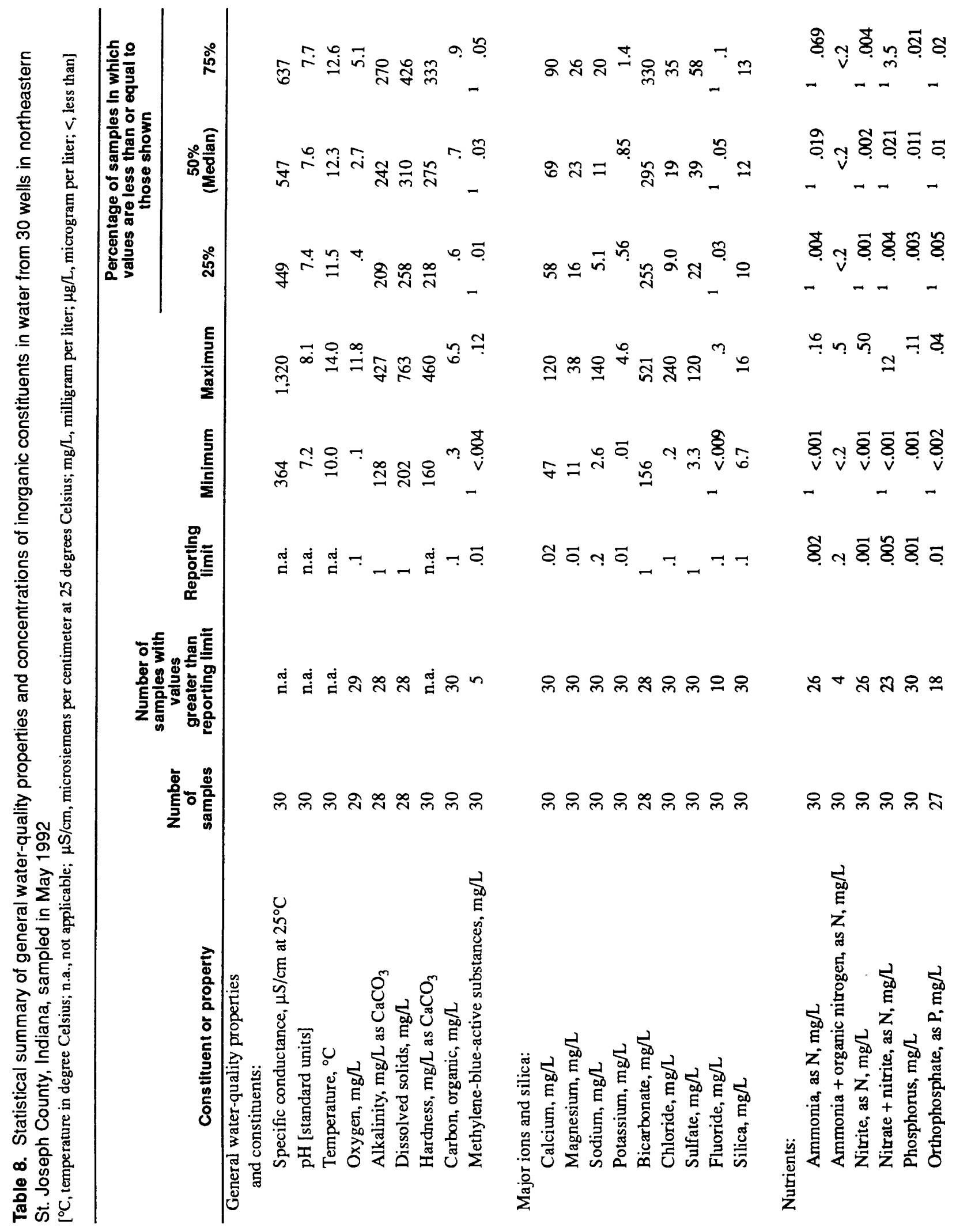




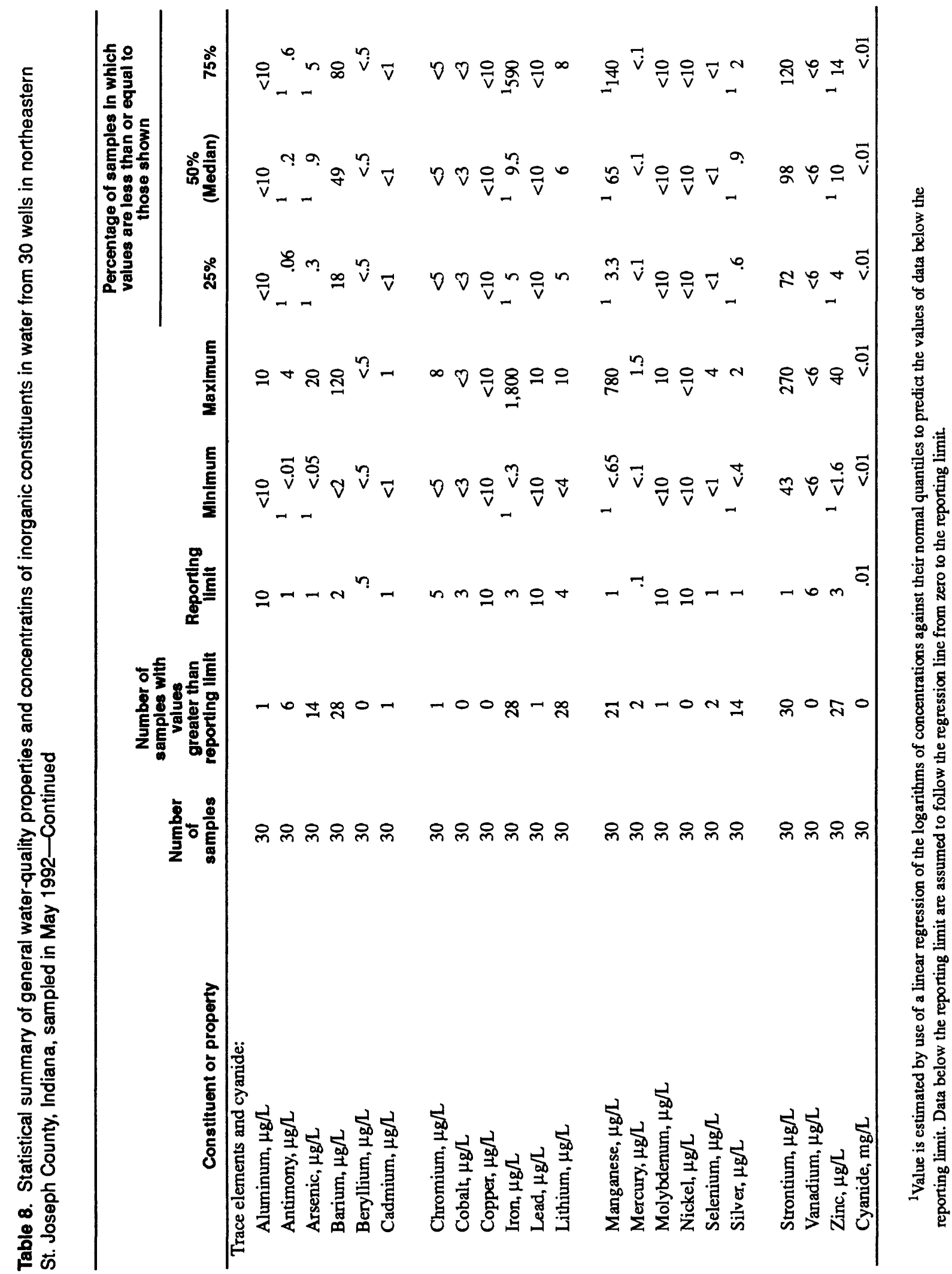


Table 9. Summary of results from Wilcoxon-Mann-Whitney rank sum test to determine differences in selected constituents between the shallow aquifer and the deep aquifer, northeastern St. Joseph County, Indiana

[p, the probability that an observed difference is due to chance rather than depth; ${ }^{*}$, significant difference $(0.01<p<0.05)$ between the shallow aquifer and the deep aquifer, ${ }^{* *}$, highly significant difference $(p<0.01)$ between the shallow aquifer and the deep aquifer, constituents or properties with p-values greater than 0.20 are not listed; $\mu \mathrm{S} / \mathrm{cm}$, microsiemens per centimeter, ${ }^{\circ} \mathrm{C}$, degree Celsius; mg/L, milligram per liter, $\mu \mathrm{g} / \mathrm{L}$, microgram per liter]

\begin{tabular}{|c|c|c|c|}
\hline Constituent or property & $\begin{array}{c}\text { Level } \\
\text { of } \\
\text { significance } \\
(p)\end{array}$ & $\begin{array}{c}\text { Median value } \\
\text { for } \\
\text { water } \\
\text { from } \\
\text { shallow aquifer }\end{array}$ & $\begin{array}{c}\text { Median value } \\
\text { for } \\
\text { water } \\
\text { from } \\
\text { doep aqulfer }\end{array}$ \\
\hline \multicolumn{4}{|l|}{ General water-quality properties and constituents: } \\
\hline Specific conductance, $\mu \mathrm{S} / \mathrm{cm}$ at $25^{\circ} \mathrm{C}$ & 0.11 & 610 & 490 \\
\hline pH [standard units] & .12 & 7.5 & 7.7 \\
\hline Temperature, ${ }^{\circ} \mathrm{C}$ & .20 & 11.8 & 12.5 \\
\hline Dissolved oxygen, $\mathrm{mg} / \mathrm{L}$ & $.002^{* *}$ & 4.6 & .4 \\
\hline Methylene-blue-active substances, $\mathrm{mg} / \mathrm{L}$ & $.00004 * *$ & .05 & .01 \\
\hline \multicolumn{4}{|l|}{ Major ions and silica: } \\
\hline Calcium, mg/L & .11 & 88 & 63 \\
\hline Sodium, mg/L & .10 & 16 & 8.4 \\
\hline Chloride, $\mathrm{mg} / \mathrm{L}$ & $.04 *$ & 32 & 13 \\
\hline Sulfate, $\mathrm{mg} / \mathrm{L}$ & .15 & 48 & 35 \\
\hline Fluoride, $\mathrm{mg} / \mathrm{L}$ & .20 & $<.1$ & $<.1$ \\
\hline Silica, mg/L & $.002 * *$ & 11 & 13 \\
\hline \multicolumn{4}{|l|}{ Nutrients } \\
\hline Ammonia, as $\mathrm{N}, \mathrm{mg} / \mathrm{L}$ & $.002^{* *}$ & .007 & .066 \\
\hline Nitrate plus nitrite, as $\mathrm{N}, \mathrm{mg} / \mathrm{L}$ & $.0004^{* *}$ & 2.5 & $<.005$ \\
\hline \multicolumn{4}{|l|}{ Trace elements: } \\
\hline Antimony, $\mu \mathrm{g} / \mathrm{L}$ & $.05^{*}$ & $<1$ & $<1$ \\
\hline Arsenic, $\mu \mathrm{g} / \mathrm{L}$ & $.001^{* *}$ & $<1$ & 5 \\
\hline Barium, $\mu \mathrm{g} / \mathrm{L}$ & $.01 *$ & 30 & 76 \\
\hline Iron, $\mu \mathrm{g} / \mathrm{L}$ & $.009 * *$ & 7 & 470 \\
\hline Manganese, $\mu \mathrm{g} / \mathrm{L}$ & $.008^{* *}$ & $<1$ & 130 \\
\hline
\end{tabular}




\section{Inorganic Constituents}

Data for the inorganic constituents in the 30 wells that were sampled for this study are listed in table 11 of the "Supplemental Data" section in the back of this report. These constituents consist of 4 major anions, silica, 4 major cations, 6 nutrients, 21 trace elements, and cyanide. A statistical summary of these constituents is presented in table 8 .

\section{Major Ions and Silica}

The major ions that were analyzed for this study include the cations calcium, magnesium, sodium, and potassium; and the anions bicarbonate, chloride, sulfate, and fluoride. Silica also is considered to be a major constituent and is discussed with the major ions. Drinking Water Regulations have been established for chloride, sulfate, and fluoride. No water sample for this study had a concentration that exceeded the limits set in these regulations (table 3).

The chemical composition of waters from the shallow aquifer and the deep aquifer have been plotted on a trilinear diagram (Piper, 1953) in figure 6. Cations and anions in each water sample are plotted as a percentage of the total cations and anions in the water sample, in milliequivalents per liter. The distribution of cations and anions in each water sample is shown in the left and right triangles, respectively. The cation and anion percentages on the triangular plots then are projected onto the central diamond-shaped field. The fields in the cation and the anion parts of a trilinear diagram have been subdivided. A single ion is considered dominant if it represents greater than 60 percent of the total cation or anion milliequivalents per liter. The interiors of the cation and anion parts of the diagram contain a central triangularshaped field of mixed water types where each of the three end members range from 20 to 60 percent. This triangular field is flanked by trapezoidal fields in which two of the end members are between 20 and 60 percent and the third is less than 20 percent. Examples of the two-ion fields are the calcium-magnesium and the bicarbonatesulfate fields.

The water in the two aquifers is predominantly a calcium bicarbonate or calcium magnesium-bicarbonate type (fig. 6). In general, the cations in ground water consist of about 50 to 70 percent calcium, 20 to 40 percent magnesium, and less than 25 percent sodium. In general, the anions in ground water consist of about 55 to 90 percent bicarbonate, less than 30 percent sulfate, and less than 25 percent chloride. There is little noticeable difference in the distribution of the major ions between the shallow aquifer and the deep aquifer. Concentrations of calcium, sodium, chloride, sulfate, and fluoride appear to be higher in the shallow aquifer, although only chloride has a significantly higher concentration in the shallow aquifer than in the deep aquifer (table 9). Median chloride concentrations in the shallow aquifer and the deep aquifer are 32 and $13 \mathrm{mg} / \mathrm{L}$, respectively. Silica is the only major constituent whose concentration is significantly higher in the deep aquifer (median, $13 \mathrm{mg} / \mathrm{L}$ ) than in the shallow aquifer (median, $11 \mathrm{mg} / \mathrm{L}$ ) (table 9).

An almost one-to-one relation between milliequivalents per liter of sodium and chloride indicates sodium chloride salt (halite) as a probable source of the elevated sodium and chloride concentrations in the shallow ground water (fig. 7). In the study area, road deicing salt and water-softener salt in septic systems are the primary sources of the sodium and chloride in the ground water resulting from human activity. Sodium chloride contamination is most evident in the shallow ground water near roads and houses. Seven of the highest 10 sodium plus chloride concentrations (in milliequivalents per liter) are from shallow wells in mixed or urban land-use groups (fig. 7). The water sample with the highest concentrations of sodium and chloride came from well 26-30. The well is adjacent to a road and near (but upgradient from) a salt-storage facility. 


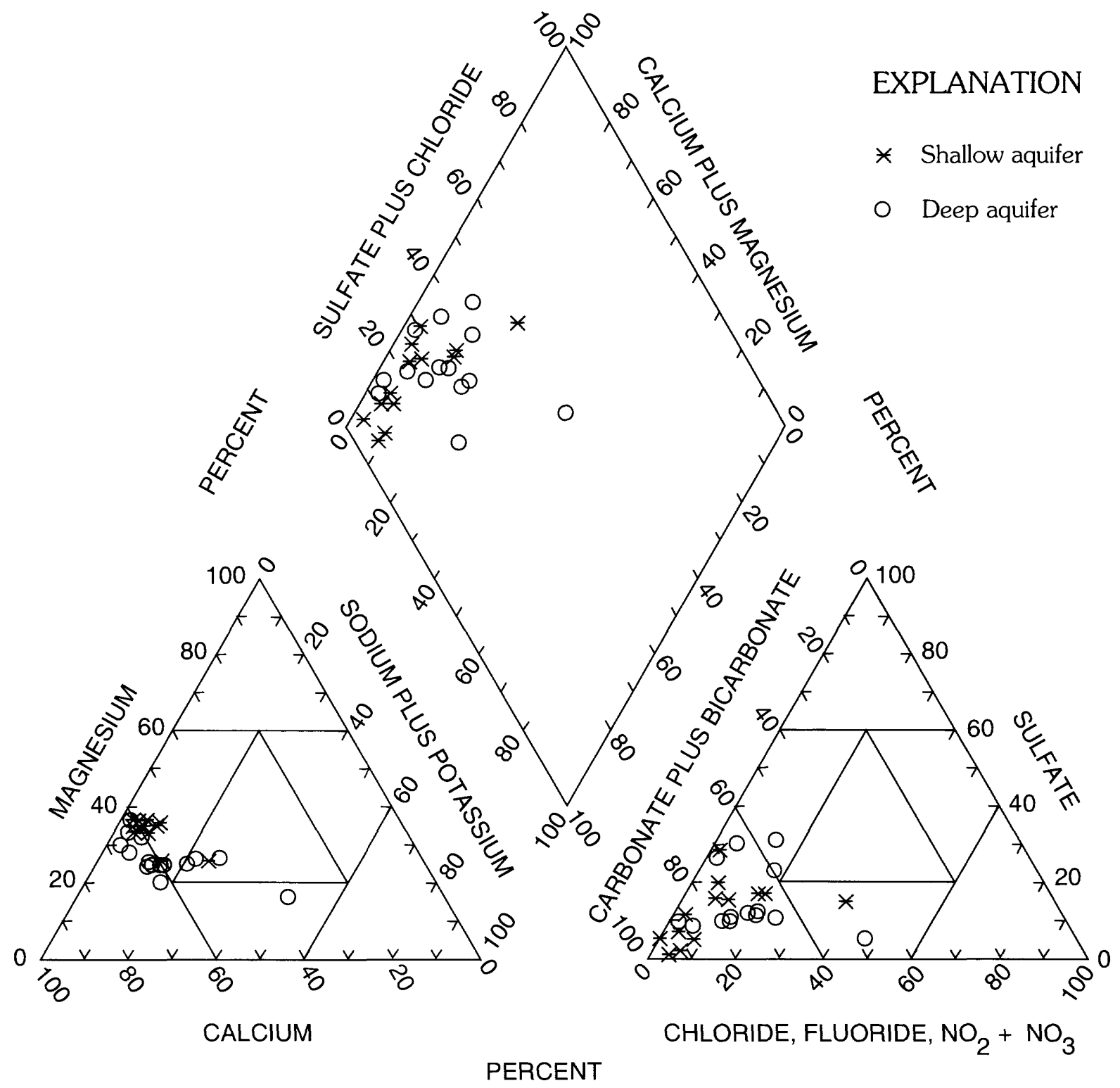

Figure 6. Distribution of major ions in the shallow aquifer and the deep aquifer, northeastern St. Joseph County, Indiana. 


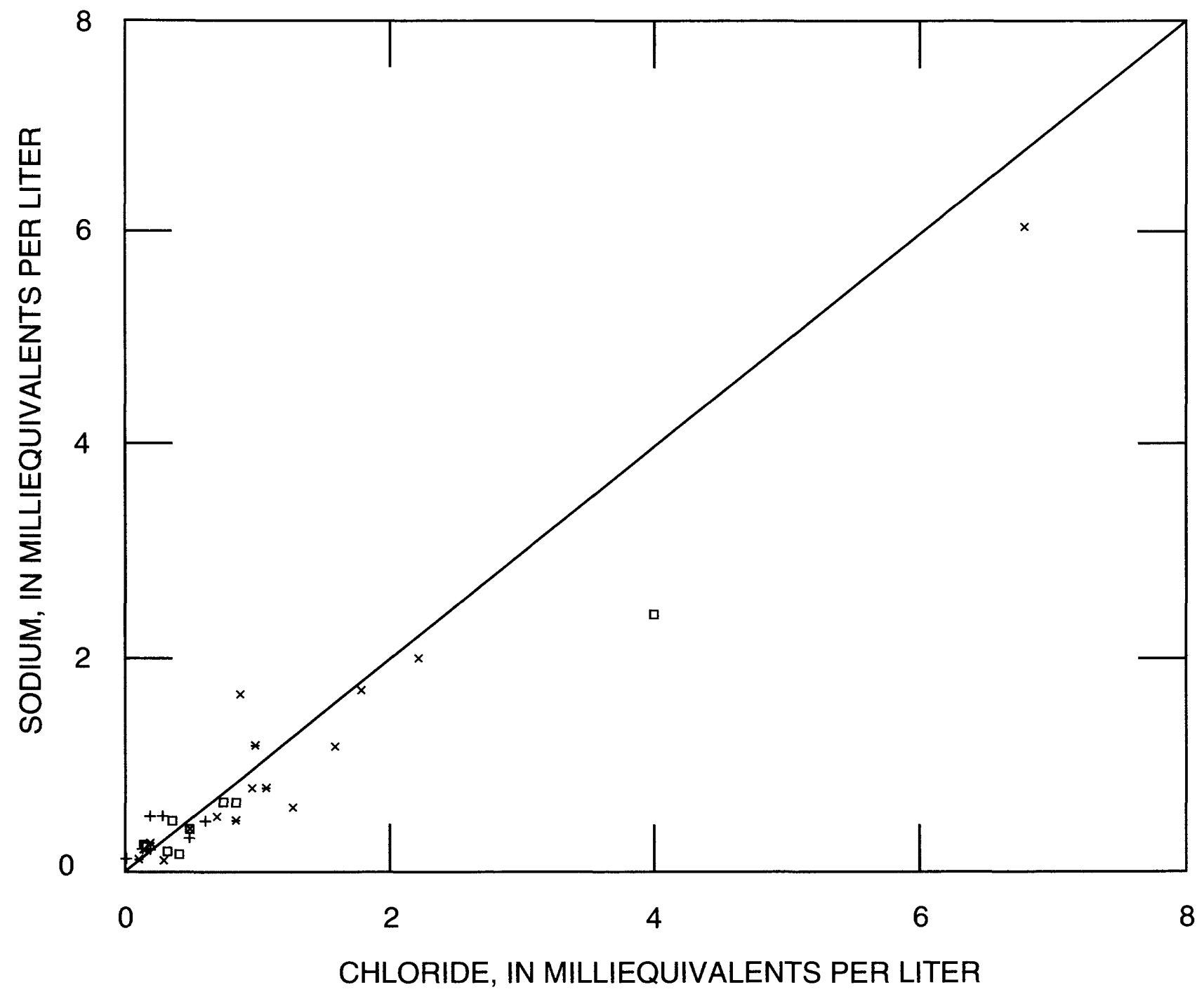

\section{EXPLANATION}

$+\quad$ Deep aquifer underlying agricultural land use

․ Deep aquifer underlying urban and mixed land use

* Shallow aquifer underlying agricultural land use

$\times \quad$ Shallow aquifer underlying urban and mixed land use

Figure 7. Relation of sodium and chloride concentrations to land use and depth, northeastern St. Joseph County, Indiana. 
Median concentrations of all the major constituents except silica were calculated from data from Clendenon and Beaty (1987). Below is a comparison of median concentrations of 34 to 44 water samples from IDNR to the median concentrations of water samples collected from 16 shallow wells and 14 deep wells for this study.

\begin{tabular}{lcccc}
\hline & $\begin{array}{c}\text { IDNR } \\
\text { data } \\
\text { (mg/L) }\end{array}$ & & \multicolumn{2}{c}{$\begin{array}{c}\text { Study data } \\
\text { (mg/L) }\end{array}$} \\
\cline { 2 - 3 } \cline { 5 - 5 } Constituent & $\begin{array}{c}\text { Deep } \\
\text { aquifer }\end{array}$ & & $\begin{array}{c}\text { Deep } \\
\text { aquifer }\end{array}$ & $\begin{array}{c}\text { Shallow } \\
\text { aquifer }\end{array}$ \\
\hline Calcium & 79 & 63 & 88 \\
Magnesium & 27 & & 23 & 22 \\
Sodium & 12 & & 8.4 & 16 \\
Potassium & 1.8 & & .89 & .77 \\
Alkalinity & 248 & 248 & 233 \\
Chloride & 17 & 13 & 32 \\
Sulfate & 55 & 35 & 48 \\
Fluoride & .1 & $<.1$ & $<.1$ \\
\hline
\end{tabular}

Differences between the data from this study and data from IDNR are generally small. Some of the differences may be attributable to differences in laboratory procedures and to changes in water quality caused by pumping. The IDNR data are primarily from water samples collected from watersupply wells with permanent, downhole turbine or submersible pumps, whereas the data for this study are from water samples collected from smalldiameter monitoring wells pumped at low flow rates.

\section{Nutrients}

Water samples were analyzed for six nutrient groups-ammonia ${ }^{3}$, ammonia plus organic

${ }^{3}$ Most of the nitrogen reported as ammonia by the laboratory is present as ammonium in the ground water underlying the study area. nitrogen, nitrite, nitrate plus nitrite, phosphorus, and orthophosphate. Almost all of the nitrate plus nitrite in the water samples was in the form of nitrate (as calculated by subtracting the nitrite concentrations from the nitrate plus nitrite concentrations in table 11). A HA-1 has been drafted for ammonia, and MCL's have been established for nitrite and nitrate; only the MCL for nitrate was exceeded (in two samples).

Differences in ammonia and nitrate plus nitrite concentrations between the shallow aquifer and the deep aquifer were highly significant (table 9, fig. 8). The median concentration of nitrate plus nitrite (as equivalents of nitrogen) in the shallow aquifer was significantly greater than the median concentration in the deep aquifer, $2.5 \mathrm{mg} / \mathrm{L}$ and less than $0.005 \mathrm{mg} / \mathrm{L}$. The median concentration of ammonia (as equivalents of nitrogen) in water samples from the shallow aquifer and the deep aquifer were $0.007 \mathrm{mg} / \mathrm{L}$ and $0.066 \mathrm{mg} / \mathrm{L}$, respectively. Ammonia was generally the primary form of nitrogen in the deep aquifer, and nitrate was generally the primary form of nitrogen in the shallow aquifer. In addition, the median concentration of total nitrogen (in the forms of nitrate, nitrite, and ammonia) in the shallow aquifer was 28 times that in the deep aquifer.

The higher nitrate concentrations in the shallow aquifer and higher ammonia concentrations in the deep aquifer can be explained as follows. Nitrate in the shallow ground water is derived primarily from nitrogen fertilizers (Hallberg, 1989). In some environments, as the nitrate is transported from the shallow aquifer into the deep aquifer, bacteria reduce the nitrate $\left(\mathrm{NO}_{3}\right)$ to nitrous oxide $\left(\mathrm{N}_{2} \mathrm{O}\right)$ or molecular nitrogen $\left(\mathrm{N}_{2}\right)$ through a process called denitrification. 


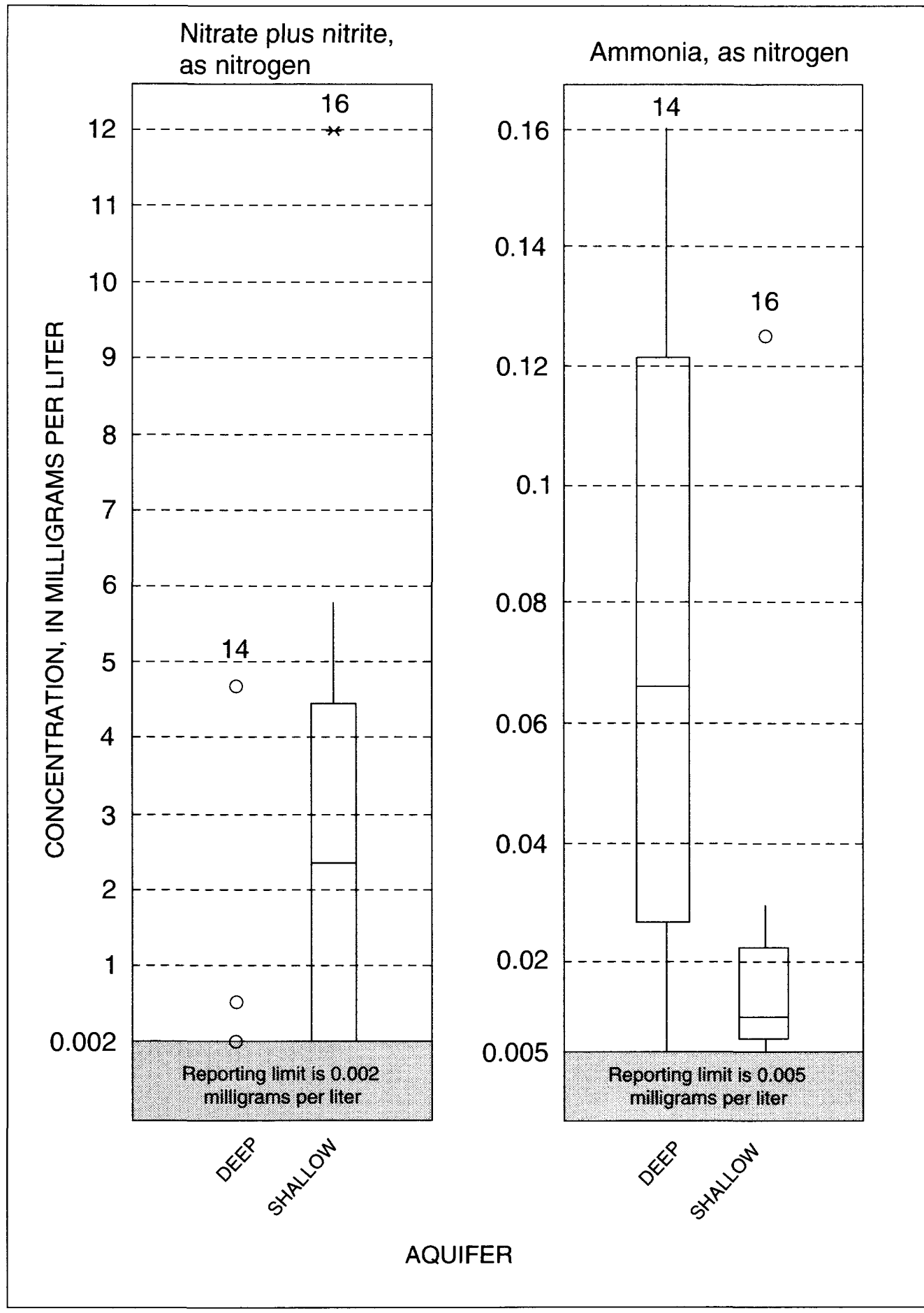

Figure 8. Relations of concentrations of nitrate plus nitrite and ammonia to well depth, northeastern St. Joseph County, Indiana. (The number of measurements is shown at the top of each plot.) 
Denitrification occurs when dissolvedoxygen concentrations become depleted, initiating anaerobic metabolism by bacteria that use nitrate as an oxidizing agent. Dissolved-oxygen concentrations are significantly lower in the deep aquifer than in the shallow aquifer. Therefore, low concentrations of nitrate are expected in the deep aquifer where denitrification is more likely to occur.

Ammonia concentrations that are higher in the deep aquifer than in the shallow aquifer may result from a process termed "dissimilatory nitrate reduction to ammonium" (DNRA) (Korom, 1992). DNRA is a bacterially mediated process whereby nitrate is reduced to ammonium. Denitrification and DNRA are competing processes; DNRA may be favored where nitrate supplies are limited, whereas denitrification may be favored where carbon supplies (as dissolved organic carbon or carbon dioxide) are limited (Korom, 1992, p. 1659).

No relation was evident between nitrate concentrations in the water samples from the shallow aquifer and land use overlying the aquifer. When water samples from the shallow aquifer with more than $0.2 \mathrm{mg} / \mathrm{L}$ of nitrate ${ }^{4}$ were categorized with respect to land use, the rates of occurrence were 40 percent ( 2 of 5 ) in the agricultural landuse area, 75 percent ( 6 of 8 ) in the mixed agricultural and residential land-use area, and 100 percent ( 3 of 3 ) in the urban land-use area. Seven of the water samples in the shallow aquifer had concentrations of nitrate ${ }^{4}$ exceeding $3.0 \mathrm{mg} / \mathrm{L}$. The likely explanation for the occurrence of nitrate in all three land-use areas is that nitrogen fertilizers are used on lawns as well as on farm fields. Nitrate contamination also can result from septic-tank effluent and animal waste.

\footnotetext{
${ }^{4} \mathrm{~A}$ concentration of nitrate less than $0.2 \mathrm{mg} / \mathrm{L}$ is considered to be natural or background, a concentration between 0.2 and $3.0 \mathrm{mg} / \mathrm{L}$ is considered to be transitional, and a concentration greater than $3.0 \mathrm{mg} / \mathrm{L}$ is considered to be the result of human activity (Madison and Brunett, 1984).
}

Concentrations of dissolved phosphorus in natural waters are generally no more than a few tenths of a milligram per liter (Hem, 1985, p. 126). The median dissolved-phosphorus concentration in the samples collected for this study was $0.011 \mathrm{mg} / \mathrm{L}$, and the maximum concentration was $0.11 \mathrm{mg} / \mathrm{L}$ (table 8). Most of the phosphorus is in the form of orthophosphate.

\section{Trace Elements and Cyanide}

Water samples were analyzed for 21 trace elements and cyanide. Of the 21 trace elements, 5 (beryllium, cobalt, copper, nickel, and vanadium) were not detected in any sample, 5 (aluminum, cadmium, chromium, lead, and molybdenum) were detected in only 1 sample, and 2 (mercury and selenium) were detected in 2 samples. The remaining 9 trace elements were detected in a minimum of 6 water samples (antimony) to a maximum of 30 water samples (strontium) (table 8). Cyanide was not detected in any sample.

Some type of Drinking Water Regulation or Health Advisory has been proposed for cyanide and all of the trace elements except cobalt and lithium. Only antimony, iron, and manganese were found at concentrations that exceeded Drinking Water Regulations or Health Advisories (tables 3 and 11). Concentrations of antimony exceeded the HA-1 of $3 \mu \mathrm{g} / \mathrm{L}$ in a sample from well 5-133 $(4 \mu \mathrm{g} / \mathrm{L})$ and were the same as the HA-1 in wells 5-70 and 8-148; all three of these wells produce water from the deep aquifer. Concentrations of iron and manganese exceeded SMCL's in 11 and 15 of the 30 water samples, respectively. Samples from the deep aquifer had 9 of the 11 iron concentrations that exceeded the SMCL and 11 of the 15 manganese concentrations that exceeded the SMCL. Most of the especially high iron and manganese concentrations probably are caused by the dissolution of naturally occurring iron- and manganese-bearing minerals in the unconsolidated sediments. 
Differences in concentrations of five trace elements-antimony, arsenic, barium, iron, and manganese-were highly significant or significant between the shallow aquifer and the deep aquifer, concentrations of these trace elements were higher in the deep aquifer (table 9; fig. 9). The underlying shale is the probable source for the relatively high concentrations of trace elements in the deep aquifer. The New Albany Shale-the Illinois Basin equivalent of the Antrim Shale which underlies the Ellsworth Shale in the study area-is known to have beds that contain high concentrations of trace elements (Leininger, 1981; Ripley and others, 1990). The amount of direct influence the underlying shale bedrock has on the water quality in the deep aquifer is unclear. This influence may be minimal if circulation of ground water between the rock unit and the deep aquifer is minimal. The shale bedrock is more likely to be an indirect influence on the water quality as a result of incorporation of shale fragments into the aquifer material. Shale gravel deposits are not uncommon in northern Indiana (Fraser and Bleuer, 1991) and may be more predominant in the lower aquifer near their bedrock source.

The source of high arsenic concentrations in a deep unconsolidated aquifer near Wakarusa, Ind., approximately $15 \mathrm{mi}$ southeast of South Bend, was attributed to the chemical weathering of shale fragments in the aquifer (Michael Yarling, Indiana Department of Environmental Management, written commun., 1993). Longer flow paths and residence times of ground water in the aquifer also may explain the higher trace-element concentrations in the deep aquifer where the ground water flows through more types of geologic materials (including the clay-rich confining layer) and has more time to equilibrate with the elements composing the aquifer deposits. In addition, under reducing conditions in the deep aquifer, some elements such as iron and manganese increase in solubility. The low dissolved-oxygen concentrations in the deep aquifer would favor dissolution of these elements from native minerals and grain coatings in the aquifer and into ground water.
Most of the trace elements in the water samples probably result from natural processes. The trace elements chromium, lead, molybdenum, nickel, and selenium were detected in samples from only a small number of wells and at low concentrations. Mercury was detected in samples from two wells-1-85 and 5-70 - at concentrations of $1.5 \mathrm{mg} / \mathrm{L}$ and $0.7 \mathrm{mg} / \mathrm{L}$, respectively, (table 11 , at back of report). Each of these wells was the middle-depth well at a site having three nested wells (table 1). The source of mercury is unknown. The source of the trace elements could be human contamination, but most of the detections are probably from naturally occurring trace elements in the unconsolidated sediments.

\section{Organic Constituents}

Water samples collected for this study were analyzed for 151 organic compounds. These compounds, which are on the USEPA list of organic "priority pollutants," include base/neutraland acid-extractable semivolatile organic compounds, volatile organic compounds, pesticides, polychlorinated biphenyls (PCB's), and polychlorinated naphthalenes (PCN's).

\section{Industrlal Organic Compounds}

Previous studies have found benzene, trichloroethane, tetrachloroethylene, phenol, and formaldehyde in the ground water underlying South Bend, Mishawaka, and Granger (Freeman, 1980 , p. 62-64). Organic compounds were detected in well water from four community ground-water systems in the study area during 1981-89 (Indiana Department of Environmental Management, 1989, p. 242). Potential sources of industrial organic compounds in the ground water underlying the study area include landfills, waste lagoons, sludge ponds, septic tanks, aboveground and underground petroleum storage tanks, pipelines, and various active and former industries (Michiana Area Council of Governments, 1989). Ground water in areas of suspected or documented industrial contamination was not sampled. 


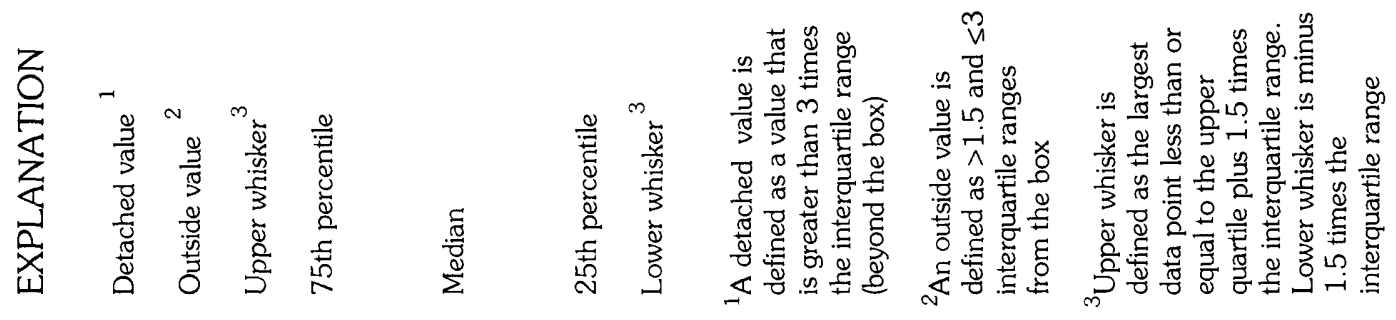
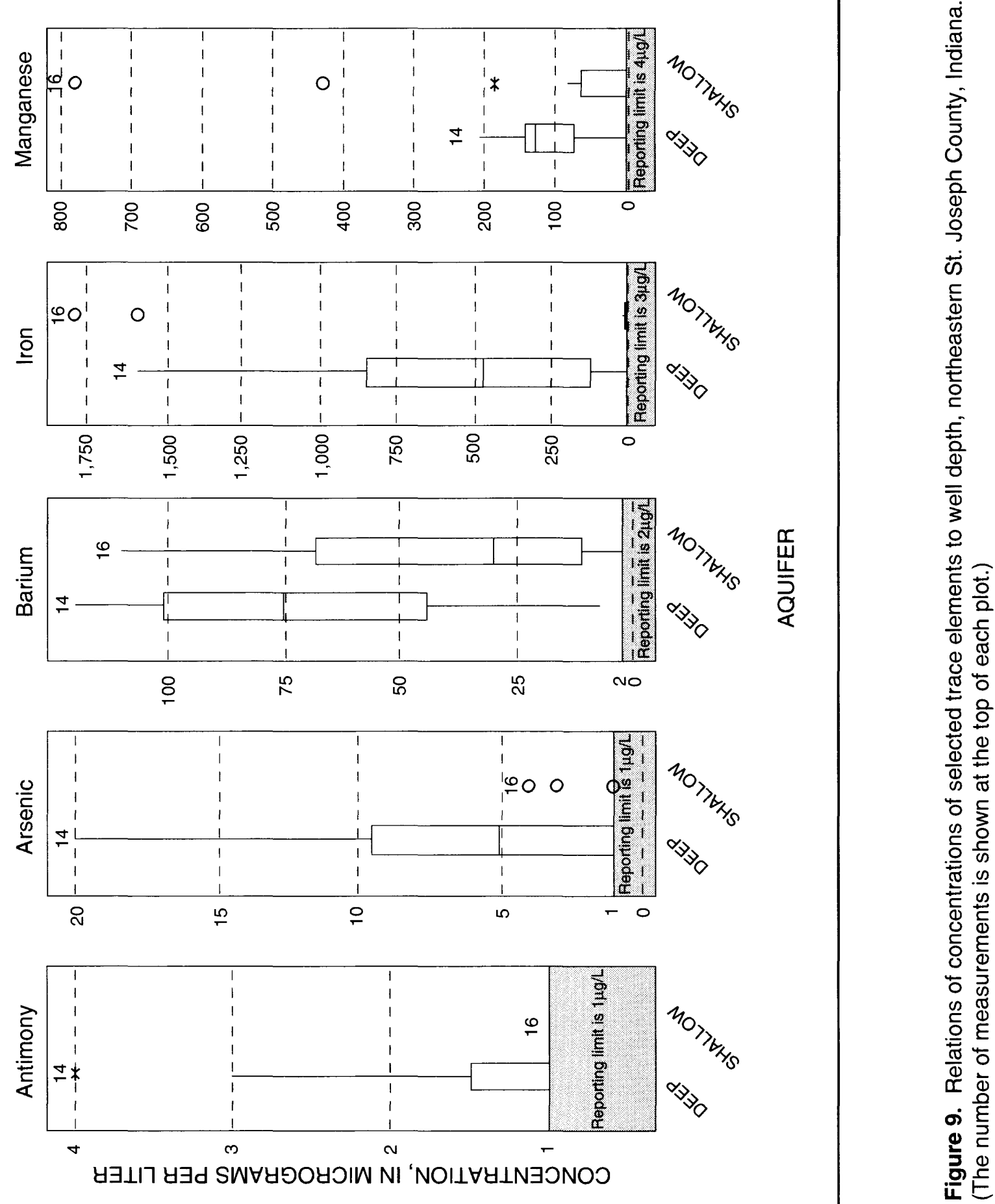
The 57 base/neutral- and acid-extractable semivolatile organic compounds that were sampled for in this study are listed in table 4; PCB's and PCN's also are listed in table 4 . The 62 volatile organic compounds (six of which also are listed with the semivolatile organic compounds) that were examined with GC/MS at the NWQL (wells 5-33, 5-70, 5-133, 23-55, and 27A-148) are listed in table 6. Analysis of volatile organic compounds in water samples from the remaining 25 wells listed in table 1 was semiquantitatively examined with PGC (see "Methods" section).

None of the industrial organic compounds, listed in tables 4 and 6, was detected in the groundwater samples. Reporting limits for many of the industrial organic compounds are well below USEPA Drinking Water Regulations and Health Advisories (tables 4 and 6). The absence of detectable industrial organic compounds in the water samples is evidence that large parts of the shallow and deep aquifers are virtually free of organic contaminants.

\section{Pesticldes}

Twenty-five pesticides and one pesticide family sampled for this study are listed in table 5 . The pesticides include 15 organochlorine insecticides, characterized by their persistence in the environment (Meister, 1989); 7 organophosphorus insecticides (diazinon, ethion, malathion, methyl parathion, methyl trithion, parathion, and carbophenothion [trithion]); 2 nitrogen-containing herbicides (alachlor and metolachlor); a carbamate insecticide (carbofuran); a chlorophenoxy acid herbicide (2,4-D); and a triazine screen of 10 triazine-based herbicides detectable at concentrations of 0.1 to $1.1 \mu \mathrm{g} / \mathrm{L}$.

Approximately 51 percent of the study area was cropland in 1982 (Clendenon and Beaty, 1987, appendix 2). Corn and soybeans are the primary crops grown in the study area. The primary agricultural chemicals used for these crops in 1991 were compiled by Indiana Agricultural Statistics Service (1992) and are summarized below. Herbicides and insecticides were applied to 98 and 27 percent, respectively, of the corn acreage in northern Indiana. In addition, herbicides were applied to 96 percent of the soybean acreage in northern Indiana, whereas insecticides were applied to 1 percent of the soybean acreage in all of Indiana. Chemicals used to treat at least 20 percent of the corn acreage in northern Indiana are atrazine (93 percent), alachlor (46 percent), metolachlor (26 percent), and cyanazine ( 20 percent). In addition, corn acreage received greater quantities of each of these chemicals, by weight, than any other pesticide. All four of these chemicals were sampled in this study. Chemicals used to treat at least 20 percent of the soybean acreage in northern Indiana are metribuzin ( 34 percent), chlorimuronethyl (32 percent), metolachlor (27 percent), and alachlor (26 percent); more pounds of alachlor and metolachlor were applied to soybean acreage than any other pesticide.

Three pesticides (alachlor, carbofuran, and metolachlor) and one pesticide family (triazines) were detected in water samples from the study area (table 10). None of the pesticide concentrations exceeded USEPA Drinking Water Regulations or Health Advisories (table 5). In 13 water samples, at least one pesticide was detected. Metolachlor was detected in the most wells (seven), although well 30-148 was the only well where metolachlor was found above the reporting limit. Alachlor was detected in five wells and at the highest concentrations (as great as $1.0 \mu \mathrm{g} / \mathrm{L}$ ) of any of the pesticides. Carbofuran and triazines were detected once each.

A few observations can be made about the relation of land use and depth to the pesticide concentrations. In 64 percent ( 7 of 11) of the water samples from the shallow wells in the agricultural land-use area, a pesticide was detected; this result is not unexpected. In 100 percent ( 3 of 3 ) of the water samples from deep wells in the urban landuse area, however, at least one pesticide was detected. This result is somewhat surprising and may indicate a longer ground-water flow path that originated in an agricultural land-use area. Water samples from deep wells in the agricultural landuse area had the lowest percentage of detections of pesticides ( 9 percent, 1 of 11). 
Table 10. Pesticide concentrations in water from 30 wells in northeastern St. Joseph County, Indiana, sampled in May 1992

[All concentrations are semiquantitative; all concentrations are in micrograms per liter]

\begin{tabular}{|c|c|c|c|c|}
\hline Well & Alachlor & Carbofuran & Metolachlor & Trlazine screen \\
\hline $1-25$ & $<0.1$ & $<0.1$ & $<0.1$ & $<0.1$ \\
\hline $1-85$ & $<.1$ & $<.1$ & $<.1$ & $<.1$ \\
\hline $1-173$ & $<.1$ & $<.1$ & $<.1$ & $<.1$ \\
\hline $2-25$ & 1.0 & $<.1$ & $<.1$ & $<.1$ \\
\hline $2-139$ & $<.1$ & $<.1$ & $<.1$ & $<.1$ \\
\hline $5-33$ & $<.1$ & $<.1$ & $<.1$ & $<.1$ \\
\hline $5-70$ & $<.1$ & $<.1$ & $<.1$ & $<.1$ \\
\hline $5-133$ & $<.1$ & $<.1$ & $<.1$ & $<.1$ \\
\hline $7-35$ & $<.1$ & $<.1$ & $<.1$ & $<.1$ \\
\hline $8-22$ & $<.1$ & $<.1$ & $<.1$ & $<.1$ \\
\hline $3-148$ & $<.1$ & $<.1$ & $<.1$ & $<.1$ \\
\hline $14-135$ & $<.1$ & $<.1$ & $<.1$ & $<.1$ \\
\hline $16-28$ & .52 & $<.1$ & $<.1$ & $<.1$ \\
\hline $16-173$ & $<.1$ & $<.1$ & $<.1$ & $<.1$ \\
\hline $21-23$ & $<.1$ & $<.1$ & ${ }^{1}<.1$ & $<.1$ \\
\hline $21-133$ & $<.1$ & $<.1$ & $<.1$ & $<.1$ \\
\hline $23-55$ & $1<.1$ & $<.1$ & $<.1$ & $<.1$ \\
\hline $23-133$ & $<.1$ & $<.1$ & ${ }^{1}<.1$ & $<.1$ \\
\hline $25-38$ & $<.1$ & $<.1$ & $<.1$ & $<.1$ \\
\hline $26-30$ & $<.1$ & $<.1$ & ${ }^{1}<.1$ & $<.1$ \\
\hline $27-28$ & $<.1$ & $<.1$ & $<.1$ & $<.1$ \\
\hline $27 \mathrm{~A}-148$ & $<.1$ & $<.1$ & ${ }^{1}<.1$ & $<.1$ \\
\hline $30-29$ & $<.1$ & $<.1$ & ${ }^{1}<.1$ & $<.1$ \\
\hline $30-148$ & $<.1$ & $<.1$ & .11 & $<.1$ \\
\hline $32-148$ & .11 & $<.1$ & ${ }^{1}<.1$ & $<.1$ \\
\hline $33-65$ & $<.1$ & $<.1$ & $<.1$ & $<.1$ \\
\hline $34-33$ at $9: 30$ & $<.1$ & $<.1$ & $<.1$ & $<.1$ \\
\hline $34-33$ at $10: 00$ & $<.1$ & $<.1$ & $<.1$ & $<.1$ \\
\hline $34-33$ at $10: 30$ & $<.1$ & $<.1$ & $<.1$ & $<.1$ \\
\hline $35-52$ & $<.1$ & .26 & $<.1$ & $<.1$ \\
\hline $39-25$ & .83 & $<.1$ & $<.1$ & $<.1$ \\
\hline $41-23$ & $<.1$ & $<.1$ & $<.1$ & ${ }^{1}<.1$ \\
\hline
\end{tabular}

${ }^{1}$ Chemical detected, but at concentrations less than 0.1 microgram per liter. 


\section{SUMMARY AND CONCLUSIONS}

Ground-water samples were collected from 30 monitoring wells at 20 sites in northeastern St. Joseph County, Ind., during May 1992; the wells are screened in either a shallow or a deep sand and gravel aquifer. The wells were sited to characterize general water quality, particularly in areas that may be future sites for public-supply well fields or areas where rapid residential expansion will result in increased construction of private wells; known contaminated sites were avoided. Samples were analyzed for general water-quality properties, nutrients, major constituents, trace elements, industrial organic compounds, and pesticides. The list of analytes includes most of the USEPA "priority pollutants."

In general, the ground water is a slightly basic, very hard, calcium bicarbonate or calcium magnesium bicarbonate-type water with a median dissolved-solids concentration of $310 \mathrm{mg} / \mathrm{L}$. The only constituent to exceed a USEPA MCL in the water samples was nitrate (in two samples). The only constituent to exceed a USEPA Health Advisory concentration in the water samples was antimony (in one sample). USEPA SMCL's for dissolved solids, iron, and manganese were exceeded in 5,13 , and 15 water samples, respectively.

Concentrations of dissolved oxygen, methylene-blue-active substances, chloride, and nitrate plus nitrite in the shallow aquifer were significantly higher (at the $\mathbf{0 . 0 5}$ probability level) than in the deep aquifer. High concentrations of all of these constituents, except oxygen, in the shallow aquifer may be attributable to human activities. Concentrations of silica, ammonia, arsenic, antimony, barium, iron, and manganese in the deep aquifer were significantly higher than in the shallow aquifer, with the exception of ammonia, probably most or all of these constituents are from natural sources.

No industrial organic compounds were detected in the water samples. Four pesticidesalachlor, carbofuran, metolachlor, and triazineswere detected in water samples. In 13 water samples, at least one pesticide was detected; the highest pesticide concentration was $1.0 \mu \mathrm{g} / \mathrm{L}$ of alachlor. 


\section{REFERENCES CITED}

Brock, R.D., 1990, A protocol for onsite screening of volatile organic compounds using a portable gas chromatograph: U.S. Geological Survey Open-File Report 90-379, 15 p.

Clendenon, C.J., and Beaty, J.E., eds., 1987, Water resource availability in the St. Joseph River Basin, Indiana: Indiana Department of Natural Resources, Division of Water, Water Resource Assessment 87-1, $139 \mathrm{p}$.

Durfor, C.N., and Becker, Edith, 1964, Public water supplies of the 100 largest cities in the United States, 1962: U.S. Geological Survey WaterSupply Paper 1812, 364 p.

Fishman, M.J., and Friedman, L.C., eds., 1989, Methods for determination of inorganic substances in water and fluvial sediments: U.S. Geological Survey Techniques of Water-Resources Investigations, book 5, chap. A1, 545 p.

Fowler, K.K., 1994, St. Joseph River basin, in Fenelon, J.M.; Bobay, K.E.; and others, Hydrogeologic atlas of aquifers in Indiana: U.S. Geological Survey Water-Resources Investigations Report 92-4142, 197 p.

Fraser, G.S., and Bleuer, N.K., 1991, Geologic framework of the aquifers of the Valparaiso Moraine: Indiana Department of Natural Resources, Geological Survey Occasional Paper 59, 8 p.

Freeman, C.R., 1980, Groundwater quality assessment: South Bend, Ind., Michiana Area Council of Governments, $72 \mathrm{p}$.

Goolsby, D.A., Thurman, E.M., Clark, M.L., and Pomes, M.L., 1991, Immunoassay as a screening tool for triazine herbicides in streamsComparison with gas chromatographic-mass spectrometric methods, in Vanderlaan, Martin; Stanker, L.H.; Watkins, B.E.; and Roberts, D.E., eds., Immunoassays for trace chemical analysis: Washington, D.C., American Chemical Society Symposium Series, no. 451, p. 86-99.

Hallberg, G.R., 1989, Nitrate in ground water in the United States, in Follett, R.F., ed., Nitrogen management and ground water protectionDevelopments in agricultural and managed-forest ecology: New York, Elsevier, p. 35-74.
Helsel, D.R., and Hirsch, R.M., 1992, Statistical methods in water resources: New York, Elsevier, $522 \mathrm{p}$.

Hem, J.D., 1985, Study and interpretation of the chemical characteristics of natural water (3d ed): U.S. Geological Survey Water-Supply Paper 2254, $263 \mathrm{p}$.

Hunn, J.D., and Rosenshein, J.S., 1969, Geohydrology and ground-water potential of St. Joseph County, Indiana: Indiana Department of Natural Resources, Division of Water Bulletin 33, $20 \mathrm{p}$.

Imbrigiotta, T.E., and Martin, Angel, Jr., 1981, Hydrologic and chemical evaluation of the ground-water resources of northwest Elkhart County, Indiana: U.S. Geological Survey Water-Resources Investigations Report 81-53, 149 p.

Indiana Agricultural Statistics Service, 1992 , Indiana agricultural report: Lafayette, Ind., Purdue University, Department of Agricultural Statistics, v. 12, SP-3, 5 p.

Indiana Department of Environmental Management, 1989, Indiana 305 (b) report, 1988-89: Indianapolis, Ind., 297 p.

Klaer, F.H., Jr., and Stallman, R.W., 1948, Groundwater resources of St. Joseph County, Indiana, part 1, South Bend area: Indiana Department of Conservation, Division of Water Resources Bulletin 3, 177 p.

Korom, S.F., 1992, Natural denitrification in the saturated zone: Water Resources Research, v. 28 , no. 6 , p. $1657-1668$.

Leininger, R.K., 1981, Inorganic geochemistry, in Hasenmueller, N.R., and Woodard, G.S., eds., Studies of the New Albany Shale (Devonian and Mississippian) and equivalent strata in Indiana: Indiana Department of Natural Resources, Geological Survey, p. 53-61.

Lindgren, H.A., Peters, J.G, Cohen, D.A., and Crompton, E.J., 1985, Hydrologic effects of ground- and surface-water withdrawals in the Milford Area, Elkhart and Kosciusko Counties, Indiana: U.S. Geological Survey Water-Resources Investigations Report 85-4166, 76 p. 


\section{REFERENCES CITED-Continued}

Madison, R.J., and Brunett, J.O., 1984, Overview of the occurrence of nitrate in ground water of the United States, in National Water Summary 1984: U.S. Geological Survey Water-Supply Paper 2275, p. 93-105.

Malott, C.A., 1922, The physiography of Indiana, in Logan, W.N. and others, Handbook of Indiana geology: Indiana Department of Conservation, Division of Geology Publication 21, p. 112-124.

Marie, J.R., 1975, Hydraulic characteristics and water-supply potential of the aquifers in the vicinity of the wastewater treatment plant, South Bend, Indiana: U.S. Geological Survey Water-Resources Investigations 49-74, $26 \mathrm{p}$.

Meister, R.T., ed., 1989, Farm chemicals handbook: Willoughby, Ohio, Meister Publishing Company, $670 \mathrm{p}$.

Michiana Area Council of Governments, 1989, St. Joseph County, potential groundwater contamination sites: South Bend, Ind., 1 sheet.

Peters, J.G., 1987, Description and comparison of selected models for hydraulic analysis of ground-water flow, St. Joseph River Basin, Indiana: U.S. Geological Survey WaterResources Investigations Report 86-4199, $125 \mathrm{p}$.

Peters, J.G., and Renn, D.E., 1988, Effects of agricultural irrigation on water resources in the St. Joseph River Basin, Indiana, and implications for aquifer yield: U.S. Geological Survey Water-Resources Investigations Report 87-4273, 35 p.

Pettijohn, R.A., 1968, Reconnaissance of the ground-water resources of the St. Joseph River Basin in Indiana-Appendix to the State water plan: Indiana Department of Natural Resources, Division of Water, $32 \mathrm{p}$.

Piper, A.M., 1953, A graphic procedure in the geochemical interpretation of water analyses: U.S. Geological Survey GroundWater Note $12,14 \mathrm{p}$.
Pritt, J.W., and Raese, J.W., eds., 1992, Quality assurance/quality control manual, National Water Quality Laboratory: U.S. Geological Survey Open-File Report 92-495, 33 p.

Reussow, J.P., and Rohne, P.B., Jr., 1975, Water resources of the St. Joseph River Basin in Indiana: U.S. Geological Survey Hydrologic Investigations Atlas HA-537, scales 1:500,000 and 1:250,000, 3 sheets.

Ripley, E.M.; Shaffer, N.R.; and Gilstrap, M.S., 1990, Distribution and geochemical characteristics of metal enrichment in the New Albany Shale (Devonian-Mississippian), Indiana: Economic Geology, v. 85, p. 1790-1807.

Rosenshein, J.S., and Hunn, J.D., 1962, Groundwater resources of northwestern IndianaPreliminary report, St. Joseph County: Indiana Department of Conservation, Division of Water Resources Bulletin 15, 318 p.

Schneider, A.F., and Keller, S.J., 1970, Geologic map of the $1^{\circ} \mathrm{X} 2^{\circ}$ Chicago Quadrangle, Indiana, Illinois, and Michigan, showing bedrock and unconsolidated deposits: Indiana Department of Natural Resources, Geological Survey, scale $1: 250,000$.

Shaver, R.H.; Ault, C.H.; Burger, A.M.; Carr, D.D.; Droste, J.B.; Eggert, D.L.; Gray, H.H.; Harper, Denver; Hasenmueller, N.R.; Hasenmueller, W.A.; Horowitz, A.S.; Hutchison, H.C.; Keith, B.D.; Keller, S.J.; Patton, J.B.; Rexroad, C.B.; and Wier, C.E., 1986, Compendium of Paleozoic rock-unit stratigraphy in Indiana-A revision: Indiana Department of Natural Resources, Geological Survey Bulletin 59, 203 p.

U.S. Environmental Protection Agency, 1992, Drinking water regulations and health advisories: Washington, D.C., U.S. Environmental Protection Agency, Office of Water, $13 \mathrm{p}$.

Wershaw, R.L.; Fishman, M.J.; Grabbe, R.R.; and Lowe, L.E., 1987, Methods for the determination of organic substances in water and fluvial sediments: U.S. Geological Survey Techniques of Water-Resources Investigations, book 5 , chap. A3, 80 p. 
SUPPLEMENTAL DATA 


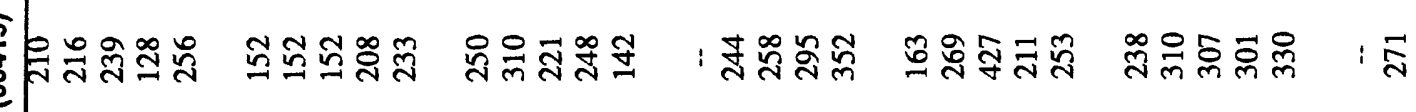
EO EO

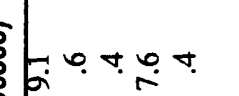

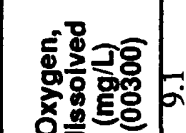
$\stackrel{m}{-\rightarrow} \underset{\sim}{m} \stackrel{\infty}{i}$

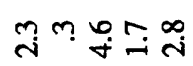

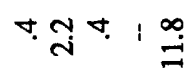
บั่งัง

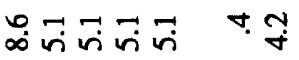

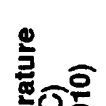

bnooo

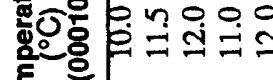

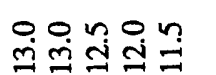
กำำํํำํํำ

nำn 욲ํํำก ตำํำํํำ

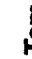

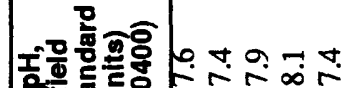

กำ $\infty+m \infty$ ดำ

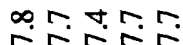

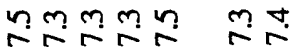
픔

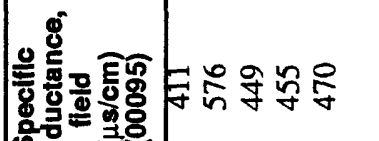
号寻寻守管

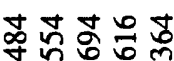

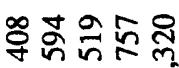

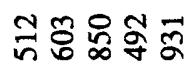
की

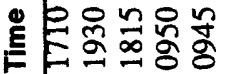

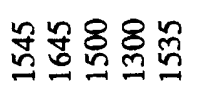

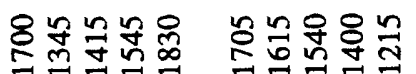

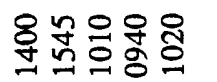
음융임윰윰 음

Kลสํำ \&

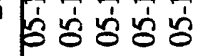
สูสสูสูส ㅇํㅇㅇํ웜

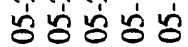

สูกสสำ วิํํㅇํำ

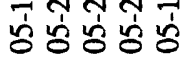

즞ํำ ล่งั่ง ถุ่์ ข้อ

조ํํํํํำ

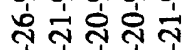

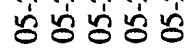

สํํํํำส สำ

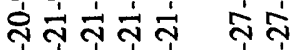

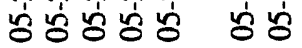

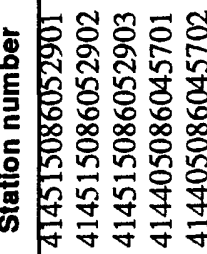

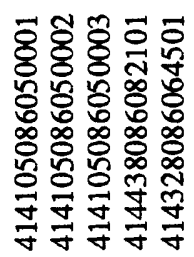
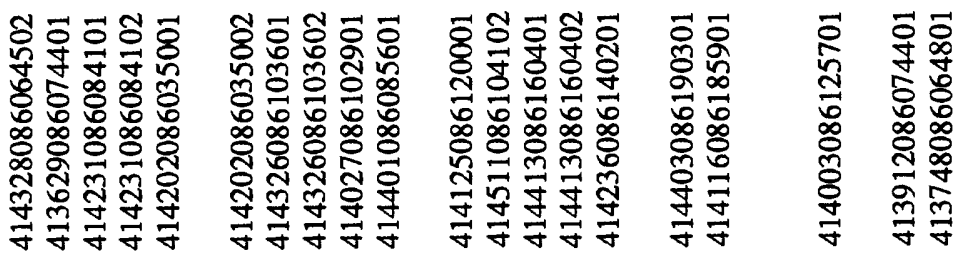

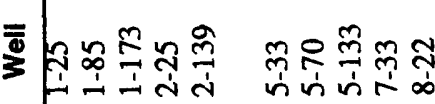

疋 총ㅇㄹㄹ

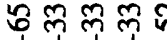
लें सें से ले
ฟุ ชิ $\overrightarrow{7}$ 
|

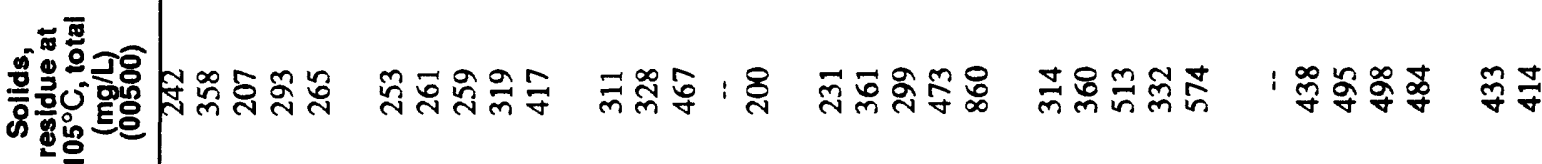

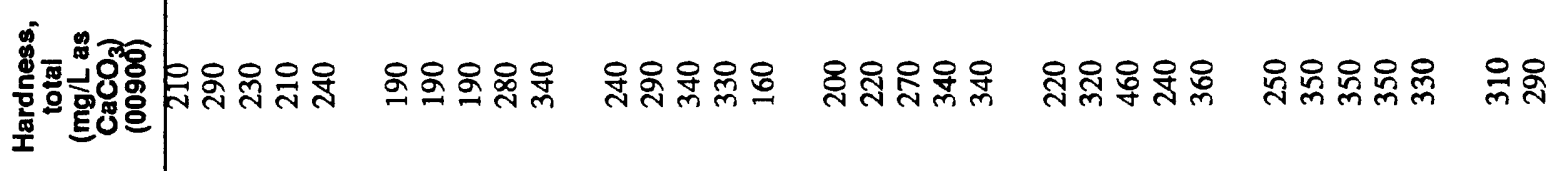
के

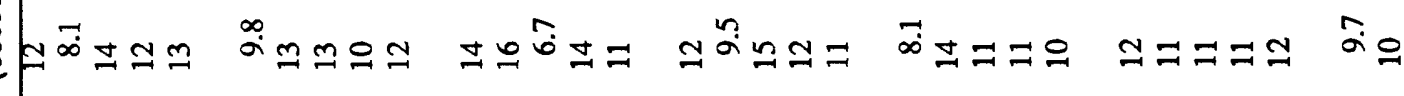

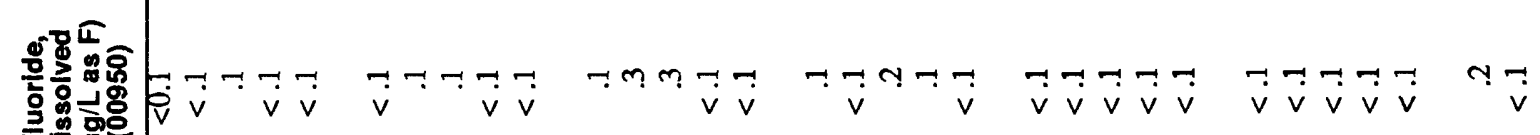

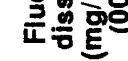
ले

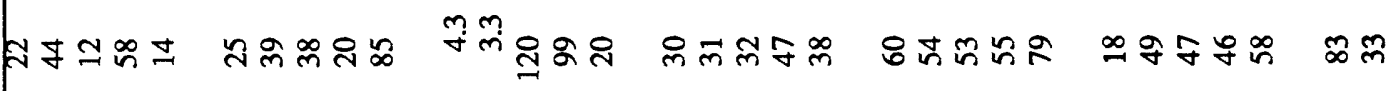

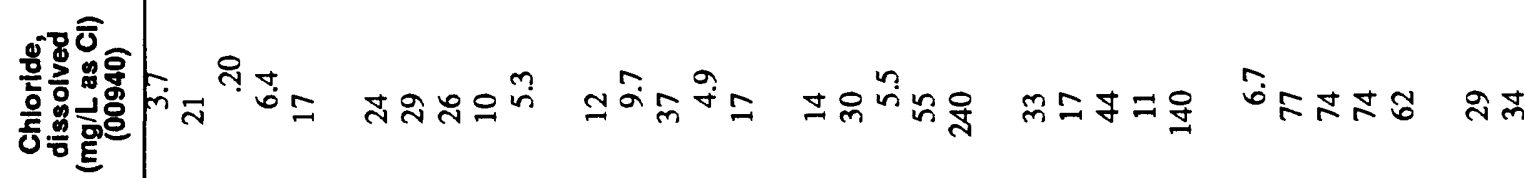

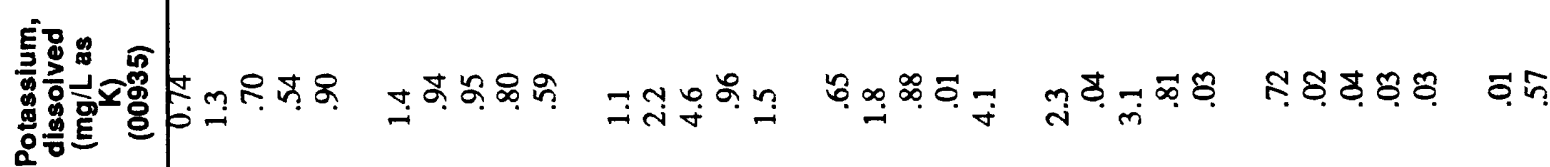

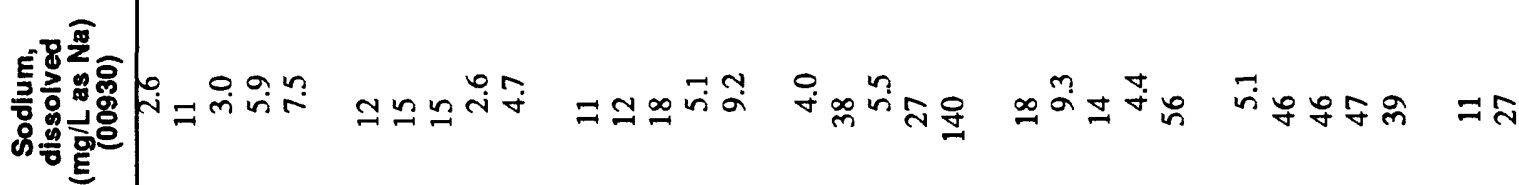
E्zo 高

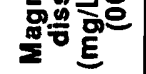

胥星

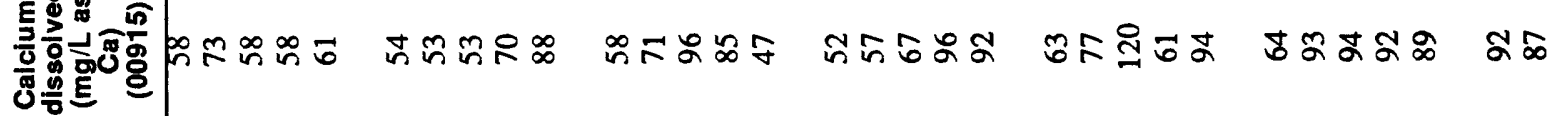

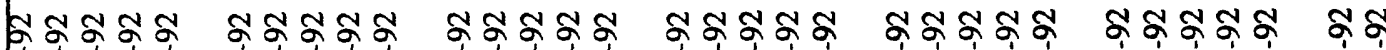

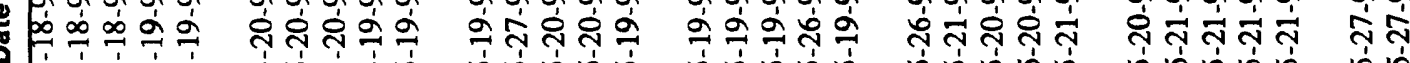
की

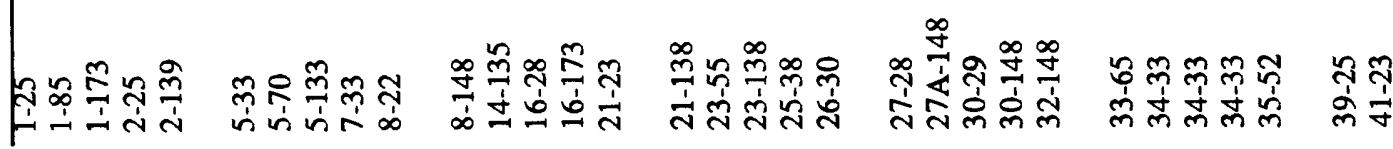




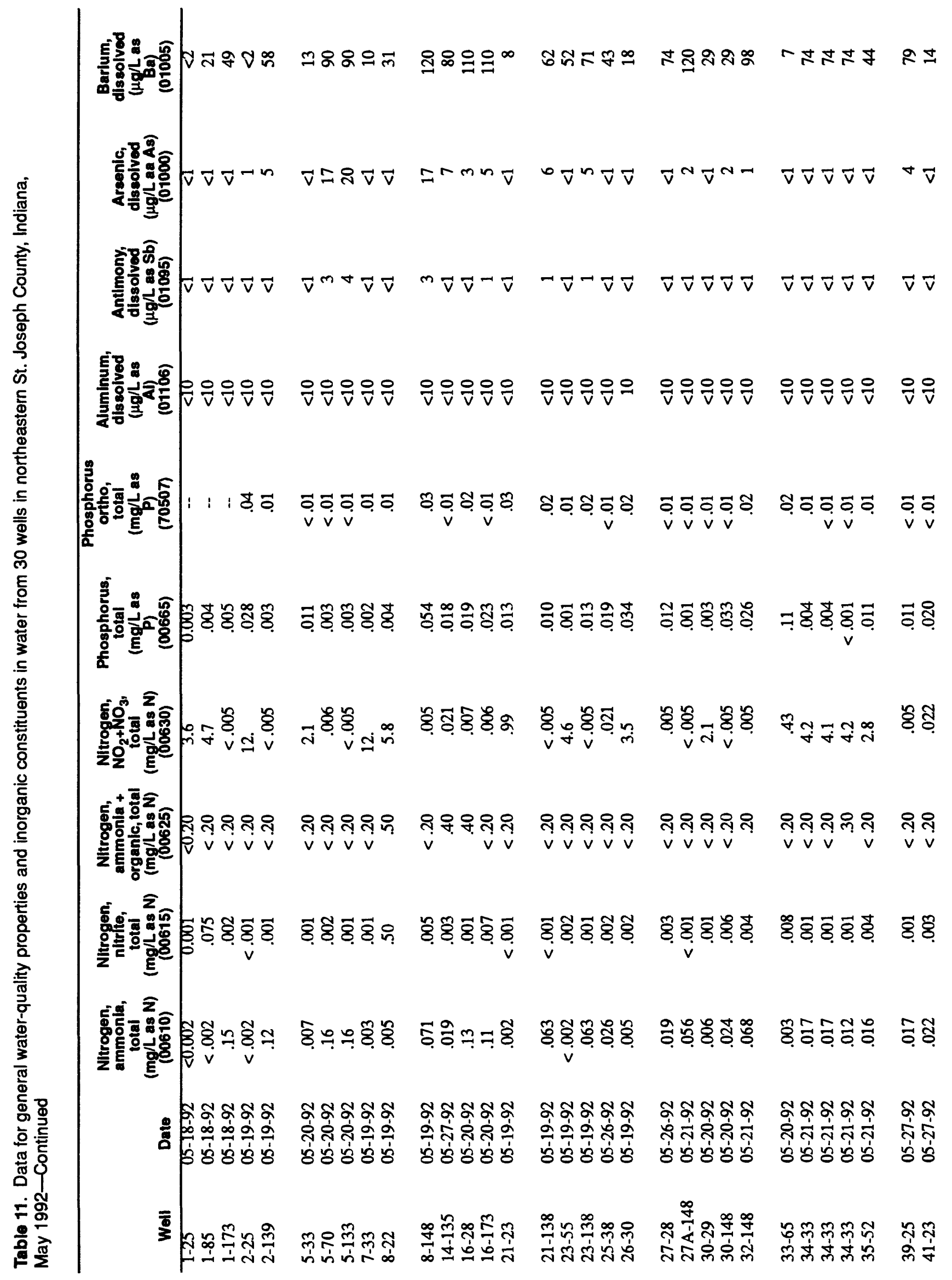




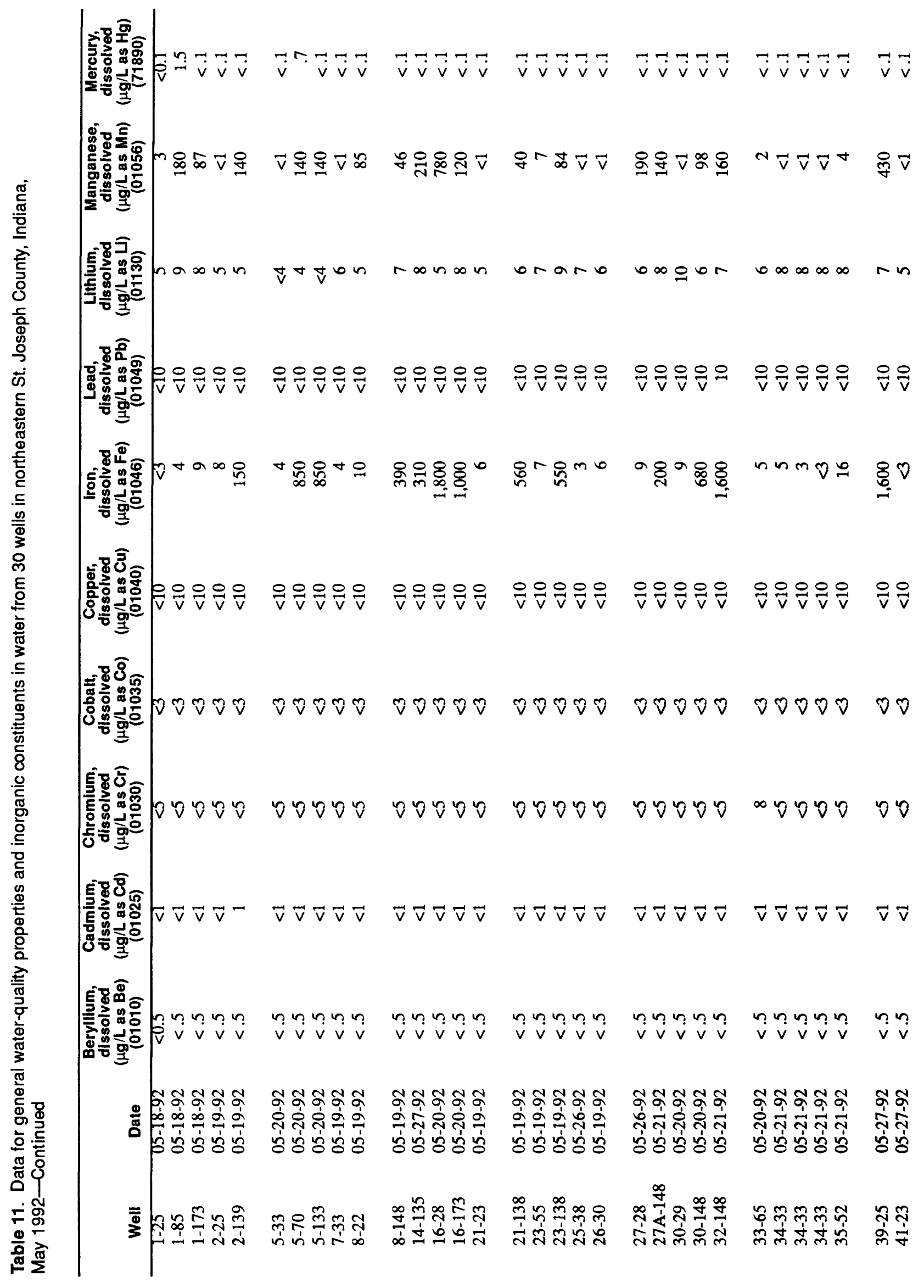




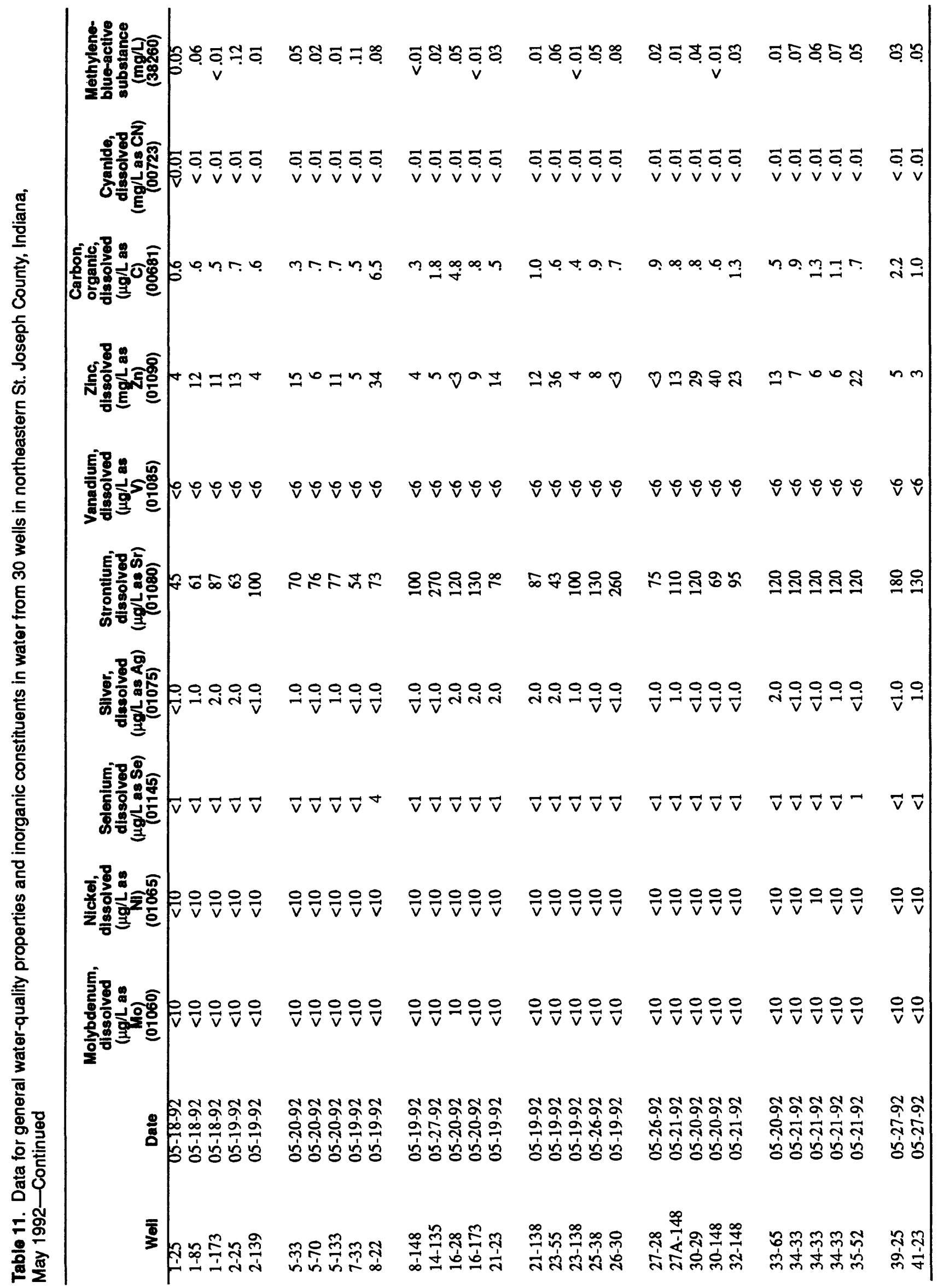

